LONDOÑO, Fernando “QQué prohíben los artículos 52 y 53 de la Ley de Mercado

de Valores? Reconstrucción dogmática de las figuras de manipulación de mercado en el derecho chileno".

Polít. crim. Vol. 12, № 24 (Diciembre 2017), Art. 13, pp. 1106-1183. [http://www.politicacriminal.cl/Vol_12/n_24/Vol12N24A13.pdf]

\title{
¿Qué prohíben los artículos 52 y 53 de la Ley de Mercado de Valores? Reconstrucción dogmática de las figuras de manipulación de mercado en el derecho chileno
}

\section{What do articles 52 and 53 of the Securities Market Act ban? Dogmatic reconstruction of the stock market manipulation figures in Chilean law}

\author{
Dr. Fernando Londoño Martínez \\ Profesor Asociado de la Facultad de Derecho de la Universidad Diego Portales. \\ fernando.londono@udp.cl
}

\section{Resumen}

El trabajo busca clarificar el alcance de los arts. 52 y 53 de la Ley de Mercado de Valores $\mathrm{N}^{\circ} 18.045$ (bajo su Título VIII "Conductas Prohibidas"). Las dificultades hermenéuticas que plantea el Título VIII habían sido ya abordadas por el autor en esta misma revista (Londoño, F., “Aproximación histórico-comparada [...]”, Polit. Crim., 2015), fundamentalmente en base a un método comparatista y obteniendo resultados delineados, pero todavía puramente esquemáticos. En este artículo se profundiza aquel análisis, recurriendo ahora a fuentes de derecho interno: reglamentos e instrumentos de

\footnotetext{
* Como se explica con detalle en el epílogo, este trabajo completa un esfuerzo hermenéutico progresivo, marcado por dos publicaciones anteriores, siempre en esta misma Revista: primero en 2013 (LONDOÑO, "Ilícito de manipulación [...]", cit. nota n ${ }^{\circ}$ 2) y luego en 2015 (Londoño, "Aproximación histórico-comparada [...]", cit. nota $\left.{ }^{\circ} 1\right)$. La tercera pieza de este iter se publica ahora, en el marco del Proyecto Fondecyt Regular $\mathrm{N}^{\circ}$ 1160636, años 2016-2019, del que soy investigador principal. Aspectos centrales de las tesis aquí defendidas fueron detalladamente discutidas en el workshop Fondecyt "La punibilidad de la falsedad informativa en el Mercado de Valores II" (U. Andes, 13 diciembre de 2016), organizado junto al colega Gonzalo García Palominos (en su caso con cargo al Proyecto Fondecyt N$^{\circ} 11140444$; en mi caso con motivo del ya aludido proyecto Fondecyt). Aquel seminario dio lugar a una discusión tan intensa como cordial, que sólo fue posible gracias a la generosidad de los expositores y moderadores, colegas Antonio Bascuñán R., Patricia Faraldo, Juan Pablo Mañalich, Héctor Hernández, Luis Emilio Rojas, Jaime Vera y Javier Wilenmann, además del propio Gonzalo García Palominos, naturalmente. El valor más profundo de una comunidad académica cobró allí todo su sentido para mí. Debido es mencionar, además, que una parte muy significativa de los contenidos del presente trabajo fueron desarrollados a partir de tres encargos profesionales, comenzando en enero de 2015 y culminando en octubre de 2016, dos meses antes del workshop. Reelaboré luego partes del material, ampliando o complementando lo pertinente (especialmente en la sección 2.2.1, a propósito del mercado OTC y bursátil de derivados; en el excurso de la sección 2.4.1.a]; o en la sección 2.4.1.d], junto con la inclusión de nueva literatura e innumerables cambios formales), hasta el punto de parecerme eventualmente adecuado para someterlo a evaluación en este medio, a contar de mayo de 2017 (en sede de revisión final pude además actualizar el trabajo con publicaciones nacionales aparecidas entre julio y agosto de 2017). Aspectos de esa reelaboración se vieron en fin favorecidos por una breve estancia de investigación en la Hugh and Hazel Darling Law Library de la UCLA Law School, en enero de 2017. En ese contexto tuve la oportunidad de beneficiarme de un valioso intercambio de puntos de vista con el profesor James J. Park, a quien quisiera agradecer especialmente. Por la gentil acogida en aquel contexto californiano debo además agradecimientos a Kevin Gerson, Keith Boseman, Shangching Huitzacua y a los profesores Sung Hui Kim y Máximo Langer. Agradecimientos por último para el colega Mario Catalán, por su colaboración en la revisión final del artículo.
} 
LONDOÑO, Fernando “¿Qué prohíben los artículos 52 y 53 de la Ley de Mercado

de Valores? Reconstrucción dogmática de las figuras de manipulación

de mercado en el derecho chileno".

autorregulación de las dos Bolsas de Santiago de Chile, jurisprudencia administrativa y penal, doctrina, historia de la ley. El material examinado toma forma en una completa reconstrucción dogmática del Título VIII, caracterizado por el autor en dos planos: (1) como correlato de una dicotomía taxonómica (ya advertida en Londoño, F., "Ilícito de manipulación [...]", Polit. Crim., 2013) que distingue entre manipulación directa [art. 52] y manipulación indirecta [art. 53]; y (2) como una tríada de fórmulas anti-manipulativas del precio-de-mercado en un sistema regulado de oferta pública de valores, identificando un espacio de (i) regulación para la manipulación operativa propia [art. 52], (ii) prohibición para la manipulación operativa impropia [art. 53 inciso $1^{\circ}$ ] y (iii) prohibición para las demás formas de manipulación indirecta, incluyendo la manipulación informativa y la manipulación de hecho o por vía de actividades engañosas extra bursátiles [art. 53 inciso $2^{\circ}$ ]. El trabajo se cierra con una propuesta hermenéutica lineal - pasaje por pasaje - para las prohibiciones de los arts. 52 y 53 (cuya infracción gatilla también responsabilidad penal bajo el supuesto de la letra e] del art. 59 de la misma ley).

Palabras clave: Artículos 52 y 53 de la Ley de Mercado de Valores (Ley $N^{\circ}$ 18.045), Secciones 9(a) y 10(b) de la Ley Federal de Intercambio de Valores de los EE.UU., Regla 10b-5, Manipulación del mercado de valores, Abuso de mercado y Directiva 6/2003/CE, alteración de precios, inducción a la compra o venta de valores.

\section{Abstract}

The paper aims to clarify the scope of provisions 52 and 53 of the Chilean Securities Market Act (under Title VIII: "Prohibited Conduct"). The author had addressed before the hermeneutic difficulties raised by Title VIII (Londoño, F., "Aproximación históricocomparada [...]", Polit. Crim, 2015), mainly using a comparative approach and obtaining well defined results, although on a purely schematic basis. This paper goes deeper in such analysis, with the use of domestic sources of law: regulation and self-regulation instruments of the Santiago Stock Exchanges, administrative and penal jurisprudence, doctrine, history of the law. The material thus examined crystallizes into a detailed dogmatic reconstruction of Title VIII, characterized by the author as twofold: (1) in correspondence with a taxonomic dichotomy (addressed in Londoño, F., "Ilícito de manipulación [...]", Polit. Crim., 2013) that distinguishes between direct manipulation [provision 52] and indirect manipulation [provision 53]; (2) as a triad of anti-manipulative market-price formulas in a regulated securities market system, thus identifying a space for (i) the regulation of actualtrade-based manipulation [provision 52], (ii) the banning of fictitious-trade-based manipulation [provision $53.1^{\circ}$ ] and (iii) the banning of other kinds of indirect manipulation, including information-based manipulation and action-based manipulation [provision $53.2^{\circ}$. The work closes with a straightforward hermeneutic proposal - passage by passagefor sections 52 and 53 LMV (whose violation triggers criminal liability under section 59 e] LMV).

Key words: Sections 52 and 53 of the Chilean Securities Market Act (Act $\mathrm{N}^{\circ}$ 18.045), Sections 9(a) and 10(b) of the U.S. Securities Exchange Act, Rule 10b-5, Securities market manipulation, Market Abuse and the 2003/6/CE Directive, price tampering, inducement of purchase or sale of securities. 
Polít. crim. Vol. 12, № 24 (Diciembre 2017), Art. 13, pp. 1106-1183.

[http://www.politicacriminal.cl/Vol_12/n_24/Vol12N24A13.pdf]

Sumario. Introducción (síntesis de la tesis defendida). 1. El Título VIII LMV en el contexto normativo local: elementos de derecho interno consistentes con la tesis. 1.1. Génesis normativa: proyecto de LMV, de 30 de diciembre de 1980. 1.2. Pre comprensión del Título VIII en nuestro medio: jurisprudencia administrativa y penal, instancias de autorregulación y doctrina nacional. 1.2.1. Jurisprudencia administrativa y penal. a) Caso MBI. b) Caso Schwager. 1.2.2. Instrumentos de autorregulación del sector. a) Reglamentos de las Bolsas de Valores (Reglamento de la Bolsa de Comercio de Santiago y Reglamento de Operaciones de la Bolsa Electrónica de Chile). b) Manual de Operaciones de la Bolsa de Comercio de Santiago: interferencias anti-competitivas (no manipulativas per se). c) Reglas del Comité de Regulación y Autorregulación de las Bolsas de Comercio de Santiago y Electrónica de Chile, abril de 2009. Reglas para prevenir y combatir el uso de información privilegiada y la manipulación del mercado. 1.2.3. Pronunciamientos doctrinarios. 2. Reconstrucción dogmática del Título VIII LMV: sobre el alcance de los arts. 52 y 53 (a la vez, una propuesta sobre el sentido del art. 61). 2.1. Sentido general de protección del Título VIII LMV. 2.2. Primer planteamiento base: sobre la unidad de propósito general y la relación (complementaria) entre el art. 52 y el art. 53 LMV. 2.2.1. Art. 52 LMV (además de una nota relativa a las manipulaciones en el mercado de derivados). 2.2.2. Art. 53 LMV. 2.3. Segundo planteamiento base: sobre la unidad de propósito y la relación (de especialidad) entre el inc. $1^{\circ}$ y $2^{\circ}$ del art. $53 \mathrm{LMV}$. El alcance del inc. $1^{\circ}$ del art. 53. 2.4. El alcance del inc. $2^{\circ}$ del art. 53 LMV. 2.4.1. Primera modalidad típica del inciso $2^{\circ}$ del art. 53 LMV: efectuar transacciones [...] por medio de cualquier acto, práctica, mecanismo o artificio engañoso o fraudulento. a) ¿"Engañoso o fraudulento"? Excurso: sobre la situación de la injerencia por vías de hecho genéricamente ilícitas o delictivas (no engañosas). b) "Efectuar transacciones": sentido general y cobertura práctica. c) Una aclaración: ¿transacción inducida mediante engaño? o ¿transacción engañosa inductiva? Sentido interno y sentido externo de la primera variante del art. 53 inciso $2^{\circ}$. d) Objeto material: valores objeto de las transacciones. ¿Apertura hacia una figura de engaño público en la solicitud de inversión en valores? 2.4.2. Segunda modalidad típica del inciso $2^{\circ}$ del art. 53 LMV: inducir o intentar inducir a la compra o venta de valores, regidos o no por esta ley, por medio de cualquier acto, práctica, mecanismo o artificio engañoso o fraudulento. a) El sentido manipulativo de la fórmula de inducción a la compra $o$ venta de valores (mediante cualquier acto, práctica, mecanismo o artificio engañoso o fraudulento). b) Alcance: tipologías comprendidas bajo la segunda variante del inciso $2^{\circ}$ del art. 53. c) Lecturas alternativas. c).i. ¿Inducción a comprar o vender valores como "inducción a cometer delitos"? c).ii. Una lectura patrimonialista. 2.5. Tipicidad subjetiva en las figuras penales del Título VIII. 2.6. Sobre el art. 61 LMV y su problemática posición. 3. Lectura lineal del tipo penal del art. 59 e) LMV en relación con los arts. 52 y 53. 3.1. Aspectos generales. Concepto de manipulación y taxonomías implícitas en los arts. 52 y 53 LMV. 3.2. Sub-tipo constituido por el art. 59e)-52 LMV. 3.2.1. Tipo objetivo. 3.2.2. Tipo subjetivo. 3.2.3. Justificante especial. 3.3. Sub-tipo constituido por el art. 59e)-53 LMV. 3.3.1. Art. 53 inc. $1^{\circ}$ LMV. a) Tipo objetivo. b) Tipo subjetivo. c) Justificantes especiales del art. 53 (válido para ambos incisos). 3.3.2. Art. 53 inc. $2^{\circ}$ LMV. a) Tipo objetivo. b) Tipo subjetivo. c) Justificantes especiales. Epílogo. Bibliografía. 
LONDOÑO, Fernando “¿Qué prohíben los artículos 52 y 53 de la Ley de Mercado

de Valores? Reconstrucción dogmática de las figuras de manipulación

de mercado en el derecho chileno".

\section{Introducción (síntesis de la tesis defendida)}

El presente artículo busca esclarecer detalladamente el alcance del Título VIII de la Ley $\mathrm{N}^{\circ} 18.045$ de Mercado de Valores chilena (en adelante LMV), en su relación con el tipo penal de la letra e) del art. 59 LMV. La tarea se ubica en la trayectoria abierta en un trabajo anterior del suscrito ${ }^{1}$, prevalentemente marcado por una metodología comparatista, en la que la interpretación del Título fue anticipada en términos todavía esquemáticos. Con recurso a material de derecho nacional y elaboración dogmática, este artículo completa aquella trayectoria, ampliándola y profundizándola.

Recuérdese que el Título VIII LMV se compone de tres prohibiciones, las que constituyen el núcleo del sub-tipo penal del art. 59-e) LMV; a saber:

a. [Art. 52 inc. $1^{\circ}$ ] "Es contrario a la presente ley efectuar transacciones en valores con el objeto de estabilizar, fijar o hacer variar artificialmente los precios".

b. [Art. 53 inc. $1^{\circ}$ ] "Es contrario a la presente ley efectuar cotizaciones o transacciones ficticias respecto de cualquier valor, ya sea que las transacciones se lleven a cabo en el mercado de valores o a través de negociaciones privadas".

c. [Art. 53 inc. $2^{\circ}$ ] "Ninguna persona podrá efectuar transacciones o inducir o intentar inducir a la compra o venta de valores, regidos o no por esta ley, por medio de cualquier acto, práctica, mecanismo o artificio engañoso o fraudulento".

Varias y relevantes son las interrogantes que estas prohibiciones plantean: ¿a qué estrategia o interés de tutela responden? En otras palabras, ¿se agota su sentido de protección en el reforzamiento de la (confianza en la) correcta formación del precio-de-mercado ${ }^{2}$ o pueden

${ }^{1}$ LONDOÑO, Fernando, "Aproximación histórico-comparada al Título VIII de la Ley de Mercado de Valores: bases para el reconocimiento de un contenido anti-manipulativo", Política Criminal, Vol. 10, № 20 (2015), Art. 1, pp. 390-467.

${ }^{2}$ Como mecanismo coronador de una serie de estrategias económico-jurídicas que persiguen morigerar los efectos negativos (selección adversa) de la asimetría informativa en un sistema de oferta pública de valores. $\mathrm{Al}$ respecto, con detalle, cfr. LONDOÑO, Fernando, "Ilícito de manipulación bursátil: fenómeno y lesividad. Aspectos de política sancionatoria", Política Criminal, Vol. 8, No 15 (2013), Art. 3, pp. 64-127, disponible en: http://www.politicacriminal.cl/Vol 08/n_15/Vol8N15A3.pdf, pp. 74 y ss., especialmente la nota 24, con referencia al indeseable riesgo de selección adversa que plantean los mercados informáticamente asimétricos, hasta el punto de la opacidad. Como es bien sabido, la noción de selección adversa y su asociación a la asimetría informativa se halla en el célebre AKERLOF, George, "The Market for «Lemons»: Quality Uncertainty and the Market Mechanism”, 84 Q. J. Econ. (1970), pp. 488-500. La vinculación de estos conceptos económicos a la problemática de la regulación de los mercados financieros es - en el marco de la atención a las market failures - ampliamente advertida desde el mundo jurídico. Así, de reciente, cfr. ARMOUR, John et Al., Principles of Financial Regulation, New York: Oxford University Press, 2016, pp. 55-57, enfatizando los autores la relevancia de esta perspectiva para el mercado de los productos y servicios financieros, por tratarse allí del intercambio de bienes cuya apreciación o valoración descansa fuertemente en la dimensión de la confianza (credence goods); la confianza en los presupuestos para la correcta formación del precio-de-mercado sería entonces decisiva en este particular mercado. Un enfoque similar puede apreciarse en PERRONE, Andrea, Il diritto del mercato dei capitali, Milano: Giuffrè Editore, 2016, pp. 7-10, 34-35 y 255-256, en este último caso precisamente con referencia a los peligros de un mercado entregado a 


\section{Polít. crim. Vol. 12, No 24 (Diciembre 2017), Art. 13, pp. 1106-1183. [http://www.politicacriminal.cl/Vol_12/n_24/Vol12N24A13.pdf]}

estas prohibiciones considerarse funcionales a la protección de intereses fragmentarios o particulares, no-institucionales? Más concretamente, ¿han de leerse estas disposiciones unitariamente, respondiendo su cobertura a la sola prohibición de formas de manipulación del mercado o pueden acaso entenderse como prohibiciones teleológicamente desarticuladas, con radios de cobertura tan dispares como la contención de formas de estafa de inversión o de administración desleal en perjuicio del patrimonio de inversionistas particulares? En el primer supuesto, ¿qué hipótesis de manipulación de mercado resultan cubiertas y qué aporta en ese contexto el art. 53, especialmente su inciso $2^{\circ}$ ?

Esas preguntas deberían hallar respuestas detalladas en el cuerpo de este trabajo. Ahora bien, si esta introducción ha de tener algún sentido, no puede ser sino el de anticipar el tenor de aquellas respuestas, aunque sea esquemáticamente. Servirá a la vez para retomar y ampliar ligeramente las conclusiones del trabajo que ha antecedido al presente ${ }^{3}$.

Como primera cuestión general, aquí se postula un sentido de antijuridicidad material unitario para el Título VIII LMV. Conforme a esta tesis, los arts. 52 y 53 se explicarían y coordinarían únicamente para dar cobertura a todas las formas de manipulación del mercado de valores conocidas en la literatura y en la praxis. Se descarta por tanto su rendimiento para la prohibición y tipificación de conductas no directamente dirigidas al trastrocamiento del precio-de-mercado.

Con el término manipulación del mercado de valores o manipulación del precio-demercado de valores la literatura especializada describe en general toda conducta ejecutada con la intención de injerir, artificialmente, en el precio-de-mercado de instrumentos financieros transados en un mercado de valores ${ }^{4}$.

abusos (manipulación y uso de información privilegiada). En fin, otra aplicación del análisis a partir de los costos introducidos por la asimetría informativa - ahora en el plano de la formación de precios por los market-makers - puede verse también en el ya citado ARMOUR et Al., Principles, supra cit., pp. 113-114.

${ }^{3}$ Cfr. LONDOÑO, "Aproximación histórico-comparada", cit. nota n ${ }^{\circ} 1$, pp. 459 y ss.

${ }^{4}$ Con fines pedagógicos, introductorios, se propone aquí una definición amplia. Para una definición analítica y detallada cfr. AVGOULEAS, Emilios, The Mechanics and Regulation of Market Abuse. A legal and Economic Analysis, Oxford: Oxford University Press, 2005, p. 116. De reciente, para Europa, muy detalladamente, cfr. MOLONEY, Niamh, EU Securities and Financial Markets Regulation, Oxford: Oxford University Press, 3d. ed., 2014, pp. 703 y ss. Más sintético, siempre para Europa, cfr. ARMOUR et Al., Principles, cit. nota $\mathrm{n}^{\circ}$ 2, pp. 182 y ss., con una interesante nota sobre la diversa terminología para Europa y Estados Unidos (contexto en el que la voz market manipulation comprendería sólo formas de manipulación operativa, mientras que las modalidades informativas quedarían comprendidas por la más amplia noción de secutiries fraud). Para Estados Unidos, ampliamente, cfr. LOSS, Louis; SELIGMAN, Joel; PAREDES, Troy, Fundamentals of Securities Regulation, New York: Wolters Kluwer, 6th. ed., 2011, Vol. 2, Cap. 10, pp. 1485 ss. Igualmente de reciente, para Estados Unidos, cfr. COX, James D.; HILLMAN, Robert W.; LANGEVOORT, Donald C., Securities Regulation. Cases and Materiales, New York: Wolters Kluwer, 8th ed., 2016, pp. 771 ss. En lo demás, para una aproximación al concepto y regulación de la manipulación en distintos contextos históricos y comparados: cfr. BERLE A.A. Jr., "Stock Market Manipulation", Colum. L. Rev., n. 38 (1938), pp. 393 y ss.; PERDUE, Wendy C., "Manipulation of futures markets: redefining the offense", Fordham L. Rev., n. 56 (1987), pp. 345 y ss.; THEL, Steve, "\$ 850,000 in Six Minutes -- The Mechanics of Securities Manipulation", Cornell L. Rev., n.79 (1994), pp. 219 y ss.; PEDRAZZI, Cesare, "Turbativa dei mercati (voce)", Dig.Disc. Pen., (1999), pp. 421-432; SEMINARA, Sergio, "I reati di aggiotaggio", en: PEDRAZZI et Al., Manuale di diritto penale dell'impresa, Bologna: Monduzzi, 2000, pp. 635-663; VOGEL J., "§§ 20a, 38-40b", en: ASSMANN H.D.; SCHNEIDER U.H., Wertpapierhandelsgesetz. 
LONDOÑO, Fernando “¿Qué prohíben los artículos 52 y 53 de la Ley de Mercado de Valores? Reconstrucción dogmática de las figuras de manipulación de mercado en el derecho chileno".

Considérese en particular la siguiente definición estándar de manipulación:

“(...) manipulación de valores (...) significa una conducta dirigida a [1] inducir a personas a negociar un valor o bien a [2] forzar su precio a un nivel artificial"

En las alternativas [1] inducción a negociar y [2] forzamiento del precio se capta -no casualmente- una dicotomía taxonómica decisiva para ubicar el sentido de las prohibiciones de los arts. 52 y 53, atendiendo al mecanismo de injerencia en el precio-demercado $^{6}$. La injerencia en el precio-de-mercado puede buscarse de modo indirecto (a través de la inducción a negociar con valores, de manera que las respectivas transacciones condicionen el movimiento del precio-de-mercado en el sentido buscado por el inductor o manipulador) o bien de manera directa (forzando o determinando el movimiento del preciode-mercado mediante el ejercicio de un poder de mercado). A esta dicotomía responden geométricamente los arts. 53 (injerencia indirecta) y 52 (injerencia directa) ${ }^{7}$.

Por otra parte, un examen detenido de aquellas prohibiciones permite apreciar que el inciso $1^{\circ}$ del art. 52 y los incisos $1^{\circ}$ y $2^{\circ}$ del art. 53 de la LMV constituyen una compacta tríada de fórmulas anti-manipulativas del precio-de-mercado de títulos transados en el mercado de valores regulado por la LMV. En conjunto ${ }^{8}$, estas fórmulas dan cobertura a cada una de las modalidades que en la literatura económica y en el derecho comparado se reconocen como tipologías centrales de manipulación del mercado de valores, conforme al siguiente esquema:

[Art. 52 inc. $1^{\circ}$ ] = manipulaciones operativas propias (trade-based manipulation), bajo un presupuesto o mecanismo de injerencia directa sobre el precio-de-mercado;

[Art. 53 inc. $\left.1^{\circ}\right]=$ manipulaciones operativas impropias clásicas (fictitious-tradebased), bajo un presupuesto o mecanismo de injerencia indirecta sobre el precio-demercado (art. 53 inc. $1^{\circ}$ ); y

[Art. 53 inc. $2^{\circ}$ ] = otras formas de manipulación de injerencia indirecta sobre el preciode-mercado, incluyendo manipulaciones de hecho (action based), manipulaciones

Kommentar, Köln, 2006, pp. 727 y ss. y 1669 y ss.; TIEDEMANN, Klaus, Wirtschaftsstrafrecht: Besonderer Teil, Köln, 2006, pp. 158-162 (traducción: Manual de Derecho Penal Económico. Parte General y Especial, Valencia: Tirant Lo Blanch, 2010, pp. 380-383); ESTRADA, Albert, "Presente y futuro del delito de alteración de precios (art. 284 Cp)", InDret, 1/2014; SWAN, Edward J. \& VIRGO, John, Market Abuse Regulation, Oxford: Oxford University Press, 2d. Ed., 2010, pp. 57 y ss.; y STEINBERG, Marc I, Understanding Securities Law, $5^{\text {th }}$ ed., New Providence: Lexis Nexis, 2009, pp. 259-260, pero también pp. 243 y ss. por lo que se refiere al contexto normativo más amplio.

${ }^{5}$ THEL, Steve, "The Original Conception of Section 10(b) of The Securities Exchange Act", Stan. L. Rev., vol. 42 (1989-1990), pp. 3885 y ss, p. 393.

${ }^{6}$ Distinción ya en LONDOÑO, "Ilícito de manipulación", cit. nota nº 2, p. 103, apartado 2.6.1.b.

${ }^{7}$ Cfr. LONDOÑO, "Aproximación histórico-comparada", cit. nota $\mathrm{n}^{\circ} 1$, pp. 456 y ss., apartado 2.2. para un desarrollo del punto, con base a las taxonomías de manipulación y sus correlatos en derecho comparado de la Unión Europea y de los Estados Unidos de América.

${ }^{8}$ A la tríada puede asociarse también el art. 61 LMV; al respecto, cfr. infra 2.6. 


\section{Polít. crim. Vol. 12, No 24 (Diciembre 2017), Art. 13, pp. 1106-1183. [http://www.politicacriminal.cl/Vol_12/n_24/Vol12N24A13.pdf]}

\section{informativas (information based) y demás manipulaciones operativas impropias no cubiertas en el inciso $1^{\circ} \mathrm{del}$ art. 53.}

Enriquecida esta secuencia esquemática con la incorporación de algunos elementos descriptivos ${ }^{9}$, resulta el siguiente cuadro:

\begin{tabular}{|c|c|c|c|c|}
\hline $\begin{array}{l}\text { Título } \\
\text { VIII } \\
\text { LMV }\end{array}$ & $\begin{array}{l}\text { Fórmula sintética } \\
\text { LMV }\end{array}$ & $\begin{array}{l}\text { Cobertura típica } \\
\text { (taxonómica) }\end{array}$ & $\begin{array}{l}\text { Mecanismo } \\
\text { Manipulativo } \\
\text { (mecanismo } \\
\text { abstracto) }\end{array}$ & $\begin{array}{l}\text { Vehículo o faz externa de la } \\
\text { manipulación } \\
{\text { (mecanismo concreto })^{11}}\end{array}$ \\
\hline $\begin{array}{l}\text { Art. } \\
52 \\
\text { inc. } 1^{\circ}\end{array}$ & $\begin{array}{l}\text { Transacciones con } \\
\text { el objeto de } \\
\text { estabilizar o hacer } \\
\text { variar } \\
\text { artificialmente los } \\
\text { precios }\end{array}$ & $\begin{array}{l}\text { Manipulaciones } \\
\text { operativas propias (ej, } \\
\text { estabilización y otras } \\
\text { formas disruptivas de } \\
\text { trading) }\end{array}$ & $\begin{array}{l}\text { Injerencia } \\
\text { directa sobre } \\
\text { el precio-de- } \\
\text { mercado }\end{array}$ & $\begin{array}{l}\text { Transacciones (reales), } \\
\text { condicionantes del precio-de- } \\
\text { mercado (en virtud del ejercicio de } \\
\text { un poder de mercado, incluyendo } \\
\text { en principio la constricción o abuso } \\
\text { de posición) }\end{array}$ \\
\hline \multirow[t]{2}{*}{$\begin{array}{l}\text { Art. } \\
53 \\
\text { inc. } 1^{\circ}\end{array}$} & $\begin{array}{l}\text { Cotizaciones } \\
\text { Ficticias }\end{array}$ & \multirow{2}{*}{$\begin{array}{l}\text { Manipulaciones } \\
\text { operativas impropias } \\
\text { clásicas (ej. painting the } \\
\text { tape; fictitious-trade- } \\
\text { based del tipo wash } \\
\text { sale/purchase y match- } \\
\text { order) }\end{array}$} & \multirow{2}{*}{$\begin{array}{l}\text { Injerencia } \\
\text { indirecta } \\
\text { sobre el } \\
\text { precio-de- } \\
\text { mercado }\end{array}$} & $\begin{array}{l}\text { Cotizaciones ficticias, inductivas de } \\
\text { transacciones (reales) de terceros } \\
\text { (ajenos al engaño manipulativo) }\end{array}$ \\
\hline & $\begin{array}{l}\text { Transacciones } \\
\text { ficticias }\end{array}$ & & & $\begin{array}{l}\text { Transacciones ficticias, inductivas } \\
\text { de transacciones (reales) de terceros } \\
\text { (ajenos al engaño manipulativo) }\end{array}$ \\
\hline \multirow[t]{4}{*}{$\begin{array}{l}\text { Art. } \\
53 \\
\text { inc. } 2^{\circ}\end{array}$} & \multirow[t]{3}{*}{$\begin{array}{l}\text { Inducción engañosa } \\
\text { o fraudulenta a la } \\
\text { compra o venta de } \\
\text { valores }\end{array}$} & $\begin{array}{l}\text { Manipulaciones de } \\
\text { hecho o por vía de } \\
\text { actividades engañosas } \\
\text { extra bursátiles (action } \\
\text { based manipulation) }\end{array}$ & \multirow[t]{4}{*}{$\begin{array}{l}\text { Injerencia } \\
\text { indirecta } \\
\text { sobre el } \\
\text { precio-de- } \\
\text { mercado }\end{array}$} & $\begin{array}{l}\text { Hecho o actividad engañosa, } \\
\text { inductivas de transacciones (reales) } \\
\text { de terceros (ajenos al engaño } \\
\text { manipulativo) }\end{array}$ \\
\hline & & $\begin{array}{l}\text { Manipulaciones } \\
\text { informativas }\end{array}$ & & $\begin{array}{l}\text { Información falsa o engañosa, } \\
\text { inductiva de transacciones (reales) } \\
\text { de terceros (ajenos al engaño } \\
\text { manipulativo) }\end{array}$ \\
\hline & & $\begin{array}{lr}\text { Manipulaciones } \\
\text { realizadas mediante } & \text { un } \\
\text { complejo } & \text { de } \\
\text { transacciones } & \mathrm{e} \\
\text { informaciones } & \\
\end{array}$ & & $\begin{array}{l}\text { Transacciones e informaciones } \\
\text { engañosas, inductivas de } \\
\text { transacciones (reales) de terceros } \\
\text { (ajenos al engaño manipulativo) }\end{array}$ \\
\hline & $\begin{array}{l}\text { Transacciones } \\
\text { engañosas o } \\
\text { fraudulentas, } \\
\text { inductivas }\end{array}$ & $\begin{array}{l}\text { Otras manipulaciones } \\
\text { operativas impropias } \\
\text { (no cubiertas por el } \\
\text { inc. } 1^{\circ} \text { del art. } 53 \text { ) }\end{array}$ & & $\begin{array}{l}\text { Transacciones engañosas, } \\
\text { inductivas de transacciones (reales) } \\
\text { de terceros (ajenos al engaño } \\
\text { manipulativo) }\end{array}$ \\
\hline
\end{tabular}

\footnotetext{
${ }^{9}$ Esquema ya en LONDOÑO, “Aproximación histórico-comparada”, cit. nota ${ }^{\circ} 1$, p. 462, si bien aquí complementado y clarificado en algunos puntos.

${ }^{10}$ Cfr. LONDOÑO, "Ilícito de manipulación", cit. nota n 2, p. 103, apartado 2.6.1. b).

${ }^{11}$ Cfr. LONDOÑO, "Ilícito de manipulación", cit. nota $n^{\circ}$ 2, p. 104, apartado 2.6.1.c) y p. 115, apartado. 3.4. Aquí se ha procurado simplificar la nomenclatura usada en dicho trabajo.

${ }^{12}$ En línea con lo defendido en LONDOÑO, “Aproximación histórico-comparada”, cit. nota n 1, pp. 400-401 y 456-457, se hace aquí explícita una enmienda respecto de una sub-distinción ofrecida en LONDOÑO, "Ilícito de manipulación", cit. nota $\mathrm{n}^{\circ}$ 2, p. 105: las manipulaciones que operan mediante acaparamientoconstricción o abuso de posición han de entenderse como formas de manipulación de injerencia directa. Entenderlas como formas de injerencia indirecta resulta algo artificioso, pues en estos casos la alteración de los precios se da, de hecho, mediante una directa restricción de la oferta (que normalmente otorga el poder para imponer un precio en desmedro del short-seller). Si acaso un supuesto semejante puede configurase en los mercados chilenos y quedar cubierto por las prohibiciones del Título VIII, eso es ya otra cuestión: con más detalle, cfr. infra 2.2.1.
} 
LONDOÑO, Fernando “¿Qué prohíben los artículos 52 y 53 de la Ley de Mercado de Valores? Reconstrucción dogmática de las figuras de manipulación de mercado en el derecho chileno".

Que esta lectura resulta armónica con el derecho comparado más gravitante en el sector bursátil - europeo comunitario y federal estadounidense- es algo que se tuvo ocasión de justificar en otro lugar ${ }^{13}$. Lo que aquí se procurará demostrar es que esta lectura de los arts. 52 y 53 LMV encuentra firme apoyo en el contexto normativo interno: en la génesis y la sistemática de la LMV, en los instrumentos de autorregulación de las Bolsas, en jurisprudencia relevante del sector y en literatura disponible en el medio nacional. A esta demostración (1) se dedica el primer apartado. A partir de aquella base toma impulso la detallada reconstrucción dogmática del Título VIII LMV, a la cual se dedica el extenso segundo apartado (2), incluyendo también una propuesta para el alcance del art. 61 LMV. En fin, el artículo se cierra (3) con una propuesta hermenéutica lineal -pasaje por pasajepara las prohibiciones de los arts. 52 y $53 \mathrm{LMV}$, constitutivas del sub-tipo penal de la letra e) del art. 59 LMV.

\section{El Título VIII LMV en el contexto normativo local: elementos de derecho interno consistentes con la tesis}

En lo que sigue se ofrece un panorama de los elementos de derecho interno que avalan la tesis anticipada en la Introducción. El reconocimiento de estos elementos servirá de base para acometer con posterioridad una reconstrucción dogmática del Título VIII.

\subsection{Génesis normativa: proyecto de LMV, de 30 de diciembre de 1980}

Sin mayor preámbulo, considérese el siguiente pasaje de la historia de la LMV. Éste pone de manifiesto que la finalidad del Título VIII apuntaba a la contención del tipo de lesividad introducida por la manipulación del mercado de valores:

"El Título VIII se refiere a las actividades prohibidas. Al respecto, cabe hacer presente que la intención del legislador es expresar con toda claridad y hasta donde sea posible, para que el día de mañana el Poder Judicial lo califique, cualquiera tentativa que lleve a la distorsión del mercado, de la realidad del mercado, del resultado de la libre competencia, y así, por ejemplo, todas las transacciones que tiendan a estabilizar artificialmente los precios serán actividades prohibidas, con las sanciones que la misma ley establece." (de la Relación de Salvador Gutiérrez Asenjo, Acta N 30/81. Fecha 15 de octubre, 1981, p. 112 del Compendio BCN de la historia de la LMV. La cursiva es nuestra) $)^{14}$.

Si se atiende al contexto histórico-comparado descrito por el suscrito en otro lugar ${ }^{15}$, no debería resultar extraño que nuestra LMV incluyera una sección dedicada a las actividades

${ }^{13}$ Cfr. LONDOÑO, "Aproximación histórico-comparada", cit. nota ${ }^{\circ} 1$, passim, con referencia a los numerales 1, 2 y 6 de la sección 9(a) de la Securities Exchange Act de 1934 del derecho federal de los EE.UU. (en adelante SEA 1934) y la Regulación de Abusos de Mercado de la Unión Europea (Reglamento [UE] No 596/2014 sobre Abuso de Mercado, en adelante RAM 2014; y Directiva 2014/57/UE sobre Abuso de Mercado, en adelante DAM 2014).

${ }^{14}$ Los pasajes en cursiva son muy claros. Por otra parte nótese que no se alude a la "libre competencia", sino al "resultado de la libre competencia", lo que parece sugerir entonces la idea del precio-de-mercado como output de aquella libre competencia.

${ }^{15}$ Cfr. LONDOÑO, “Aproximación histórico-comparada”, cit. nota n 1, passim. 
Polít. crim. Vol. 12, № 24 (Diciembre 2017), Art. 13, pp. 1106-1183.

[http://www.politicacriminal.cl/Vol_12/n_24/Vol12N24A13.pdf]

prohibidas en el mercado de valores, cuyo contenido coincidiera precisamente con el hasta entonces tópico dominante en la principal regulación comparada de referencia: la prohibición de la manipulación del mercado de valores ${ }^{16}$.

En esta línea, resulta decisivo atender a la génesis de los vigentes arts. 52 y 53 LMV. Considérese para ello el tenor del artículo 48 del proyecto de ley original del Ministerio de Hacienda de la época (Mensaje, 30 de diciembre de 1980) ${ }^{17}$, texto que sirvió de base para los arts. 52 y 53 . El art. 48 en cuestión rezaba:

"Es contrario a la presente ley efectuar cotizaciones o transacciones ficticias respecto de cualquier valor, ya sea que las transacciones se lleven a cabo en el mercado de valores o a través de negociaciones privadas.

Ninguna persona podrá efectuar transacciones o inducir o intentar inducir a la compra o venta de valores, regidos o no por este [sic] ley, por medio de cualquier acto, práctica, mecanismo o artificio engañoso o fraudulento.

Las actividades de estabilización efectuadas con el objeto de llevar adelante una distribución de valores en el público, podrán realizarse sólo de acuerdo a reglas de carácter general que la Superintendencia emita al efecto"18.

Como se observó en otro lugar ${ }^{19}$, el diseño de aquel art. 48 se condice con la arquitectura de tres de las principales subsecciones de la §9(a) de la Securities Exchange Act de 1934 de los EE.UU. (en adelante SEA'34). Así, se prohíben primero las cotizaciones y transacciones ficticias, como lo hace la hipótesis (1) de la $\$ 9(a)^{20}$. Luego, en un segundo inciso, se prohíben las transacciones manipulativas y las demás formas de manipulación por vía inductiva o engañosa, a semejanza de la hipótesis (2) de la $\$ 9(a)^{21}$. En fin, se cierra el art. 48 con un anticipo de regulación de las actividades de estabilización, en lo que se advierte un reflejo de la hipótesis (6) de la $\$ 9(a)^{22}$. El diseño del art. 48 resulta lógico y diáfano bajo este prisma de análisis comparado. El sentido anti-manipulativo del Título VIII se deja explicar así con naturalidad.

Durante la tramitación del proyecto de ley que daría lugar a la LMV, el texto del art. 48 sería dividido y complementado para dar vida a los arts. 52 y 53 del texto definitivo. Para captar mejor lo que se dirá a continuación, puede resultar útil ubicar los textos comentados en un plano paralelo (las diferencias se destacan en negrita):

\footnotetext{
${ }^{16}$ La sintonía entre el Título VIII y la sección 9(a) de la SEA 1934 del derecho federal de los EE.UU. es tal, que puede postularse con plausibilidad la existencia de una influencia de dicha regulación sobre la nuestra: cfr. LONDOÑO, “Aproximación histórico-comparada", cit. nota ${ }^{\circ} 1$, pp. 408 y ss., especialmente pp. 412413. Por otra parte, ha de descartarse como posible fuente la antigua regulación de las bolsas en Chile, contenida en el D.F.L. N 251 de 1931 (de Compañías de Seguros, Sociedades Anómimas y Bolsas de Comercio), cuyo título IV "De las operaciones bursátiles" nada contiene en lo pertinente. En lo demás, esta normativa sólo contempla un tipo penal de falsedades societarias (art. 137) que puede considerarse antecesor del tipo del art. 134 de la vigente ley $\mathrm{N}^{\circ} 18.046$ de sociedades anónimas.

${ }^{17}$ Compendio de Historia de la Ley 18.045 (BCN), p. 28.

${ }^{18}$ Proyecto de ley de 30 de diciembre de 1980, en: Compendio de Historia de la Ley 18.045 (BCN), p. 28

${ }^{19}$ Cfr. LONDOÑO, "Aproximación histórico-comparada”, cit. nota n ${ }^{\circ} 1$, pp. 410 y ss.

${ }^{20}$ Cfr. LONDOÑO, "Aproximación histórico-comparada", cit. nota n ${ }^{\circ} 1$, pp. 424 y ss.

${ }^{21}$ Cfr. LONDOÑO, "Aproximación histórico-comparada", cit. nota $n^{\circ} 1$, pp. 414 y ss.

${ }^{22}$ Cfr. LONDOÑO, “Aproximación histórico-comparada”, cit. nota n 1, pp. 428 y ss.
} 
LONDOÑO, Fernando “¿Qué prohíben los artículos 52 y 53 de la Ley de Mercado de Valores? Reconstrucción dogmática de las figuras de manipulación de mercado en el derecho chileno".

\begin{abstract}
Proyecto de LMV (30 de diciembre de 1980)
Art. 48.- Es contrario a la presente ley efectuar cotizaciones o transacciones ficticias respecto de cualquier valor, ya sea que las transacciones se lleven a cabo en el mercado de valores o a través de negociaciones privadas.

Ninguna persona podrá efectuar transacciones o inducir o intentar inducir a la compra o venta de valores, regidos o no por este [SIC] ley, por medio de cualquier acto, práctica, mecanismo o artificio engañoso o fraudulento.
\end{abstract}

Las actividades de estabilización efectuadas con el objeto de llevar adelante una distribución de valores en el público, podrán realizarse sólo de acuerdo a reglas de carácter general que la Superintendencia emita al efecto.

\section{LMV, Texto vigente}

Art. 53.- Es contrario a la presente ley efectuar cotizaciones o transacciones ficticias respecto de cualquier valor, ya sea que las transacciones se lleven a cabo en el mercado de valores o a través de negociaciones privadas.

Ninguna persona podrá efectuar transacciones o inducir o intentar inducir a la compra o venta de valores, regidos o no por esta ley, por medio de cualquier acto, práctica, mecanismo o artificio engañoso o fraudulento.

Art. 52.- Es contrario a la presente ley efectuar transacciones en valores con el objeto de estabilizar, fijar o hacer variar artificialmente los precios.

Sin perjuicio de lo dispuesto en el inciso anterior, podrán efectuarse actividades de estabilización de precios en valores de acuerdo a reglas de carácter general que imparta la Superintendencia y únicamente para llevar adelante una oferta pública de valores nuevos o de valores anteriormente emitidos y que no habían sido objeto de oferta pública.

Nótese que los incisos $1^{\circ}$ y $2^{\circ}$ del art. 48 coinciden exactamente con el vigente art. 53. Por su parte, el inciso $3^{\circ}$ del art. 48 servirá de base para la elaboración del definitivo art. 52, mediante la inclusión de una fórmula inequívocamente anti-manipulativa, dirigida a la prohibición de las manipulaciones operativas (de aquellas propias).

En la historia de la LMV (en su versión original de 1981) no hay explicación o constancia alguna sobre la razón de estos cambios; es decir, sobre el porqué de la creación de un art. 52 a partir de la costilla del inciso $3^{\circ}$ del art. 48. A juicio del suscrito, el sentido de las modificaciones es doble.

Por una parte, ella vino a aclarar desde el inicio el contenido anti-manipulativo del Título, encabezándolo con una inequívoca prohibición general en materia de manipulaciones operativas. Así aparece el inciso $1^{\circ}$ del vigente art. 52, no contenido en el proyecto original:

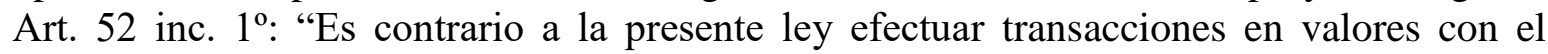
objeto de estabilizar, fijar o hacer variar artificialmente los precios".

Se explica de este modo una de las razones por la que aquí defiende una lectura del art. 53 en concordancia sistemática con el art. 52. En efecto, que corresponda leer el artículo 53 bajo la luz arrojada por el propio art. 52 -la luz de una cláusula inequívocamente antimanipulativa- es algo que se aviene muy bien a la historia de las disposiciones. 
Polít. crim. Vol. 12, № 24 (Diciembre 2017), Art. 13, pp. 1106-1183.

[http://www.politicacriminal.cl/Vol_12/n_24/Vol12N24A13.pdf]

Que una lectura semejante es correcta lo demuestra una simple constatación. El texto del art. 48 del proyecto de LMV no contenía una fórmula como la del actual inciso $1^{\circ}$ del art. 52. Eso es claro; y sin embargo el art. 48 igualmente planteaba un régimen excepcional (a modo de justificante) para las actividades de estabilización (en su inciso $3^{\circ}$; véase supra columna izquierda del cuadro). Dado que las estabilizaciones constituyen inequívocamente manipulaciones operativas, ¿cómo podía el texto del proyecto sentar ese régimen excepcional -justificado- sin antes prohibir las manipulaciones operativas? Pues bien, sucede que sí disponía tal prohibición, justamente mediante la cláusula amplia del inciso $2^{\circ}$ del art. 48, que prohibía "efectuar transacciones o inducir o intentar inducir a la compra o venta de valores, regidos o no por este [sic] ley, por medio de cualquier acto, práctica, mecanismo o artificio engañoso o fraudulento".

En otras palabras, en el proyecto de LMV la prohibición de a lo menos una categoría de manipulaciones operativas se desprendía precisamente del inciso que más tarde pasaría a ser inciso $2^{\circ}$ del vigente art. 53 (por más que con razonables dudas de cobertura en materia de manipulaciones operativas propias, según se ilustrará de inmediato). Esta lectura da sentido sistemático al inciso $3^{\circ}$ del art. 48, relativo a las actividades de estabilización. No es razonable sostener que un mismo texto pueda mutar radicalmente de sentido a raíz de una modificación meramente aclaratoria en un texto conexo. El vigente inciso $2^{\circ}$ del art. 53 conserva en efecto el sentido anti-manipulativo que tenía en el marco del art. 48 del proyecto $\mathrm{LMV}^{23}$.

Así las cosas, la introducción del inciso $1^{\circ}$ del vigente art. 52 vino a representar una mejora en términos de clarificación del sentido general del Título. Considérese además que este inciso se acerca más al tenor de la hipótesis (6) de la §9(a) SEA’34, lo que no viene sino a ratificar la plausibilidad de una influencia en la especie.

Si el anotado cambio representa una mejora clarificadora del sentido general del Título VIII, con él se introdujo a la vez una dificultad interpretativa relativa al inciso $2^{\circ}$ del art. 53. Como se ha dicho, en el art. 48 del proyecto de ley original la modalidad comisiva consistente en "efectuar transacciones" (primera variante del art. 53 inc. $2^{\circ}$ ) servía desde ya como fórmula comprensiva de las manipulaciones operativas (trade based manipulation); lo anterior, amén de la amplia cobertura ofrecida por la fórmula de "inducción a la compra o venta de valores" (segunda variante del art. 53 inc. $2^{\circ}$ ). Nótese entonces que sólo a partir de la configuración del art. 52 -sobre la base del inciso $3^{\circ}$ del original art. 48 - se produce una eventual redundancia en el plano de la cobertura de las manipulaciones operativas, abriendo así la pregunta acerca de si este "efectuar transacciones mediante mecanismos engañosos o fraudulentos" o bien "la inducción a la compra o venta" podían tener un sentido no anti-manipulativo o en todo caso distinto al del inciso $1^{\circ}$ del art. 52 (como por ejemplo un fraude cometido mediante engaño, entre otras hipótesis imaginable). Esa pregunta carecería de sentido de cara al texto del proyecto de LMV de 1980.

\footnotetext{
${ }^{23}$ Por lo demás, hace sentido afirmar aquello en la medida que el inciso $2^{\circ}$ en cuestión (del art. 48 del proyecto y del art. 53 vigente) se asemeja a la fórmula anti-manipulativa más amplia de la §9(a) de la SEA 1934 (la hipótesis [2]), según se ha procurado demostrar en LONDOÑO, "Aproximación históricocomparada", cit. nota $\mathrm{n}^{\circ} 1$, pp. 414 y ss.
} 
LONDOÑO, Fernando “¿Qué prohíben los artículos 52 y 53 de la Ley de Mercado de Valores? Reconstrucción dogmática de las figuras de manipulación de mercado en el derecho chileno".

Sin perjuicio de lo que se dirá más adelante (infra 2), la duda interpretativa ha de responderse en los siguientes términos: el inciso $2^{\circ}$ del art. 53 tiene el mismo sentido antimanipulativo del art. 52, pero su énfasis está puesto en la cobertura de una tipología diversa de manipulación, atendiendo al mecanismo de acción ${ }^{24}$. Así, mientras el tenor de la primera variante del inciso $2^{\circ}$ del art. 53 apunta específicamente a aquel tipo de manipulaciones operativas que actúa en los precios mediante el recurso al engaño (mecanismo indirecto de manipulación de los precios), el tenor del inciso $1^{\circ}$ del art. 52 es más amplio, por de pronto comprensivo de las manipulaciones operativas que actúan en los precios directamente, en virtud de transacciones disruptivas o mediante un ejercicio abusivo de un poder de mercado (mecanismo directo de manipulación de los precios). A esta variante se refiere el concepto de manipulación operativa propia, mientras que aquella que actúa sobre la base del engaño que introducen determinadas transacciones es comprendida por el concepto de manipulación operativa impropia.

Avanzando en el razonamiento anterior, se está ya en condiciones de explicitar el segundo sentido de las modificaciones que sufrió el Título VIII durante el trámite de elaboración de la LMV. La creación del art. 52 durante la tramitación de la LMV original no vino a alterar el sentido anti-manipulativo del art. 53 (ex art. 48), sino a aclarar o explicitar que las manipulaciones operativas propias -aquellas que actúan mediante poder de mercado y sin valerse de engaño alguno- también están prohibidas. Esa cobertura no era para nada clara al tenor del art. 48 del proyecto original, que -como se ha dicho- parecía aludir exclusivamente a aquellas manipulaciones que actúan mediante engaño o inducción; es decir, el art. 48 del proyecto sólo daba una cobertura inequívoca a las manipulaciones operativas impropias, a las manipulaciones informativas (information based) y a las manipulaciones de hecho o realizadas mediante actividades engañosas extra bursátiles (action based).

En suma, el inciso $1^{\circ}$ del art. 52 vino a reforzar la cobertura de las manipulaciones, asegurando o clarificando la prohibición de las manipulaciones operativas propias ${ }^{25}$. Pero con ello no ha de entenderse mutado el sentido del vigente art. 53, que en su texto original (art. 48) buscaba igualmente dar cobertura a manipulaciones operativas (por de pronto aquellas que consistían en actividades de estabilización).

\subsection{Pre comprensión del Título VIII en nuestro medio: jurisprudencia administrativa y penal, instancias de autorregulación y doctrina nacional}

En lo que sigue se ofrecerán antecedentes relativos a la precomprensión existente en nuestro medio en torno al Título VIII LMV, y a su art. 53 en especial. Se alude aquí a una precomprensión, pues se trata de figuras todavía incipientemente tratadas, de modo que no

\footnotetext{
${ }^{24}$ Véase al respecto lo dicho en LONDOÑO, “Aproximación histórico-comparada", cit. nota $n^{\circ} 1$, pp. 456457.

${ }^{25}$ Por lo demás, una tipología de manipulación no siempre fácil de distinguir de las transacciones lícitas y, por tanto, de más difícil persecución en la práctica. Al respecto, Cfr. LONDOÑO, "Ilícito de manipulación", cit. nota $\mathrm{n}^{\circ} 2$, pp. 106-107.
} 
pueden afirmarse tomas de posición consolidadas o estables. Con todo, el (todavía escaso) material disponible en nuestro medio tiende a avalar la tesis aquí defendida.

En primer término se dará cuenta de material jurisprudencial, para luego abordar la normativa y los instrumentos generados por los regulados, especialmente los Reglamentos de la Bolsa de Comercio y de la Bolsa Electrónica, así como la guía de prevención de abusos de mercado elaborada por el Comité de autorregulación de ambas Bolsas. En tercer término, se dará cuenta de la (poca) doctrina nacional que se ha pronunciado sobre el tema.

\subsubsection{Jurisprudencia administrativa y penal}

Hasta donde alcanzo a ver, al menos dos son los casos inequívocamente reconducibles a las tipologías de manipulación, investigados y sancionados en los últimos treinta y cinco años en nuestro medio, ya por aplicación del Título VIII, ya por aplicación del art. $61 \mathrm{LMV}^{26}$. El primero, conocido como caso $M B I$, fue sólo objeto de sanciones de índole administrativa por la Superintendencia de Valores y Seguros (en adelante SVS). El segundo, conocido como caso Schwager, fue objeto tanto de sanciones administrativas como penales.

Hasta hace poco, el caso Schwager constituía el único con condena penal por sentencia ejecutoriada por el delito del art. 59 e) LMV en relación con el inciso $2^{\circ}$ del art. 53. Esa exclusividad se rompió el 11 de agosto de 2015 con la arista Corredoras del caso Inverlink $^{27}$, un caso en el que se condenó también por el art. 59 e) LMV en relación con el

\footnotetext{
${ }^{26}$ Un tercer caso lo constituye la arista Corredoras del caso Inverlink, pero su tratamiento como un caso de auténtica manipulación es a lo menos problemático, según se detalla en la nota al pie siguiente. También de interés podrían resultar aquellos casos en los cuales se persigue la responsabilidad de emisores que entregan información falsa en estados financieros u otras comunicaciones obligadas, en la medida que a aquellos la SVS atribuye - correctamente a mi modo de ver - una calificación bajo el art. 59 a) o f), sin que se pretenda del inciso $2^{\circ}$ del art. 53 un alcance como el que ya aquí se ha criticado, emulando la vigencia práctica de la Regla 10b-5 en el ordenamiento federal de los EE.UU. El caso conocido como "La Polar" se ubica en ese contexto (cfr. para los hechos, SVS, Res. Exenta No 083, de 9 de marzo de 2012, así como - para la sede penal - la sentencia de procedimiento abreviado del 2do. Juzgado de Garantía de Santiago, de 18 y 24 de diciembre de 2015, RIT 6930-2011).

${ }^{27}$ Cfr. Excma. Corte Suprema en causa Rol No 176-739-M, Rol de Corte N ${ }^{\circ}$ 1964-15 (Inverlink-arista Corredoras). Los hechos de esta arista del caso Inverlink son bien conocidos, aunque puede ser de interés resumirlos aquí: desde mediados de los '90 y hasta el año 2002 un funcionario de la mesa de dinero de CORFO se habría coludido con agentes de Inverlink Corredoras de Bolsa S.A. para negociar instrumentos financieros de renta fija (depósitos a plazo) por cuenta de la entidad pública, bajo una modalidad de falsa recompra (de modo que CORFO pagaba por los instrumentos pero estos permanecían en poder de Inverlink, sin contrapartida económica que lo justificara). La falsa recompra consistía simplemente en la adulteración de los respectivos registros de CORFO por parte del propio funcionario coludido. Todo lo anterior, por cierto, en perjuicio del ente público y con la correspondiente ventaja financiera para los particulares. Los perjuicios irrogados a CORFO bordearon los 30.000 millones de pesos. Se habría tratado entonces de una defraudación patrimonial en perjuicio de CORFO, en principio plausiblemente subsumible bajo el tipo penal tradicional de fraude al fisco, del art. 239 del Código Penal. ¿Por qué entonces se acudió a la regulación de mercado de valores, en particular a la figura del inc. $2^{\circ}$ del art. 53 LMV? Una circunstancia fáctica incidental lo explica. Y es que las operaciones descritas se realizaron utilizando a dos corredoras bancarias como intermediarias (Scotia Corredora de Bolsa y BBVA Corredora de Bolsa) en el canal Inverlink-CORFO. ¿Por qué esta intermediación? En principio sólo para eludir las restricciones de la Resolución No 901 de 18 de enero de 1996 del Comité Ejecutivo de CORFO, en virtud de la cual el ente público acordó "limitar las operaciones de su mesa de dinero estableciendo que ésta sólo podía adquirir instrumentos financieros de entidades bancarias,
} 


\section{LONDOÑO, Fernando “¿Qué prohíben los artículos 52 y 53 de la Ley de Mercado de Valores? Reconstrucción dogmática de las figuras de manipulación de mercado en el derecho chileno".}

art. 53 de la misma ley, si bien bajo una lectura inadecuada de sus términos; mejor dicho, sin que se ofreciera siquiera una reconstrucción del alcance de la prohibición del inc. $2^{\circ}$ del art. $53 \mathrm{LMV}$, mucho menos una caracterización de sus distintos elementos. La sentencia agota su esfuerzo interpretativo en la captación de algunos pocos principios o presupuestos normativos subyacentes al sistema regulado de oferta pública de valores de nuestra LMV. Lo hace de modo totalmente genérico, sin referencia a los presupuestos específicos del Título VIII LMV o su artículo $53^{28}$.

sociedades financieras y filiales de bancos, sujetos a la supervigilancia de la Superintendencia de Banco e Instituciones Financieras y además, que sólo podía operar con Corredoras de Bolsa, Agencias de Valores y Administradoras de Fondos Mutuos que fueran filiales o propiedades de bancos" (considerando $19^{\circ}$ ). Los personeros coludidos - que hasta entonces podían "negociar" directamente - se vieron así forzados a buscar en corredoras bancarias un conducto para sus operaciones, dejando en lo demás intacta la maniobra defraudatoria del ente público (falsas recompras, con los respectivos egresos indebidos de dineros desde CORFO hacia Inverlink). Pues bien, no es en el diseño global, ni en el output de la operación, que la Corte Suprema ve una infracción al inciso $2^{\circ}$ del art. 53 LMV (todo lo cual, como se ha dicho, se aviene en principio con un delito de fraude al fisco), sino que es en estas operaciones intermedias o triangulaciones vía corredoras bancarias que el máximo tribunal reconoce un injusto de alcance bursátil. El fundamento de la subsunción es el ocultamiento de información que estas triangulaciones supusieron. Ellas habrían impedido que CORFO advirtiese la vulneración a la limitación operativa impuesta por su Resolución № 901 de 1996 (aunque ello no necesariamente habría significado desvelar el trasfondo de las operaciones: la colosal defraudación patrimonial en su perjuicio). Pueden advertirse razones "estratégicas" (procesales y de índole indemnizatorio) para dirigir una acción contra las corredoras o sus agentes (como "principales" de un delito), pero ello ciertamente no excusa de la necesidad de subsumir adecuadamente los hechos bajo el tipo penal invocado. Esto es lo que no se hizo, según se expondrá con más detalle en la nota al pie siguiente.

${ }^{28}$ La nota anterior se ocupa de los hechos. Algunas observaciones sobre la subsunción ofrecida por la Corte Suprema son obligadas aquí. Lo primero que puede observarse es que la Corte Suprema no haya procurado definir los alcances de la conducta prohibida en el art. 53, ni aún en términos aproximados. Esta sola circunstancia merecería una crítica importante, por cierto, tratándose de una prohibición especialmente necesitada de alguna clarificación. En lugar de ofrecer el sentido o alcance de la disposición, la Corte recurre a un principio (el principio de información) para fundar su condena. Conecta entonces aquel principio con los deberes de las corredoras para con sus clientes, de modo que luego puede afirmar que una transgresión a aquel principio se observó allí donde no se informó a CORFO que se estaba intermediando por cuenta de Inverlink Corredoras. Así las cosas, la exigencia de "transparencia de los mercados" parece reducida por la sentencia a una exigencia de transparencia individual o privada, cual (mera) infracción a determinados deberes contractuales de información. Es evidente sin embargo que no se agota en este tipo de "transparencia privada" el fundamento de la regla de mandatory disclosure o revelación obligatoria de información que se encuentra en la base de todo mercado regulado de valores, como es el caso de los artículos $9^{\circ}$ y $10^{\circ}$ de la LMV chilena. ¿Habrá de verse entonces un crimen del art. 53-59e] allí donde, por ejemplo, un corredor no le informe a un cliente sobre la composición societaria, identidad de control o perfil de riesgo de una determinada sociedad o fondo recomendado para su inversión? ¿Otro tanto allí donde el corredor, por ejemplo, incumpla determinadas instrucciones del cliente en orden a comprar valores de tal o cual sociedad? Estos casos pueden importar graves faltas a deberes contractuales - qué duda cabe - pero para advertir un injusto de fraude patrimonial (individual) hay todavía un importante trecho. Mucho más para advertir la existencia de un injusto de connotación bursátil, de alcance supraindividual. Por otra parte, y como se procurará demostrar en este trabajo, no es atendible una lectura que pretenda ver una infracción al art. 53 LMV a partir de la mera elusión o infracción de una normativa técnico-procedimental de tipo bursátil u otra similar (como podría inferirse del razonamiento de la Corte Suprema). Dicha elusión o infracción podrá ser bastante para configurar un elemento de la prohibición (un artificio, en los términos del inciso $2^{\circ}$ del art. 53), pero con ello no puede darse por satisfecha la prohibición en su integridad. Estando al tenor literal del inciso $2^{\circ}$ del art. 53, el artificio (engañoso o fraudulento) constituye sólo un mecanismo o recurso medial de la fórmula, pero no su fin. Lo que la fórmula íntegramente considerada exige es que mediante ese artificio desde ahí - se induzca a otros a comprar o vender acciones (con la asociada finalidad de alterar el precio-de- 
Polít. crim. Vol. 12, № 24 (Diciembre 2017), Art. 13, pp. 1106-1183.

[http://www.politicacriminal.cl/Vol_12/n_24/Vol12N24A13.pdf]

No es éste el espacio para un comentario in extenso sobre estos casos y sus resoluciones. Aquí simplemente se ofrecerá una síntesis que permita dar cuenta de la lectura que en la praxis se ha hecho de algunas de las disposiciones que interesan al presente trabajo. La atención se pondrá en los casos MBI y Schwager (ambos correctamente subsumidos bajo tipologías anti-manipulativas) ${ }^{29}$.

\section{a) Caso $\mathrm{MBI}$}

Este caso involucró a MBI Corredoras de Bolsa S.A., entidad que en el curso del año 2004 realizó una serie de operaciones de compraventa con acciones de Volcán y de Pizarreño, ambas altamente ilíquidas y por tanto muy sensibles a cambios en el comportamiento del mercado. En términos generales las operaciones correspondían al patrón de transacciones ficticias de tipo lavadas o auto-compraventas (wash sales o wash transactions), de modo que MBI se compraba y vendía a sí misma las aludidas acciones desde las dos Bolsas de valores con sede en Santiago (Bolsa de Comercio y Bolsa Electrónica), a través de cuentas de dos corredoras distintas. Las operaciones se realizaron a precios, volúmenes y condiciones determinadas, de manera de lograr una progresiva alza en el precio de los instrumentos Volcán y Pizarreño, mismos que componían, junto a otros títulos, el portafolio de la cartera propia de Corredora MBI. Dicha alza en los precios se logró efectivamente, con la consecuente ganancia para MBI.

En virtud de la Resolución Exenta No 402 de 8 de septiembre de 2006, la SVS sancionó a MBI Corredores de Bolsa S.A. con una multa ascendente a U.F. 10.000 y suspensión de 10 días hábiles bursátiles por la infracción de los artículos 52 y 53 inc. $1^{\circ} \mathrm{LMV}^{30}$.

De especial interés en esta sede resultan algunos considerandos de la mencionada Resolución, de los que puede desprenderse la lectura de la SVS sobre algunas de las disposiciones que aquí nos ocupan.

En primer lugar, considérese que originalmente la SVS formuló cargos también por infracción al inciso $2^{\circ}$ del art. 53,

"toda vez que al efectuar operaciones de compra y venta en ambas bolsas, el mercado recibió una señal falsa, desde que las operaciones no correspondieron a agentes de mercado autónomos, si no que respondían a las órdenes de una misma parte, destinatario y originador de tales operaciones, haciendo aparecer transacciones sin fundamentos en la interacción de las fuerzas de oferta y demanda, pudiendo de esta

\footnotetext{
mercado). La verificación de una transacción artificiosa en los términos antes expuestos (elusiva o infractora de una norma procedimental cualquiera) no puede contar como medio y como fin a la vez, sin que con ello se vulnere el tenor de la disposición.

${ }^{29}$ Sobre el caso Inverlink-Corredoras puede bastar para los fines de este artículo con lo expuesto en las dos notas precedentes.

${ }^{30}$ Además del art. 122 del Reglamento de Operaciones de la Bolsa Electrónica. En virtud de una resolución posterior (Res. Exenta 501 de 23 de octubre de 2006) y habiendo mediado un reconocimiento de la ilegitimidad de la operaciones por parte de MBI, la SVS modificó parcialmente la sanción anterior, en el sentido de que la suspensión se limitaba a la realización de operaciones en cartera propia de MBI, por un término de 20 días hábiles, amén de la multa en UF, la que se mantuvo.
} 
LONDOÑO, Fernando “¿Qué prohíben los artículos 52 y 53 de la Ley de Mercado de Valores? Reconstrucción dogmática de las figuras de manipulación de mercado en el derecho chileno".

manera inducir al mercado a tomar decisiones considerando variables inexistentes que distorsionaban las decisiones de inversión" (SVS, Res. Ex. 402, cit., considerando 2b.-)

En este pasaje la SVS arriesga una lectura del inciso. Es interesante que allí se asocie el artículo 53 a la transmisión de señales falsas al mercado, así como al peligro de inducción al mercado a la toma de decisiones de inversión equivocadas o distorsionadas. Esa lectura del inciso $2^{\circ}$ del art. 53 es correcta, a juicio de suscrito. La lectura de la SVS reconoce en el citado inciso una fórmula anti-manipulativa en los términos que aquí se ha explicado, es decir, como una que se ejecuta mediante la introducción de alguna forma de engaño dirigido a condicionar el comportamiento de los intervinientes en el mercado (manipulación indirecta, por vía de engaño o inducción).

Por razones de mera índole probatoria, la SVS finalmente consideró no suficientemente acreditada la infracción del inciso $2^{\circ}$ del art. 53 (considerando 16 de la Res. Exenta 402), pero resulta de interés constatar que las demás disposiciones del Título VIII que sí fueron aplicadas recibieron también una lectura en clave anti-manipulativa, al menos estando a la valoración del complejo de hechos en ellas subsumidos.

Así, en la misma resolución ya citada puede leerse que,

"se desprende que MBI vulneró lo dispuesto por el artículo 52 [LMV] (...) toda vez que se ha acreditado que dicha sociedad llevó a efecto una estrategia de acumulación de las acciones Volcán y Pizarreño mediante un proceso de compra sistemático, para posteriormente, a través de una serie de operaciones de compra y venta de esas acciones por montos irrelevantes, y operando en dos bolsas de valores y con dos intermediarios diferentes, provocar un alza en el precio de cierre de dichos instrumentos, de modo tal que una vez alcanzado un determinado precio objetivo, vender toda su posición en acciones Volcán y una parte sustancial de aquellas mantenidas en acciones Pizarreño. Con ello, obtuvo una utilidad fruto de un incremento en el precio de tales valores principalmente atribuible a las operaciones en las que participó como comprador y vendedor final". (Res. Ex. 402 cit., 15) ${ }^{31}$.

\section{b) Caso Schwager}

El caso Schwager recibió mayor atención pública en su tiempo, de modo que los hechos son en general conocidos ${ }^{32}$. Dos aristas lo componen.

\footnotetext{
${ }^{31}$ Por su parte, en relación con la infracción al inciso $1^{\circ}$ del art. 53 - lugar precisamente adecuado para la subsunción de transacciones ficticias como las compraventas lavadas (wash sales) - en la misma resolución citada puede leerse que: "consta además que MBI transgredió lo dispuesto en el artículo 53 inciso $1^{\circ}$ [LMV] (...) por cuanto dichas operaciones son ficticias, dado que no responden a la libre interacción de los agentes de mercado. Lo anterior se confirma debido a que (...) su accionar no respondió a una real intención de compra o venta de las acciones cuestionadas, lo que se demuestra porque MBI compraba y vendía cantidades similares de acciones, al mismo precio, de poca cuantía, sin existir pérdidas o utilidades por dichas operaciones, siendo ello inconcuso en cuanto a la falta de sentido económico de estas transacciones." (Res. Ex. 402 cit., 15).

${ }^{32}$ Cfr. el comentario del caso en ROSENBLUT, Verónica, "El denominado caso "Schwager": análisis de histórica condena por uso de información privilegiada y manipulación bursátil", Revista Jurídica del Ministerio Público, N. 46 (marzo 2011), pp. 185-209.
} 
En la arista principal -que fue objeto de juzgamiento en sede administrativa y penal- se atribuyó al gerente general de Schwager S.A. (J. Kravetz) la divulgación de información falsa o tendenciosa sobre las posibilidades de negocio de Schwager S.A., así como sobre la existencia de transacciones que aumentarían su participación en la empresa, todo ello ejecutado hacia mediados de 2005. La información divulgada -falsamente optimista, de acuerdo a lo acreditado ${ }^{33}$ - era idónea para inducir a la compra de los títulos de Schwager, mismos que por entonces cotizaban muy bajo. El mercado efectivamente captó la información y el precio de la acción de Schwager S.A. se elevó significativamente en un período muy corto (el precio se elevó en un $146 \%$ en un período de apenas dos meses, pasando de $\$ 8.2$ a \$20,6). Por su parte, aprovechando este mayor precio, el gerente en cuestión procedió a vender -para sí y para Schwager S.A- una parte importante de los títulos bajo su control, obteniendo las respectivas ganancias. ${ }^{34}$ Esta arista fue objeto tanto de sanciones administrativas como penales, según se detallará de inmediato.

En una arista paralela, se juzgó la responsabilidad del Presidente del Diario Estrategia (V.M. Ojeda) por su contribución en la difusión de la información falsamente optimista relativa a Schwager, a través de notas y reseñas en el periódico en cuestión. Esta arista sólo fue objeto de sanción en sede administrativa.

Como puede advertirse, el caso -en sus dos aristas- responde en general al patrón de la manipulación informativa. ${ }^{35}$ Coherentemente, tanto la SVS como el Ministerio Público (por lo que se refiere a la arista principal) condujeron sus investigaciones bajo esa óptica. De todos modos, por más que siempre bajo la perspectiva de que lo que se estaba persiguiendo correspondía a una manipulación informativa, pueden advertirse diferencias de apreciación en el reconocimiento de las disposiciones infringidas. Diferencias algo paradójicas, hay que decir: en efecto, mientras el Ministerio Público demostró tener una sensibilidad fina hacia las normas de prohibición primarias -el Título VIII y su art. 53 inc. $2^{\circ}$-, la SVS dirigió su atención a una figura de directo alcance penal, como lo es el art. $61 \mathrm{LMV}^{36}$. Con todo, lo interesante para nuestros propósitos es que en ambas sedes los hechos se valoraron bajo el

\footnotetext{
${ }^{33} \mathrm{La}$ falsedad habría radicado en la titularidad y eficacia de un aditivo que reduciría la emanación de gases contaminantes en el proceso de combustión (un producto conocido como Chiss), a la vez que en la comunicación como hecho esencial de un protocolo de acuerdo con ENAP para comercializar dicho producto (omitiendo incluir una condición suspensiva que sujetaba el acuerdo a la efectiva demostración del rendimiento del producto en cuestión). Otro tanto sucede con la información relativa al presunto incremento de participación por parte de J. Kravetz (no avalado por transacciones eficaces).

${ }^{34}$ Justamente en razón de esta línea de comportamiento accionario y transaccional, el tribunal oral en lo penal consideró que los hechos - incluyendo tanto el injusto de manipulación como el de uso de información privilegiada - se dejaban subsumir bajo la categoría criminológica manipulativa conocida como "pump \& dump" (cfr. RIT 67-2010 de 19 de octubre de 2010, Considerando Decimotercero; véase también en ROSENBLUT, "El caso Schwager", cit. nota n' 32, p. 209).

${ }^{35}$ Sin perjuicio del eventual uso de información privilegiada que podría apreciarse en las operaciones de cierre de los hechos (y sin perjuicio del eventual problema de bis in idem que una imputación simultánea por manipulación y uso de información privilegiada puede plantear). En lo demás, el $4^{\circ}$ TOP de Santiago parece apreciar también la concurrencia de transacciones manipulativas, como puede leerse en el considerando Decimotercero del fallo.

${ }^{36}$ En mi opinión podría ser interesante que para fines infraccionales la SVS explorara la posibilidad de recurrir, en su caso, al art. 65 LMV en materia de publicidad, propaganda y difusión.
} 
LONDOÑO, Fernando “¿Qué prohíben los artículos 52 y 53 de la Ley de Mercado de Valores? Reconstrucción dogmática de las figuras de manipulación de mercado en el derecho chileno".

prisma anti-manipulativo, por más que en definitiva se aplicaran disposiciones distintas de la LMV.

La solución más acorde con lo aquí defendido corresponde a la adoptada en sede penal. Allí, por sentencia del $4^{\circ}$ Tribunal Oral en lo Penal de Stgo., RIT 67-2010 de 19 de octubre de $2010,{ }^{37}$ se condenó a Jacobo Kravetz por el delito de manipulación bursátil previsto en el art. 59 e) en relación con el inciso $2^{\circ}$ del art. 53 (cfr. parte Resolutiva, en cuanto a la acción penal, p. II). Avalando la teoría del caso del Ministerio Público, el tribunal expresamente reconoció el citado nomen iuris (manipulación bursátil), identificando su configuración a partir de la infracción del inciso $2^{\circ}$ del art. 53 LMV, en relación con la figura penal del art. 59 e). Sobre el particular, puede leerse en la sentencia:

"Resumiendo, pues, se provocó con engaño la compra de acciones en los usuarios a raíz de informaciones falsas, engañosas y tendenciosas, que llevaron a elevar el precio artificialmente, con lo cual queda comprobado que se cometió el delito descrito precedentemente [de manipulación bursátil]" (sentencia RIT 67-2010, 4 TOP Stgo., considerando $\left.13^{\circ}\right)$.

Cabe hacer presente que la defensa incluyó entre sus alegaciones subsidiarias la calificación de los hechos bajo el tipo penal del artículo 61 LMV, figura cuyo objeto se corresponde en principio con la manipulación informativa ${ }^{38}$, aunque con la previsión de una pena de simple delito, inferior por tanto a aquella de la figura del art. 59 e) LMV. El tribunal desechó dicha alegación, confirmando la subsunción bajo la figura de crimen del art. 59 e), por infracción al inciso segundo del artículo 53 LMV. En este contexto, el Tribunal sostuvo que "la naturaleza de los hechos se ajustan más al tipo penal asentado, por ser más preciso y encuadrarse de mejor manera -sin forzamientos jurídicos-en los presupuestos fácticos que se confirmaron" (sentencia RIT 67-2010, $4^{\circ}$ TOP Stgo., considerando $\left.13^{\circ}\right)^{39}$.

Por su parte, la SVS -en un procedimiento administrativo anterior al penal- vio en los hechos una infracción al art. 61 LMV, como figura dirigida a la sanción de la manipulación informativa. En el caso de la arista Ojeda-Diario Estrategia, efectivamente llegó a imponerse la sanción administrativa por infracción a dicha figura (SVS, Res. Exenta Num. 665 de 5 de diciembre de 2005). En el caso de la arista principal, la SVS formuló cargos por infracción al art. 61, pero en definitiva se desecharon por insuficiencia probatoria (considerando 11 de la Resolución Exenta 247 de 9 de junio de 2006, aparentemente sobre la base de un estándar de convicción más allá de toda duda razonable). En definitiva, la arista principal -incluyendo tanto a la propia Schwager S.A. como a su gerente generalsólo sería objeto de sanciones administrativas por infracción al artículo 165 LMV, en materia de uso de información privilegiada (SVS, Resolución Exenta Num. 247 de 9 de junio de 2006 y SVS, Res. Exenta Num. 253 de 9 de junio de 2006).

\footnotetext{
${ }^{37}$ Pronunciado por los Magistrados Juan Carlos Urrutia Padilla (Pdte.), Geni Morales Espinoza y Pedro Suárez Nieto.

${ }^{38}$ Sobre esto se volverá infra 2.6.

${ }^{39}$ Si bien se comparte la conclusión del Tribunal, no necesariamente se comparte su razonamiento en lo pertinente.
} 


\section{Polít. crim. Vol. 12, No 24 (Diciembre 2017), Art. 13, pp. 1106-1183. [http://www.politicacriminal.cl/Vol_12/n_24/Vol12N24A13.pdf]}

Debe decirse en todo caso que esta actitud más "conservadora" de la SVS -tendiente a ver en los hechos una mera infracción al art. $61 \mathrm{LMV}$ - se revela poco decisiva en la práctica, en la medida que en sede administrativa la diferencia sancionatoria entre una y otra calificación jurídica es escasamente relevante. Pero ese no es el caso en sede penal. En esa instancia la calificación bajo el art. 59-e) determina la concurrencia de una pena de crimen, que alcanza los diez años de presidio. Como se ha anticipado, distinta es la situación penológica bajo el art. $61 \mathrm{LMV}$, figura que al tiempo del caso sólo preveía una sanción de simple delito, correspondiente a 61 días a un máximo de 3 años de presidio ${ }^{40}{ }^{41}$. Sobre el alcance del art. 61 y su relación con el art. 53 se volverá (infra 2.6).

1.2.2. Instrumentos de autorregulación del sector

De la pre-comprensión de los regulados pueden también extraerse claros argumentos en apoyo de la tesis aquí defendida. En particular se aludirá a la normativa contenida en el Reglamento de la Bolsa de Comercio de Santiago, el Reglamento de Operaciones de la Bolsa Electrónica de Chile, el Manual de Operaciones en Acciones de la Bolsa de Comercio de Santiago y en las Reglas del Comité de Autorregulación de las Bolsas para prevenir y combatir el uso de información privilegiada y la manipulación del mercado, de abril de $2009^{42}$.

a) Reglamentos de las Bolsas de Valores (Reglamento de la Bolsa de Comercio de Santiago y Reglamento de Operaciones de la Bolsa Electrónica de Chile)

En buena medida los Reglamentos de las Bolsas de Valores se limitan a reproducir literalmente o parafrasear las prohibiciones del Título VIII de la LMV. Hay sin embargo al menos una disposición de interés, en cuanto innova en la formulación de una de las prohibiciones, dando luces sobre su sentido anti-manipulativo.

A continuación se reproducen las disposiciones pertinentes de los Reglamentos de las Bolsas de Valores. Las disposiciones de uno y otro Reglamento son idénticas, con el solo cambio de numeración del articulado. Entre corchetes se indica la referencia

\footnotetext{
${ }^{40}$ La ley de gobiernos corporativos $\mathrm{N}^{\circ} 20.382$ de 2009 elevaría en un grado el presidio contemplado en el art. 61, cuando la conducta la realice quien en razón de su cargo, posición, actividad o relación, pudiere poseer o tener acceso a información privilegiada (art. 61 inc. $2^{\circ} \mathrm{LMV}$ ).

${ }^{41}$ Es interesante enfrentar el contraste entre el art. 61 y el inciso $2^{\circ}$ del art. 53, en cuanto ambos competirían por la subsunción de las manipulaciones informativas. Se trata de un problema concursal, válido también para la sede administrativa, desde que la SVS entiende que también la infracción de un precepto penal configura un ilícito administrativo. El punto será abordado derechamente en las secciones dedicadas a la reconstrucción dogmática de aquella normas (infra 2.4 y 2.6), pero vale la pena dejar sentada una idea orientadora, a modo de clave de lectura general. El razonamiento es el siguiente: si por vía del art. 59 e) la LMV contempla con pena de crimen - de hasta diez años - una conducta que en principio podría igualmente subsumirse bajo la sustantivamente menos grave figura de manipulación informativa del art. $61 \mathrm{LMV}$, ello significa que no puede atribuirse a la infracción del art. 53 un contenido de injusto "ligero". Al contrario, interpretativamente debe asignársele un contenido de injusto lo suficientemente grave como para merecer una sanción penal superior a la que procede para las ya suficientemente graves manipulaciones informativas subsumibles bajo el art. $61 \mathrm{LMV}$. Cuando en cambio se pretende vaciar de contenido el injusto del art. $53 \mathrm{LMV}$ - reconociendo como infractoras conductas no manipulativas - entonces se hace una aplicación del Título VIII inconsistente con la sistemática de la LMV.

${ }^{42}$ Todos estos instrumentos se encuentran disponibles para su consulta en los sitios web de las respectivas Bolsas.
} 
LONDOÑO, Fernando “¿Qué prohíben los artículos 52 y 53 de la Ley de Mercado

de Valores? Reconstrucción dogmática de las figuras de manipulación

de mercado en el derecho chileno".

correspondiente al Reglamento de la Bolsa Electrónica. En la columna de la derecha se indica la respectiva referencia de la LMV.

\begin{tabular}{|c|c|}
\hline $\begin{array}{l}\text { Reglamento de la Bolsa de Comercio de Santiago [Reglamento de la Bolsa } \\
\text { Electrónica de Chile] }\end{array}$ & $\begin{array}{l}\text { Equivalencia } \\
\text { LMV }\end{array}$ \\
\hline $\begin{array}{l}\text { Art. 65 [63]: "Salvo los casos permitidos por la ley, queda prohibido a los corredores } \\
\text { efectuar transacciones en valores con el objeto de estabilizar, fijar o hacer variar } \\
\text { artificialmente los precios de los mismos". }\end{array}$ & $\begin{array}{l}\text { Cfr. art. } 52 \\
\text { LMV }\end{array}$ \\
\hline $\begin{array}{l}\text { Art. 66 [64]: "Constituye infracción grave la realización de transacciones ficticias } \\
\text { respecto de cualquier valor, la participación en transacciones simuladas y la } \\
\text { realización de cualquier maniobra tendiente a alterar artificialmente las cotizaciones } \\
\text { de bolsa". * (el destacado es nuestro) }\end{array}$ & $\begin{array}{l}\text { Cfr. }{\text { inc. } 1^{\circ}} \\
\text { art. } 53 \text { LMV }\end{array}$ \\
\hline $\begin{array}{l}\text { Art. } 67 \text { [65]: "Los corredores no podrán efectuar transacciones, o inducir o intentar } \\
\text { inducir a la compra o venta de valores por medio de cualquier acto, práctica, } \\
\text { mecanismo o artificio engañoso o fraudulento". }\end{array}$ & $\begin{array}{l}\text { Cfr. inc. } 2^{\circ} \\
\text { art. } 53 \text { LMV }\end{array}$ \\
\hline
\end{tabular}

Como se advierte, los Reglamentos no innovan en lo sustantivo en las prohibiciones correspondientes al art. 52 LMV (estabilizaciones) y al inciso $2^{\circ}$ del art. 53 LMV (transacciones manipulativas e inducciones manipulativas). Con todo, se aprecia una interesante variante complementaria a la fórmula del inciso $1^{\circ}$ del art. $53 \mathrm{LMV}$ en los artículos 66 y 64 de los respectivos Reglamentos. Allí, amén de asociar la idea de "transacciones ficticias" a la de "transacciones simuladas", 43 se reemplaza la referencia a "cotizaciones ficticias" por la prohibición de "la realización de cualquier maniobra tendiente a alterar artificialmente las cotizaciones de bolsa". La referencia es de interés en la medida que representa una lectura tendencialmente acertada de la algo opaca expresión "cotizaciones ficticias" contenida en el inciso $1^{\circ}$ del art. 53 la LMV.

Como se ha anticipado en otro lugar" ${ }^{44}$, la voz "cotizaciones ficticias" cumple una función hermenéutica vital para la captación del sentido general de la prohibición, pero genera perplejidad su yuxtaposición junto a la expresión "transacciones ficticias". Los Reglamentos resuelven esa perplejidad formulando la prohibición en términos directos, justamente apuntando al sentido manipulativo de los precios. Consideradas las cotizaciones como el reflejo público (publicado) de los precios de los valores transados en la bolsa ${ }^{45}$, se capta el sentido de la prohibición legal. En efecto, la falsificación de las cotizaciones resulta perfectamente idónea para inducir a error al mercado y, desde allí, condicionar los preciosde-mercado a partir de decisiones de inversión o desinversión que descansen en dicha falsificación. Esta modalidad es por lo demás bien conocida en la literatura ${ }^{46}$ y representa

\footnotetext{
${ }^{43}$ A mi parecer esta referencia en nada ayuda al esclarecimiento del alcance de la fórmula, dada la muy debatida ambigüedad del concepto de simulación en nuestro derecho.

${ }^{44}$ Cfr. LONDOÑO, “Aproximación histórico-comparada", cit. nota n 1, p. 427.

${ }^{45}$ Este es el inequívoco sentido que le atribuye la LMV; entre otras disposiciones, considérense en particular las letras b) y d) del art. 43. Por su parte, de acuerdo a la RAE cotizar significa, en el ámbito mercantil: "Publicar en la bolsa el precio de los efectos públicos allí negociados".

${ }^{46}$ En línea con la hipótesis de painting de tape, ampliamente conocida en la literatura: cfr. las guidelines CESR 04-505b, emanadas del Comité de Autoridades Europeas Reguladoras de Valores (CESR, por su sigla en inglés), colocando esta modalidad bajo el alcance de la primera normativa comunitaria de abuso de
} 


\section{Polít. crim. Vol. 12, No 24 (Diciembre 2017), Art. 13, pp. 1106-1183. [http://www.politicacriminal.cl/Vol_12/n_24/Vol12N24A13.pdf]}

una forma radical de manipulación operativa impropia, en cuanto la falsificación no requiere ni aún una apariencia de transacción ejecutada, sino que se ejerce directamente sobre los reportes de precios.

Podría todavía argumentarse que con esta reformulación pierden valor autónomo los arts. 67 y 65 de los mismos Reglamentos (equivalentes al inciso $2^{\circ}$ del art. 53 LMV), pero estimo que se trata más de un defecto de técnica que de una decisión de incidir en la interpretación del inciso $2^{\circ}$ del art. 53. Por de pronto, lo que resulta claro es que a la idea de cotizaciones ficticias los Reglamentos de las Bolsas asocian una conducta inequívocamente manipulativa $^{47}$.

b) Manual de Operaciones de la Bolsa de Comercio de Santiago: interferencias anticompetitivas (no manipulativas per se)

La contribución de las instancias de autorregulación al esclarecimiento del Título VIII LMV se incrementa ulteriormente gracias a una disposición del Manual de Operaciones en Acciones de la Bolsa de Comercio. En su parágrafo 27.920, apartado 7.I.2, justamente dedicado a las actividades prohibidas, el Manual de Operaciones reitera las prohibiciones recién transcritas del Reglamento de la Bolsa de Comercio (arts. 65 a 67). En esto nada nuevo. Sin embargo, a las anteriores hipótesis antepone una prohibición que puede resultar de interés para la clarificación del inciso $1^{\circ}$ del art. 53 LMV; a saber, la letra a) del aludido apartado 7.I.2, conforme a la cual:

"Los corredores no pueden ponerse de acuerdo con otro corredor para que éste actuando por cuenta propia o de un tercero, le compre una determinada cantidad de acciones y posteriormente se las vuelva a vender, el mismo día o en días siguientes, al mismo precio o con leves diferencias, consiguiendo de esta manera evitar realizar una operación directa $(O D)$ y por consiguiente, eliminando la posibilidad de interferencia de otros corredores interesados en la operación." (Manual de Operaciones en Acciones de la Bolsa de Comercio, parágrafo 27.920, apartado 7.I.2, a]; la cursiva es nuestra)

Es interesante que el Manual contemple esta hipótesis separadamente. Una primera lectura podría llevar a pensar que la conducta descrita coincide con las manipulaciones que operan

mercado (Directiva 2003/6/CE de abuso del mercado, en adelante DAM 2003) y definiéndola en los siguientes términos: "Painting the tape. This practice involves engaging in a transaction or series of transactions which are shown on a public display facility to give the impression of activity or price movement in a financial instrument".

${ }^{47}$ En fin, puede ser de interés apreciar que los Reglamentos de las Bolsas asocian las prohibiciones del Título VIII LMV con la prohibición general de publicidad o propaganda falsa o engañosa a que se refiere el art. 65 de la misma ley. En efecto, a las disposiciones de los arts. 65-67 / 63-65 de los Reglamentos le sigue una prohibición que reproduce los contenidos de la citada norma de la LMV, pero específicamente referida a los corredores de valores; así, los artículos 68 y 66 de los Reglamentos disponen: "La publicidad, propaganda y difusión que por cualquier medio hagan los corredores no podrá contener declaraciones, alusiones o representaciones que puedan inducir a error, equívocos o confusión al público sobre la naturaleza, precios, rentabilidad, rescates, liquidez, garantías o cualquier otra característica de los valores que intermedien o de sus emisores.” Hay una sintonía funcional entre las disposiciones del Título VIII y la prohibición del art. 65 LMV, de modo que los Reglamentos demuestran una acertada sensibilidad al vincular en un mismo contexto unas y otras prohibiciones. 
LONDOÑO, Fernando “¿Qué prohíben los artículos 52 y 53 de la Ley de Mercado

de Valores? Reconstrucción dogmática de las figuras de manipulación

de mercado en el derecho chileno".

mediante transacciones ficticias, como lo son las compraventas concertadas o calzadas (matched orders). Con todo, si ese fuese el caso, su incorporación se avendría mejor como complemento o especificación del supuesto de prohibición general de las transacciones ficticias, contenido en la letra c) del aludido apartado del Manual y que replica los contenidos del art. 66 del Reglamento, siempre en correspondencia con el inc. $1^{\circ}$ del art. 53 LMV. ¿Por qué entonces su tratamiento separado?

Lo cierto es que una lectura más atenta revela que el Manual no pone énfasis en la idoneidad manipulativa de una operación semejante -es decir, en su capacidad para inducir a error al mercado o para transmitir señales falsas - sino en el hecho de que con ella se evita una $O D$; es decir, que con ella se elimina la posibilidad de interferencia de otros corredores interesados en la operación. Es decir, la letra a) en cuestión no describiría una conducta per se manipulativa de los precios en el mercado de valores, sino una conducta contraria a las condiciones de apertura y competitividad esperables en la intermediación de valores. Eso se reconoce con claridad si se considera que en la citada letra a) la referencia a los precios pactados o a las cantidades de acciones no se hace para significar una especial idoneidad alteradora de los precios-de-mercado. Otra lectura podría hacerse si se incluyesen referencias a la capacidad de estas operaciones para proporcionar señales falsas al mercado o cualquier otra alusión a su valencia informativa ${ }^{48}$.

Es entonces de interés notar que -estando al menos a la auto-comprensión de la Bolsa de Comercio de Santiago- un atentado semejante queda cubierto por una prohibición distinta a aquellas que proscriben las transacciones ficticias en el mercado de valores, como lo hacen el art. 53 LMV y los arts. 66 o 64 de los Reglamentos de Bolsa. Como se verá enseguida, esta lectura es compartida por las Reglas del Comité de Regulación.

c) Reglas del Comité de Regulación y Autorregulación de las Bolsas de Comercio de Santiago y Electrónica de Chile, abril de 2009. Reglas para prevenir y combatir el uso de información privilegiada y la manipulación del mercado ${ }^{49}$.

De todas las instancias de autorregulación, este documento-guía es sin duda el más iluminador. Por de pronto es el único instrumento destinado específicamente a la caracterización de la manipulación de mercado (amén del uso de información privilegiada). Dictado en 2009 tras una fase de consulta, su impulso y alcance comprende tanto a la Bolsa de Comercio de Santiago como a la Bolsa Electrónica de Chile. Constituye un recurso

\footnotetext{
${ }^{48}$ Para complementar el razonamiento con la perspectiva comparada, se advierte cuán lejos está la letra a) en cuestión de describir una transacción ficticia-manipulativa si se le compara por ejemplo con la regulación europea ya tenida a la vista, misma bajo la cual justamente se dejan subsumir en principio las operaciones manipulativas de wash sales y matched orders. Así, el art. $1^{\circ}$ a) de la DAM 2003 describe como manipulativas "transacciones u órdenes para realizar operaciones, que proporcionen o puedan proporcionar indicios falsos o engañosos en cuanto a la oferta, la demanda o el precio de instrumentos financieros (..)"; o bien el RAM 2014 que prohíbe "ejecutar una operación, dar una orden de negociación o cualquier otra conducta que: i) transmita o pueda transmitir señales falsas o engañosas en cuanto a la oferta, la demanda o el precio de un instrumento financiero o de un contrato de contado sobre materias primas relacionado con él (...)”. 49 Disponibles

http://www.bolsadesantiago.com/Normativas\%20Comite\%20Regulacion/Reglas\%20sobre\%20informaci\%C3 \%B3n\%20privilegiada.pdf [última visita octubre 2017].
} 
Polít. crim. Vol. 12, No 24 (Diciembre 2017), Art. 13, pp. 1106-1183.

[http://www.politicacriminal.cl/Vol_12/n_24/Vol12N24A13.pdf]

hermenéutico impostergable en la dilucidación del sentido del Título VIII LMV, cuanto más si se considera que:

"Las reglas contenidas en esta regulación recogen, ordenan y complementan las disposiciones legales, normativas, reglamentarias y operativas que se refieren a la materia. Además, se incorporan normas de buenas prácticas que el Comité estima de relevancia para combatir y prevenir el uso de información privilegiada y la manipulación de mercado. Para complementar las disposiciones contenidas en este documento se han estudiado regulaciones vigentes en otros países, así como casos conocidos y resueltos por tribunales nacionales y extranjeros." (Reglas. Cit,. Introducción).

En su facción se advierte muy claramente una atención especial a la regulación europea en materia de abusos de mercado ${ }^{50}$, lo que se reconoce desde ya en la decisión de afrontar en un mismo instrumento regulativo tanto el uso de información privilegiada como la manipulación bursátil.

Por lo que interesa al presente artículo, lo más destacable de la Guía del Comité es que identifica todas las prohibiciones del Título VIII con el nomen iuris "manipulación de mercado", reconociendo así su exclusivo sentido anti-manipulativo. Los ejemplos ofrecidos a propósito de cada una de las prohibiciones ratifican en general esa noción. De especial interés resultan por cierto aquellas pertinentes al art. $53 \mathrm{LMV}$.

En lo demás, la noción de manipulación bursátil que hace suya la Guía del Comité parece en términos generales adecuada, con la importante salvedad de que extiende en demasía el concepto al asociar a él prohibiciones/infracciones de carácter puramente informativas, aunque no per se anti-manipulativas. Es el caso de las disposiciones contenidas en el art. 59 letras a), c) y f) y art. 65 inc. $1^{\circ}$ LMV. Una sintonía funcional asocia dichas figuras a las manipulaciones -todas explicables como estrategias de contención de la asimetría informativa ${ }^{51}$, pero es incorrecto ver en ellas fórmulas específicamente antimanipulativas ${ }^{52}$.

La guía sigue una estructura muy clara, indicando primero las fuentes positivas, seguidas de ejemplos de conductas en principio subsumibles bajo las respectivas fuentes. En ese marco se procede a transcribir in extenso los pasajes de mayor interés, para luego ofrecer unos breves comentarios. De la sola lectura del segmento transcrito resultará clara la coincidencia entre la tesis central defendida en este trabajo y la lectura del Título VIII LMV que hace suya la Guía del Comité.

Así, puede leerse a partir de la página 15 , punto V de la Guía citada:

\section{"V. Manipulación de mercado}

\footnotetext{
${ }^{50} \mathrm{Al}$ respecto, cfr. LONDOÑO, “Aproximación histórico-comparada”, cit. nota $\mathrm{n}^{\circ} 1$, pp. 447 y ss.

${ }^{51}$ Cfr. supra nota $\mathrm{n}^{\circ} 2$

${ }^{52}$ Cfr. supra nota $\mathrm{n}^{\circ} 47$ por lo que toca al art. $65 \mathrm{LMV}$.
} 
LONDOÑO, Fernando “¿Qué prohíben los artículos 52 y 53 de la Ley de Mercado de Valores? Reconstrucción dogmática de las figuras de manipulación de mercado en el derecho chileno".

A continuación se identifican prohibiciones y deberes de actuar aplicables a los corredores y emisores, sus empleados y profesionales, en relación con conductas de manipulación de mercado:

\section{No podrán efectuar transacciones en valores con el objeto de estabilizar, fijar o hacer variar artificialmente los precios. ${ }^{53}$}

$(\ldots)$

\section{Ejemplos:}

- Las compras o ventas de acciones al cierre del mercado con la sola finalidad de alterar artificialmente el precio de cierre de las acciones y con el efecto de inducir a error a los inversores que actúan basándose en las cotizaciones de cierre.

- Las compras y ventas de una determinada acción con la sola finalidad de mostrar movimiento en su cotización.

2. No podrán efectuar transacciones o inducir o intentar inducir a la compra o venta de valores, regidos o no por la ley de mercado de valores, por medio de cualquier acto, práctica, mecanismo o artificio, ya sea que sepa, o deba razonablemente saber, que es engañoso o fraudulento. ${ }^{54}$

$(\ldots)$

Ejemplos:

- La solicitud que hace el gerente de un emisor con baja presencia bursátil a un tercero, para que ese mismo día compre acciones del emisor a un alto precio, de forma que su cotización suba artificialmente, y con la sola finalidad de liquidar un instrumento derivado sobre dichas acciones a un precio de su conveniencia.

- La recomendación de inversión en un fondo accionario que realiza un corredor, fondo que por su naturaleza involucra riesgos imprevisibles, señalando que las variables que inciden en su cotización son predecibles.

- El operador de la mesa de acciones de un corredor que pone reiteradamente órdenes de compra, pero sin ejecutarlas, con la sola finalidad de dar una impresión falsa de la existencia de una fuerte demanda.

\section{No podrán efectuar órdenes, cotizaciones o transacciones ficticias o simuladas. ${ }^{55}$} (...)

\section{Ejemplos:}

- El corredor que realiza transacciones ficticias o simuladas con su socio principal con la sola finalidad de lograr una mayor presencia de mercado.

\footnotetext{
${ }^{53}$ A esta prohibición el Documento Guía asocia expresamente las siguientes fuentes normativas "Fuentes: artículo 52 de la Ley de Mercado de Valores; artículo 3.3.2. de las Recomendaciones del Comité de Regulación; artículo 65 del Reglamento de la Bolsa de Comercio de Santiago; artículo 63 del Reglamento de Operaciones de la Bolsa Electrónica; y, artículo 37 del Manual de Derechos y Obligaciones de Corredores de la Bolsa de Comercio de Santiago." (Reglas, cit., p. 15)

${ }^{54}$ A esta prohibición el Documento Guía asocia expresamente las siguientes fuentes normativas: "Fuentes: artículo 53 inciso $2^{\circ}$ de la Ley de Mercado de Valores; artículo 67 del Reglamento de la Bolsa de Comercio de Santiago; artículo 38 del Manual de Derechos y Obligaciones de Corredores de la Bolsa de Comercio de Santiago; y, artículo 65 del Reglamento de Operaciones de la Bolsa Electrónica." (Reglas, cit., pp. 15-16).

${ }^{55}$ A esta prohibición el Documento Guía asocia expresamente las siguientes fuentes normativas: "Fuentes: artículo 53 de la Ley de Mercado de Valores; artículo 66 del Reglamento de la Bolsa de Comercio de Santiago; artículo 37 del Manual de Derechos y Obligaciones de Corredores de la Bolsa de Comercio de Santiago; y, artículo 64 del Reglamento de Operaciones de la Bolsa Electrónica.” (Reglas, cit., p. 16).
} 
Polít. crim. Vol. 12, № 24 (Diciembre 2017), Art. 13, pp. 1106-1183.

[http://www.politicacriminal.cl/Vol_12/n_24/Vol12N24A13.pdf]

- El operador de una corredora realiza transacciones ficticias si compra y vende acciones, coludido con el operador de otra corredora, pero sin la intención de realizar una transacción que altere la posición en acciones que inicialmente se tenía.

- La utilización indebida por parte de un corredor de una orden directa (OD) con la finalidad de fijar artificialmente los precios de mercado." (Reglas, cit., pp. 15-16)

Pues bien, algunos comentarios obligados.

En primer lugar debe reiterarse el acierto de la Guía del Comité al asociar las prohibiciones del Título VIII con el preciso nomen iuris "manipulación de mercado", reconociendo de este modo su exclusivo sentido anti-manipulativo.

Enseguida, por lo que atañe al menos a los primeros dos ejemplos bajo el inc. $1^{\mathrm{o}}$ del art. 53, ellos constituyen eficaces descripciones de un aspecto de la conducta prohibida, pero están todavía necesitados de una exigencia de idoneidad manipulativa, según se desprende de la propia sistemática de la Guía y conforme se requiere en prácticamente todos los ejemplos planteados.

En tercer lugar, un comentario especial merece el último de los ejemplos transcritos, atingente a la interpretación del inc. $1^{\circ}$ del art. 53 LMV:

"La utilización indebida por parte de un corredor de una orden directa (OD) con la finalidad de fijar artificialmente los precios de mercado." (Reglas, cit., p. 16. La cursiva es nuestra)

La utilización de este ejemplo revela una coincidencia con la lectura que se ha hecho de la normativa del Manual de Operaciones arriba transcrita (parágrafo 27.920, apartado 7.I.2, letra a]); a saber, que no ha de considerarse manipulativa per se -infractora del art. 53 LMV - una transgresión a la normativa en materia de órdenes directas $(O D)$ o bien un uso indebido de dicho tipo de orden, sino en la medida que pueda a la vez decirse que se realizó con la finalidad de fijar artificialmente los precios de mercado. Podría todavía plantearse moviéndonos más allá del ejemplo ofrecido por el documento-guía- que en todo caso no podrá considerarse manipulativa una operación semejante en la medida que, considerada en su objetividad, carezca de idoneidad para alterar o mover los precios-de-mercado del respectivo instrumento.

Creo que en este mismo plano se colocaría, por ejemplo, la mera infracción a una prohibición como la del art. 126 del Reglamento de la Bolsa de Comercio de Santiago (disposición que, correctamente, la Guía del Comité no incluye entre las fuentes de la prohibición ${ }^{56}$ ), allí donde establece que "no se podrán convenir operaciones al margen de la rueda y sin pregón, sino en casos expresamente previstos en el presente Reglamento". De acuerdo a lo aquí defendido -y a la luz de los citados instrumentos de autorregulación de las Bolsas- en la medida que la operación al margen de rueda y sin pregón no se realice con finalidades manipulativas y no contenga en sí misma una cualidad manipulativa del

\footnotetext{
${ }^{56}$ Cfr. supra nota al pie precedente.
} 
LONDOÑO, Fernando “¿Qué prohíben los artículos 52 y 53 de la Ley de Mercado

de Valores? Reconstrucción dogmática de las figuras de manipulación

de mercado en el derecho chileno".

precio-de-mercado del respectivo instrumento, no podrá verse en ella una infracción al art. 53 de la LMV.

El último comentario atañe al inc. $2^{\circ}$ del art. 53 LMV y a los respectivos ejemplos de la Guía. Aunque se comparte la visión de conjunto plasmada en la Guía en esta materia, a la luz de la tesis defendida en este trabajo resulta cuestionable el segundo de los ejemplos utilizados para ilustrar el contenido del inciso $2^{\circ}$ del art. 53, allí donde se alude al caso de:

"La recomendación de inversión en un fondo accionario que realiza un corredor, fondo que por su naturaleza involucra riesgos imprevisibles, señalando que las variables que inciden en su cotización son predecibles.” (Reglas. cit., V.3, p. 16)

Como puede advertirse, es mayúscula la asimetría entre este supuesto y los demás que la Guía considera bajo la rúbrica "manipulación de mercado"; y es que el ejemplo aquí cuestionado - cuya subsunción no resulta a priori descartable bajo la letra a) del art. 59 LMV - se ubica mejor en el marco de una modalidad de fraude mediante engaño, dirigido a una tutela preferentemente individual-patrimonial (en lugar de la tutela institucional o supra-individual que caracteriza a las figuras de manipulación). ${ }^{57}$ Aquí se han ofrecido y se ofrecerán razones para tomar distancia de aquella lectura del art. 53 LMV.

\subsubsection{Pronunciamientos doctrinarios en nuestro medio}

Los pronunciamientos doctrinarios sobre las disposiciones del Título VIII LMV son $\operatorname{acotados}^{58} \mathrm{y}$, con la excepción de un trabajo anterior del suscrito ${ }^{59}$, no se han volcado en trabajos dedicados especialmente al tratamiento de dicho título. Lo anterior no desmerece sin embargo su relevancia. Por de pronto, es de sumo interés que todos los autores coincidan en asociar a las prohibiciones un alcance específicamente anti-manipulativo, y que no vean en ellas un sentido de protección alternativo (directamente patrimonial, por ejemplo).

\footnotetext{
${ }^{57}$ En lo demás, puede consultarse lo sostenido en LONDOÑO, “Aproximación histórico-comparada", cit. nota $\mathrm{n}^{\circ} 1$, pp. 432 y ss., especialmente al tratar la comparación con la Regla 10b-5 del derecho estadounidense (refutando una posible lectura del inc. $2^{\circ}$ del art. 53 que dé cabida en su seno a ese tipo de modalidades de fraude por engaño).

${ }^{58} \mathrm{Al}$ margen de este recuento doctrinario, cfr. MANRÍQUEZ R., Juan Carlos, "Responsabilidad penal por el producto financiero defectuoso. Especial referencia a la creación, colocación en el mercado, gestión de asesoramiento e intermediación de PFD como formas de intervención criminal", Revista de Ciencias Penales, Sexta Época, Vol. XLII, No 3 (2015), pp. 75-86, trabajo al que no se dedica espacio en el cuerpo de este artículo por estimarse que su toma de posición no ofrece todavía suficientes bases de certeza. En efecto, si bien el trabajo citado se ocupa de un supuesto de hecho de eventual interés para las prohibiciones aquí analizadas (que parece dejarse describir como una forma de fraude por venta de productos financieros defectuosos), la solución propuesta por el autor afirma primero una tipicidad bajo la letra e) del artículo 59 LMV (por momentos genéricamente citado [cfr. op. cit. p. 77], pero en cualquier caso colocado en el mismo plano argumentativo que la letra g] del art. 59, el art. 61 y el 61 bis LMV [cfr. op. cit. p. 83], con lo que se pierde la especificidad de la tácita propuesta hermenéutica del autor), para terminar concluyendo que el supuesto de hecho quedaría cubierto (¿sólo?) por el tipo de estafa (con referencia a los arts. 467 y 468 CP: cfr. op. cit. p. 85).

${ }^{59}$ LONDOÑO, “Aproximación histórico-comparada”, cit. nota n 1 .
} 


\section{Polít. crim. Vol. 12, No 24 (Diciembre 2017), Art. 13, pp. 1106-1183. [http://www.politicacriminal.cl/Vol_12/n_24/Vol12N24A13.pdf]}

Históricamente, la primera toma de posición corresponde a Alfredo Etcheberry ${ }^{60}$, quien ofrece una interpretación de los arts. 52 y 53 LMV a propósito del tratamiento del art. 285 CP de alteración de precios en la imprescindible Parte Especial de su Derecho Penal. No puede sino admirarse la destreza con la que, en un contexto manualístico, este autor conecta un tipo hasta hace poco tiempo "invisibilizado" del CP original ${ }^{61}$ con aquellas dos dispersas prohibiciones de la LMV. Para nuestros propósitos, bastará con decir que Etcheberry concluye que aquellas disposiciones se encuentran en concurso aparente con el art. $285 \mathrm{CP}$ :

"son (...) prescripciones más minuciosas que las del Código [Penal], pero que se refieren a la misma finalidad: alterar artificialmente el precio resultante de las libres transacciones del mercado de valores" ${ }^{\prime 62}$.

La siguiente toma de posición se debe a Verónica Rosenblut ${ }^{63}$, en el marco de un comentario a la sentencia del ya aludido caso Schwager. El trabajo es de especial interés en cuanto se pronuncia sobre los alcances del inciso $2^{\circ}$ del art. $53 \mathrm{LMV}$. Así, puede leerse que:

“(...) es precisamente a partir de la prohibición establecida en el inciso segundo del mencionado artículo 53, que es posible sostener la regulación en nuestro ordenamiento jurídico de la figura conocida en doctrina comparada como "manipulación bursátil" o como manipulación de los precios de los instrumentos financieros cotizados en bolsa" (op. cit. p. 187)

Enseguida se confirma esta idea, aclarándose la lesividad de la figura y el sentido de la inducción a que se refiere ella:

"Establecido (...) que por inducción ha de entenderse (...) injerencia, resulta posible reconocer el carácter de delito de manipulación bursátil a la figura establecida en el inciso segundo del art. 53 (...), por cuanto esa injerencia que representaría la inducción a que hace referencia la norma, implicaría una manipulación, es decir, en su acepción genérica, ejercer una forma de control o dominio sobre una determinada realidad, la que se considera negativa, en la medida que esa injerencia o control tenga un efecto distorsionador en el mercado (...)" (op. cit. pp. 187-188)

Por su parte, en un trabajo de 2013 de autoría del suscrito se anticipaban claves de lectura sobre el Título VIII LMV, si bien sólo marginalmente ${ }^{64}{ }^{65}$. Una toma de posición directa se

\footnotetext{
${ }^{60}$ ETCHEBERRY, Alfredo, Derecho Penal. Parte Especial, Tomo IV, 3 a ed., Santiago: Editorial Jurídica de Chile, 1998, p. 281.

${ }^{61}$ Referencias al "renacimiento" del art. 285 CP a propósito del denominado caso "Farmacias" - en el marco del tratamiento de los atentados contra la libre competencia - se encuentran ya en LONDOÑO, "Aproximación histórico-comparada", cit. nota $\mathrm{n}^{\circ} 1$, pp. 403 y ss.

${ }^{62}$ ETCHEBERRY, Derecho Penal, cit. nota $\mathrm{n}^{\circ}$ 60, p. 281.

${ }^{63}$ ROSENBLUT, "El caso Schwager", cit. nota no 32, pp. 185-209.

${ }^{64}$ Cfr. LONDOÑO, "Ilícito de manipulación", cit. nota $\mathrm{n}^{\circ} 2$ : una toma de posición general sobre el sentido global de las disposiciones del Título VIII se aprecia ya en la apertura del citado trabajo, comprendiendo los arts. 52, 53 y 61 bajo la órbita de la categoría de la manipulación bursátil (p. 66, nota 1 de aquel artículo); luego, profundizando en ese planteamiento general, en el mismo trabajo se tomó posición sobre el alcance de las figuras del Título en comento, asociándolas en cada caso a las tipologías fácticas o de derecho comparado abordadas allí; entre otras, de especial interés resultan las notas 114, 116, 118 y 123 del citado trabajo.
} 


\section{LONDOÑO, Fernando “¿Qué prohíben los artículos 52 y 53 de la Ley de Mercado de Valores? Reconstrucción dogmática de las figuras de manipulación de mercado en el derecho chileno".}

asume ya en un trabajo sucesivo de $2015^{66}$, si bien todavía dedicado a ofrecer un marco interpretativo general, antes que a una reconstrucción detallada de los arts. 52 y 53 . A ese esfuerzo se dedica justamente lo que sigue del presente artículo.

En fin, aunque no lidiando directamente con los arts. 52 y 53 LMV, con distintos enfoques y profundidad, entienden también en clave anti-manipulativa las prohibiciones del Título VIII LMV Gonzalo García Palominos (abordando transversalmente las tipologías del art. 59 LMV), Héctor Hernández (proponiendo una interpretación para el tipo de la letra a] del art. 59 LMV) y Jaime Winter (ofreciendo una panorámica general del estado del derecho penal empresarial en Chile), los tres con trabajos publicados durante el primer semestre de $2017^{67}$, al cierre de la revisión del presente artículo.

${ }^{65}$ Una lectura del Título VIII compatible con la aquí defendida está también implícita en el informe del suscrito en materia de delitos del mercado de valores, solicitado por la Comisión Asesora Presidencial para la elaboración de un anteproyecto de nuevo Código Penal (Ministerio de Justicia, 2013, inédito). Debe notarse, por otra parte, que el Anteproyecto en cuestión daría lugar al Mensaje presentado por el Ejecutivo en marzo de 2014 (Boletín $\mathrm{N}^{\circ}$ 9.274-07), en cuyo cuerpo se incorporan dos figuras de manipulación bursátil (arts. 366 y 367) las que, aunque con ciertas diferencias, parecen adscribir a la sistemática más en boga en materia de manipulaciones bursátiles, fundamentalmente de cuño europeo.

${ }^{66}$ Cfr. LONDOÑO, “Aproximación histórico-comparada", cit. nota n ${ }^{\circ} 1$, pp. 390 y ss.

${ }^{67}$ Cfr. GARCÍA, Gonzalo, "Equivalentes funcionales en los delitos económicos. Una aproximación de solución ante la falta de lesividad material en delitos de presentación de información falsa al mercado de valores", Polít. crim. Vol. 12, $\mathrm{N}^{\mathrm{o}} 23$ (Julio 2017), Art. 6, pp. 151-206, disponible en: http://www.politicacriminal.cl/Vol_12/n_23/Vol12N23A6.pdf, passim, asociando el injusto del art. 53 al del art. 61 LMV. De especial interés resulta su distinción entre "manipulación de mercado" (arts. 53 y 61) y "manipulación de precios" (art. 52), que lastimosamente sólo enuncia (cfr. op. cit., p. 152), pero que puede dejarse describir como una distinción entre manipulaciones que ocurren a través del mercado (injerencia indirecta) y manipulaciones que se vuelcan directamente sobre los precios (injerencia directa), ya adelantada en LONDOÑO, "Ilícito de manipulación", cit. nota $\mathrm{n}^{\circ}$ 2, pp. 103 y ss. y LONDOÑO, "Aproximación histórico-comparada", cit. nota $\mathrm{n}^{\circ} 1$, pp. 456 y ss. Por su parte, cfr. HERNÁNDEZ, Héctor, "La necesaria relevancia para el precio de los valores de la información falsa del art. 59 letra a) de la Ley de Mercado de Valores", Revista de Derecho de la Pontificia Universidad Católica de Valparaíso XLVIII (Valparaíso, Chile, 1er semestre de 2017), pp. 105-131, proponiendo una preliminarmente atendible interpretación restrictiva para el tipo de la letra a) del art. $59 \mathrm{LMV}$, conforme a un criterio de relevancia de la información entregada al público, de modo que sólo cuente como típica aquella con potencial de incidencia en el preciode-mercado. En ese contexto, el autor ubica la figura en el marco de las manipulaciones informativas "en sentido amplio" o cuanto menos "en la antesala de dichas formas de manipulación" (cfr. pp. 112, 117 y 124), equiparándola en su cobertura tanto al art. 53 (motejado como "oscuro") como al art. 61, estimado como figura residual de manipulación informativa (cfr. pp. 108, 112 y 117). No puede ser este el lugar para una toma de posición detallada sobre el mérito de tal interpretación del art. 59 a) LMV - en lo demás infra nota ${ }^{\circ}$ 143 - pero en mi opinión lleva razón Hernández al ofrecer un criterio de relevancia informativa para restringir el de otro modo incontrolable y contradictorio alcance de la figura, antes que nada de cara a supuestos de afectación de intereses de fiscalización administrativa. Hay que decir sin embargo que la tesis tiene un impacto que va más allá de la sola cuestión relativa al objeto de la conducta: y es que si sólo cuenta como información típica del art. 59 a) aquella relevante para la cotización de los valores (como propone Hernández), entonces queda de hecho limitado el círculo de sujetos activos a aquellos que actúan desde o por cuenta de un emisor de valores de oferta pública, con exclusión de cualquier otro tipo de sujetos regulados bajo el sistema de la LMV. En efecto, desde un contexto informativo distinto a aquel que pesa sobre el emisor de valores de oferta pública, no se explica cómo es que la información proporcionada (en cumplimiento de un deber interno al sistema de mercado de valores, a la luz de la correcta lectura que Hernández hace de la fórmula "para los efectos de lo dispuesto en esta ley") podría incidir en las cotizaciones de valores de oferta pública (aquellos valores de interés para los efectos de la LMV). ¿Podría acaso tener impacto sobre las 
Polít. crim. Vol. 12, № 24 (Diciembre 2017), Art. 13, pp. 1106-1183. [http://www.politicacriminal.cl/Vol_12/n_24/Vol12N24A13.pdf]

\section{Reconstrucción dogmática del Título VIII LMV: sobre el alcance de los arts. 52 y 53 (a la vez, una propuesta sobre el sentido del art. 61)}

Con lo dicho hasta aquí (y apoyándonos en las tesis defendidas en un trabajo precedente ${ }^{68}$ ), se está finalmente en condiciones de ofrecer una propuesta de interpretación sistemática y detallada para el Título VIII LMV, especialmente para su problemático art. 53.

Vale la pena transcribir una vez más las disposiciones en comento, antes de proceder al análisis:

El inciso $1^{\circ}$ del art. 52 reza:

"Es contrario a la presente ley efectuar transacciones en valores con el objeto de estabilizar, fijar o hacer variar artificialmente los precios".

El art. 53, por su parte:

"Es contrario a la presente ley efectuar cotizaciones o transacciones ficticias respecto de cualquier valor, ya sea que las transacciones se lleven a cabo en el mercado de valores o a través de negociaciones privadas.

cotizaciones de valores una información falsa estrictamente atingente al status financiero o comercial de un intermediario, una Bolsa, una clasificadora de riesgo o una auditora? Tal información será ciertamente relevante para valorar el patrimonio y giro de tales entidades, y por tanto de interés para sus accionistas, acreedores y clientes (en su caso falsedad contable o societaria, qué duda cabe), pero de ordinario carecerá de relevancia para las cotizaciones de unos valores emitidos por terceros (salvo por cierto el raro caso de información que se relacione a situaciones de riesgo de iliquidez sistémica, como podría ser el supuesto de información relativa al colapso de una bolsa o de un mercado). El razonamiento anterior es válido por cierto en la medida que se otorgue a la voz cotización de valores el sentido que le da la LMV, estrechamente vinculado a la idea de oferta pública (cfr. supra nota $\mathrm{n}^{\circ} 45$ en lo demás). Pues bien, todo parece indicar que la tesis de Hernández es plausible (también) en lo que toca a esta indirecta restricción del círculo de sujetos activos, por más que el punto merezca una reflexión más detenida. Y es que, en mi opinión, es preciso examinar detenidamente si acaso la lógica regulativa de la LMV no plantea supuestos intermedios de relevancia: inferiores al ciertamente relevante interés de las cotizaciones de valores, pero superiores al mero interés de fiscalización de la autoridad. En este contexto, mi coincidencia con la tesis de Hernández para el art. 59 a) - reflejada también infra en la nota $\mathrm{n}^{\circ} 143$ - ha de estimarse como toma de posición provisoria. En cualquier caso, sirvan las observaciones anteriores para poner en evidencia una consecuencia no del todo explicitada en la tesis de Hernández, algo que - a mi modo de ver - permite apreciar hasta qué punto resulta crucial aclarar la colisión de normas que plantea la aparentemente más acotada letra f) del art. 59 LMV (sobre lo cual, cfr. op. cit., pp. 107-108). En fin, y sin perjuicio de lo anterior, por lo que toca a la menos relevante cuestión sobre el nomen iuris de la figura del art. 59 a) (cfr. op. cit, pp. 112 y 113), coincido con Hernández en advertir que con su asociación a la noción de manipulación informativa se corre el riesgo de favorecer una injustificada lectura ulteriormente restrictiva; lo anterior, no tanto imponiéndole exigencias de resultado, que resultan clamorosamente fuera de lugar, como calificándola en su faz subjetiva, exigiendo un propósito manipulativo (algo que en mi opinión sí ha de hacerse respecto del art. 53). Pero por eso mismo era preferible eludir ese nomen iuris. En fin, para cerrar el listado de publicaciones recientes, cfr. WINTER, Jaime, "Panorama del Derecho Penal Empresarial en Chile", en: AMBOS, Kai et Al. (Coords.), Reformas Penales, Santiago: Der Ediciones, 2017, pp. 87-119, p. 105, someramente identificando en la letra e) del art. 59 - en relación con los arts. 52 y 53 - y en el art. 61 LMV figuras de manipulación bursátil, para englobar las demás hipótesis del art. 59 LMV bajo la noción de falsedades en informaciones entregadas al mercado.

${ }^{68}$ Cfr. LONDOÑO, “Aproximación histórico-comparada”, cit. nota nº 1, passim. 
LONDOÑO, Fernando “¿Qué prohíben los artículos 52 y 53 de la Ley de Mercado

de Valores? Reconstrucción dogmática de las figuras de manipulación

de mercado en el derecho chileno".

Ninguna persona podrá efectuar transacciones o inducir o intentar inducir a la compra

o venta de valores, regidos o no por esta ley, por medio de cualquier acto, práctica, mecanismo o artificio engañoso o fraudulento".

\subsection{Sentido general de protección del Título VIII LMV}

En otro lugar -a partir de un estudio comparado, pero también en base a consideraciones sistemáticas válidas para nuestra LMV- se han dado razones para descartar una lectura que vea en el Título VIII un sentido dirigido a la (directa) tutela de intereses individualespatrimoniales, ya bajo formas de engaño, ya bajo formas de administración desleal ${ }^{69}$. Por su parte, los argumentos históricos y sistemáticos desarrollados en el apartado anterior (1) han buscado demostrar la plausibilidad de aquella tesis, ahora con recurso a elementos de derecho interno. Toca ahora utilizar parte de aquel material para ofrecer una reconstrucción dogmática de los arts. 52 y 53 LMV. En su faz positiva, la reconstrucción buscará confirmar el sentido anti-manipulativo del Título VIII. En su faz negativa, buscará refutar lecturas que vean en el inc. $1^{\circ}$ del art. 53 una fórmula emparentada con el contrato simulado perjudicial para terceros (como el del art. $471.2 \mathrm{CP}$ ), o en el inc. $2^{\circ}$ del art. 53 una forma de estafa de inversión, una suerte de administración desleal en perjuicio del patrimonio de inversionistas particulares o cualquier otra figura de defraudación de alcance directamente patrimonial-individual $^{70}$.

\footnotetext{
${ }^{69}$ Cfr. LONDOÑO, “Aproximación histórico-comparada", cit. nota $\mathrm{n}^{\circ} 1$, passim., aunque especialmente pp. 442-447 para la refutación de una posible lectura del art. 53 LMV, "pseudo-asimiladora" de la Regla 10b-5 del derecho federal estadounidense. En aquel trabajo (pp. 445-446) se dio cuenta de la doctrina sentada por la Corte Suprema de los Estados Unidos en Santa Fe Industries, Inc. V. Green, 430 U.S. 462 (1977). Conforme a ella, la Regla 10b-5 ha de leerse bajo un paradigma de transparencia informativa (disclosure), exigiéndose una forma de engaño (deceit) como elemento ineludible de la infracción. De ahí que - siempre de acuerdo a Santa Fe Industries - supuestos claros de corporate mismanagement o administración desleal societaria (típicamente en perjuicio de accionistas minoritarios) queden excluidos de la protección federal por vía de la Regla 10b-5 (resultando tutelados únicamente bajo el derecho de sociedades, de competencia estatal, muy comúnmente bajo Delaware). Ese estado de la cuestión persiste y, en lo sustantivo, no se ve alterado por la oblicua solución ofrecida por la Corte Federal de Apelaciones del 2do. Circuito en Goldberg. v. Meridor, 567 F.2d 209 (2d Cir. 1977, certiorari denegado, 434 U.S. 1069 [1978]), conforme a la cual cuenta como engaño (para efectos de la Regla 10b-5) aquel que impide a los accionistas minoritarios hacer valer un remedio disponible en el derecho estatal de sociedades. Al respecto, con detalle, cfr. PARK, James J., "Delaware and Santa Fe" (April 5, 2017), en: Delaware's Dominance in Corporate Law (Cambridge University Press, de próxima publicación), UCLA School of Law, Law-Econ Research Paper No. 17-06, pp. 17-18 (disponible en SSRN: https://ssrn.com/abstract=2947225); otro tanto, en COX et Al, Securities Regulation, cit. nota $\mathrm{n}^{\circ} 4$, pp. 769-770. Para una profundización sobre el debate en Estados Unidos, ubicado en el marco de la problemática distinción entre esferas de tutela del derecho societario (Corporate Law, de competencia estatal) $\mathrm{y}$ del derecho de mercado de valores (Securities Law, de competencia federal), cfr. de reciente PARK, James J., "Reassessing the Distinction Between Corporate and Securities Law", UCLA L. Review, Vol. 64, Nm. 1 (2017), pp. 116-182, passim, reivindicando una delimitación en línea con la doctrina Birnbaum (formulada en 1952 por la Corte Federal de Apelaciones del 2do. Circuito: Birnbaum v. Newport Steel Corp., 193 F.2d 461 [2d Cir. 1952]), y distinguiendo entre la tutela de los inversionistas en tanto propietarios (competencia del derecho societario) y la protección de los inversionistas en tanto negociadores (traders) con valores (competencia del derecho federal de mercado de valores, en este caso eventualmente vía Rule 10b-5).

${ }^{70}$ Lo anterior, sin perjuicio de la legítima objeción que puede levantarse a propósito de la amplitud del objeto material cubierto por el inc. $2^{\circ}$ del art. 53 (cfr. especialmente infra 2.4.1.d, pero también infra 2.4.2.c., haciéndose cargo de una lectura alternativa, "patrimonialista").
} 
Polít. crim. Vol. 12, № 24 (Diciembre 2017), Art. 13, pp. 1106-1183.

[http://www.politicacriminal.cl/Vol_12/n_24/Vol12N24A13.pdf]

El sentido de protección del Título VIII ha de hallarse, en cambio, en la prohibición de la manipulación como forma de abuso de mercado, en cuanto lesionadora del mecanismo de formación de los precios-de-mercado. El sentido de protección coincide con la tutela del propio mercado regulado de oferta pública de valores, en cuanto dimensión institucionalizada a través de la cual se distribuyen los recursos financieros en nuestra economía, desde los ahorrantes hacia los emisores solicitantes de los recursos (conexión ahorro-inversión), con los consecuentes beneficios macroeconómicos que una correcta distribución supone ${ }^{71}$.

Nótese que esta perspectiva se halla en sintonía con las finalidades de un mercado de valores, así como elocuentemente fueron reconocidas en el Mensaje de S.E. el Presidente de la República Sr. Patricio Aylwin al proyecto de ley que introduciría las primeras reformas importantes a la LMV (Boletin 909-05 de 27 de enero de 1993, proyecto que fructificaría en la ley $\mathrm{N}^{\circ} 19.301$ de 1994):

"El objetivo básico de las reformas que se proponen, se enmarca en la necesidad de profundizar y modernizar el mercado de capitales chileno, especialmente en lo que dice relación con el mercado de valores y el rol que desempeñan en el mercado los principales inversionistas institucionales. En este sentido, es conveniente recordar la importancia que tiene un mercado de valores y el hecho que funcione en forma adecuada, con transparencia y profundidad, ya que ello hace posible que los recursos de la economía sean asignados eficientemente en el proceso de ahorro-inversión, aspecto clave para el incremento de la capacidad productiva del país y que, en definitiva, permite la mantención de un crecimiento alto, sostenido y con estabilidad en precios." (Mensaje, proyecto de ley Boletín 909-05 de 27 de enero de 1993).

Una serie de consecuencias interpretativas se desprenden a partir de la ubicación del Título VIII en el radio de protección arriba descrito y que -formulado en negativo- se deja también caracterizar como meta-patrimonial. Más adelante se detallarán aquellas consecuencias, pero puede ser de utilidad adelantar al menos una, para que de partida se aprecie que la identificación del sentido de protección no representa un esfuerzo hermenéuticamente estéril. Pues bien, habida cuenta de la dimensión meta-patrimonial del injusto manipulativo, puede decirse que éste no se configura allí donde se predique la supuesta artificiosidad del precio-singular pactado para una o más transacciones con valores (con eventual resultado de perjuicio patrimonial-individual), sino sólo cuando dicha artificiosidad pueda predicarse -como objetivo intentado- respecto del precio-de-mercado pretendido.

Dicho en términos más directos: no ha de considerarse artificiosa (o típicamente manipulativa, en los términos de nuestro art. 53 o de otro de cuño semejante) una transacción por el solo hecho de que ésta se ejecute a un precio tendencialmente anómalo o fuera del nivel de mercado (aunque ello pueda constituir un indicio de manipulación, pueden concurrir necesidades de desinversión, liquidez u otras -lícitas o ilícitas- que

${ }^{71}$ Véase al respecto, para más detalles, incluyendo la necesaria distinción entre mercado primario y secundario, LONDOÑO, "Ilícito de manipulación", cit. nota ${ }^{\circ} 2$, pp. 72 y ss. con más detalle y bibliografía sobre el particular. Véase por otra parte la discusión que abre en este plano la amplitud del objeto material incluido en el inc. $2^{\circ}$ del art. 53 (cfr. especialmente infra 2.4.1.d). 
LONDOÑO, Fernando “¿Qué prohíben los artículos 52 y 53 de la Ley de Mercado de Valores? Reconstrucción dogmática de las figuras de manipulación de mercado en el derecho chileno".

expliquen el precio aceptado), sino sólo si con dicha transacción-a-precio-fuera-demercado se pretende alcanzar o conseguir un precio-de-mercado anómalo o artificial. En este sentido, cuando se alude a un precio artificioso se quiere aludir a un precio-demercado manipulado, y no a un mero precio-de-transacción anómalo. Se comprende que de otro modo toda transacción realizada a un precio-fuera-de-mercado sería sin más considerada manipulativa (porque "artificiosa"), lo que por cierto resulta un despropósito sin precedentes en ningún modelo comparado ${ }^{72}$.

Para cerrar este apartado introductorio, servirá anticipar que una atención especial habrá de prestarse a las (problemáticas) referencias que el art. 53 hace a las negociaciones privadas (como medio manipulativo de acuerdo al inc. $1^{\circ}$ ) o a los valores no regidos por la LMV (como objeto de la conducta en el inc. $2^{\circ}$ ). Esas referencias -sobre todo la segunda de ellaspodrían llevar a pensar que la esfera de protección se extiende más allá (o más acá) del mecanismo de formación de precios en un mercado regulado de oferta pública de valores $^{73}$. Se ofrecerán claves de lectura en su momento, a propósito del tratamiento de aquellos elementos en el art. 53 (cfr. especialmente infra 2.3 y 2.4.1.d]).

\subsection{Primer planteamiento base: sobre la unidad de propósito general y la relación (complementaria) entre el art. 52 y el art. 53 LMV}

Como se ha defendido aquí y en un trabajo precedente ${ }^{74}$, hay buenas razones históricas y sistemáticas para una lectura que coordine los contenidos del art. 53 con los del art. 52 del mismo Título VIII (además del art. 61 LMV, sobre el que más abajo se tomará posición). Es decir, una lectura que las conciba como fórmulas complementarias, dirigidas a satisfacer una misma finalidad: la prohibición de toda forma de manipulación de los precios del mercado de oferta pública de valores.

De este modo, mientras el art. 52 prohibiría especialmente aquel tipo de manipulación que opera directamente sobre los precios-de-mercado (sobre la base de transacciones disruptivas o sobre el ejercicio de un poder de mercado), el art. 53 -en sus dos incisosprohibiría aquellas manipulaciones que operan sobre los precios-de-mercado indirectamente, específicamente a través de la injerencia en los presupuestos cognitivos de inversionistas en el mercado (mediante transacciones o informaciones que actúan como formas de engaño $)^{75}$.

\footnotetext{
${ }^{72}$ Lo mismo ha de decirse -y con mayor razón- respecto de una transacción realizada a un precio-demercado, si bien carente de una racionalidad de inversión o desinversión (por ejemplo una transacción realizada por razones contables o tributarias), con tal que ella no se realice con la finalidad de alcanzar o conseguir un determinado precio-de-mercado.

${ }^{73}$ Advirtiendo esta problemática, en el marco del tratamiento del delito de uso de información privilegiada, GARCÍA, Gonzalo, "La idealización y la administrativización de la punibilidad del uso de Información Privilegiada. Un análisis de los discursos penales en la doctrina chilena", Política criminal Vol. 10, $\mathrm{N}^{\circ} 19$ (Julio 2015), Art. 5, pp. 119-158, disponible: http://www.politicacriminal.cl/Vol_10/n_19/Vol10N19A5.pdf, passim.

${ }^{74}$ Cfr. LONDOÑO, “Aproximación histórico-comparada”, cit. nota ${ }^{\circ} 1$, passim.

${ }^{75}$ Para este punto y los sucesivos, cfr. LONDOÑO, "Ilícito de manipulación", cit. nota no 2, pp. 104-106. Véase en lo demás LONDOÑO, "Aproximación histórico-comparada", cit. nota n 1, pp. 56 y ss. (apartado III.2).
} 
Polít. crim. Vol. 12, № 24 (Diciembre 2017), Art. 13, pp. 1106-1183.

[http://www.politicacriminal.cl/Vol_12/n_24/Vol12N24A13.pdf]

Dicho en términos sintéticos, mientras el art. 52 es especialmente comprensivo de manipulaciones de precios ejercidas en el mercado, el art. 53 hace lo propio con manipulaciones ejercidas a través del mercado.

Al primer grupo pertenecen las manipulaciones operativas propias (única tipología que supone actuación directa sobre los precios), mientras al segundo grupo pertenecen todas las formas de manipulación informativa (necesariamente de actuación indirecta sobre los precios), pero también aquellas manipulaciones operativas impropias, esto es, aquellas que involucran transacciones manipulativas cuyo mecanismo de actuación supone la "contribución" (instrumentalizada o bajo engaño) de terceros inducidos a error por la apariencia de dichas transacciones. Nótese que las manipulaciones operativas impropias se parecen a las manipulaciones informativas en cuanto, al igual que ellas, resultan eficaces bajo un presupuesto de transmisión de información (y por tanto de injerencia indirecta); aunque no "descarnadamente", como en el caso de la manipulación puramente informativa, sino a través de la valencia informativa de las transacciones de que se sirve.

\subsubsection{Art. 52 LMV (además de una nota relativa a las manipulaciones en el mercado de derivados)}

Profundizando en lo anterior, puede decirse que la tipología que se condice con el primer mecanismo de manipulación (comprendido por el art. 52) es la manipulación operativa o transaccional, a la que aquí se agrega el adjetivo propia para indicar que en ellas son las mismas transacciones u operaciones realizadas por el agente manipulador las que aspiran a alcanzar el precio-de-mercado buscado, $\sin$ una necesaria (aunque igualmente posible o imaginable) intervención de terceros activos en el mercado (instrumentalizados o inducidos en error); esto es, la alteración del precio-de-mercado se verificaría por el solo accionar del agente manipulador, quien ejerce un poder de mercado efectivo (real, no fingido ni aparente) en cuanto se coloca él mismo como oferente o demandante del título respectivo, según sea el sentido de su tentativa de manipulación:

"Aquí ya no [necesariamente] hay un condicionamiento de la conducta de terceros [mediante engaño: injerencia indirecta]; simplemente se toma una posición de cara a una conducta libre o pre-ordenada de un tercero (contraparte en la operación), con miras a alcanzar un determinado nivel de precio. Es decir, se interviene en el mercado y se ejerce un poder en [aquél] con miras a la modificación de un precio. Así, se compra o se vende en el mercado de manera de conducir el precio hasta el nivel deseado" $"$.

La alteración o injerencia sobre el precio-de-mercado puede buscarse por múltiples razones ulteriores, todas irrelevantes bajo este título (finalidades lucrativas o de offsetting, contables o contractuales ${ }^{77}$, por ejemplo). Lo único relevante bajo este título es que concurra una finalidad de alteración o injerencia (directa) sobre el precio-de-mercado, de otro modo no

\footnotetext{
${ }^{76}$ LONDOÑO, "Ilícito de manipulación”, cit. nota n 2, p. 106.

${ }^{77}$ Cfr. LONDOÑO, "Ilícito de manipulación", cit. nota $n^{\circ} 2$, p. 88.
} 


\section{LONDOÑO, Fernando “¿Qué prohíben los artículos 52 y 53 de la Ley de Mercado de Valores? Reconstrucción dogmática de las figuras de manipulación de mercado en el derecho chileno".}

puede sostenerse que la conducta sea típica a la luz del art. $52 \mathrm{LMV}^{78}$. Un ejemplo lo ofrece el siguiente supuesto de manipulación operativa propia:

Piénsese en el caso del sujeto que, con miras a manipular hacia la baja el precio-demercado de cierre de año de un determinado valor, realiza en el último día hábil de diciembre agresivas ventas sobre el título, a precios decrecientes. Supongamos que por razones contables y contractuales se beneficie de ello, porque por ejemplo figura como contraparte de una opción de venta de esos valores, ejercible justamente al precio de cierre del respectivo año ${ }^{79}$. De este modo una baja siquiera sutil en el precio-demercado podrá reportarle importantes ganancias contables y contractuales. El manipulador estará dispuesto a realizar esas ventas a pérdida, pues mayor ventaja obtendrá con la baja en el precio de cierre. Recuérdese que la compra de los títulos figura entre sus obligaciones, en el pasivo. Al cierre del año podrá entonces contabilizar un mejor pasivo ${ }^{80}$.

Nótese que, a propósito del art. 52, la Guía del Comité de Autorregulación (cfr. supra 1.2.2.c]) cita un ejemplo sintético que iría en esta dirección, si bien se asume allí que el precio de cierre funciona como factor de engaño. Esto último parece colocarnos frente a una manipulación cuyo mecanismo de injerencia es doble: directo, por lo que se refiere a alcanzar los precios de cierre; pero además indirecto, desde que con dicho precio de cierre se busca inducir a error al mercado y con ello alterar los precios ulteriormente. Así:

"Las compras o ventas de acciones al cierre del mercado con la sola finalidad de alterar artificialmente el precio de cierre de las acciones y con el efecto de inducir a error a los inversores que actúan basándose en las cotizaciones de cierre." (Reglas, cit., V.1, p. $15)$.

\footnotetext{
${ }^{78}$ Mucho menos si lo que se "altera" o se considera "artificioso" es el precio-singular de una determinada negociación o transacción: por eso se ha insistido aquí que sólo el precio-de-mercado constituye objeto de la manipulación (cfr. supra 2.1).

79 Incentivos semejantes surgen en general con instrumentos derivados. Por ejemplo, piénsese en los denominados warrant-put, instrumentos derivados que otorgan a su titular un derecho de venta del valor subyacente a un determinado precio previamente acordado. Los warrant se emiten para garantizar el rendimiento de una determinada inversión en valores subyacentes; de este modo si el precio-de-mercado del valor subyacente ha bajado (por debajo del precio pactado), el tenedor del warrant puede o bien ejercer su derecho de venta de los valores subyacentes al mayor valor o bien vender los warrant al emisor (con la respectiva ganancia), mismo que de este modo queda liberado de su obligación de comprar los subyacentes al mayor valor. Se comprende entonces que el emisor obligado a comprar los warrants tendrá un incentivo para que su precio baje, reflejando con ello un mejor resultado. Esto habría sido justamente lo que sucedió en el muy conocido caso italiano Banca Intesa BCI: v. Sentenza di proscioglimento, GIP Tribunale di Milano, 3 de octubre de 2005. De acuerdo a las estimaciones de la CONSOB, autoridad del sector bursátil en Italia, estas operaciones le habrían reportado a Banca Intesa un mejor resultado de entre 20 a 70 millones de euros por concepto de menor valor de las obligaciones. En lo demás, de interés resultan los casos contract-based reportados por THEL, " $\$ 850,000 "$, cit. nota $n^{\circ} 4$.

${ }^{80}$ Naturalmente sin que pueda argumentarse por ello falsedad contable bajo algún tipo: pues el precio anotado en la contabilidad se corresponde con el precio-de-cierre (por más que éste sea el resultado de la manipulación bursátil subyacente del agente; por ella deberá responder penalmente, pero no por la contabilidad sobrepuesta).
} 


\section{Polit. crim. Vol. 12, № 24 (Diciembre 2017), Art. 13, pp. 1106-1183. [http://www.politicacriminal.cl/Vol_12/n_24/Vol12N24A13.pdf]}

Se comprende entonces que pueda resultar difícil distinguir esta modalidad manipulativa de una transacción lícita pero que, por sus solas características objetivas-externas (contexto, volumen, precio, oportunidad) resulte igualmente idónea para determinar cambios en los precios. Lo decisivo para determinar la ilicitud de una transacción en este contexto estaría dado por la ausencia de motivaciones económicas de inversión o desinversión (y en su ocultamiento); es decir, la transacción manipulativa carecería de un motivo lucrativo distinto a aquel que coincide con la búsqueda de injerencia sobre el precio-de-mercado, injerencia desde la cual se abren posibilidades de ganancia para el agente ${ }^{81}$. De ahí que los precios resultantes hayan de considerarse artificiosos -al tenor del art. 52- en cuanto es artificiosa la motivación que guía las transacciones. Lo anterior, por cierto, sin perjuicio de la objetiva idoneidad manipulativa ex ante.

Todo lo anterior explica muy bien la colocación de las estabilizaciones en este contexto, al tenor del art. 52 y en perfecta sintonía con el derecho comparado. Como se ha explicado latamente en otro lugar ${ }^{82}$, la motivación de las estabilizaciones es per se manipulativa: con ellas no se busca invertir en el respectivo valor, sino precisamente una injerencia en su precio-de-mercado. De ahí su preliminar ilicitud (su carácter típico). Con todo, esa tentativa de injerencia puede ser valorable en un mercado primario, allí donde se busque restablecer condiciones adecuadas de precio, para no desincentivar el recurso al mercado de oferta pública de valores. Esto explica el tenor del inciso $2^{\circ}$ del artículo 52, en virtud del cual se autorizan las estabilizaciones en el mercado primario, en la medida que se ajusten a la regulación dictada por la $\mathrm{SVS}^{83}$. Del sentido de esta excepción hay también constancia en la historia de la LMV:

"existen ciertas actividades legítimas de estabilización de precios que se efectúan durante el período de colocación (underwriting) de valores. Estas estabilizaciones sólo podrán efectuarse de acuerdo a reglas generales impartidas por la Superintendencia." (Informe Técnico, Compendio Historia de la LMV, p. 43) ${ }^{84}$.

Como se ha dicho a lo largo de este trabajo, la prohibición del art. 52 se condice con las manipulaciones cuyo mecanismo de actuación es de injerencia directa.

\footnotetext{
${ }^{81}$ En este sentido, PERDUE, "Manipulation", cit. nota no 4, p. 392; cfr. también, LONDOÑO, "Ilícito de manipulación", cit. nota $n^{\circ}$ 2, p. 107. En el documento del Comité de Autorregulación de las Bolsas de Comercio y Electrónica puede leerse un postulado en esta dirección, allí donde se señala que: “(...) toda operación debe tener un contenido comercial por sí misma y no ser un instrumento para marcar precios" (Doc. Comité de Autorregulación, op. cit., apartado II.4 del documento de autorregulación).

${ }^{82}$ Cfr. LONDOÑO, "Aproximación histórico-comparada", cit. nota n ${ }^{\circ} 1$, pp. 428-432.

${ }^{83}$ Con todo, como se ha sostenido en LONDOÑO, "Aproximación histórico-comparada", cit. nota $n^{\circ} 1, \mathrm{p}$. 431, en Chile no existiría una regulación de la estabilización como la que faculta el inciso $2^{\circ}$ del art. 52 LMV, de modo que la justificación que ese inciso $2^{\circ}$ supone sería, en principio, inaplicable.

${ }^{84}$ En otro pasaje puede leerse: "Ahora bien, dentro de este Título [VIII] se han dispensado ciertos valores nuevos, o ciertos valores que no fueron objeto de oferta pública, de que se puedan transar con autorización de la Superintendencia mediante procedimientos distintos de la oferta. ¿Por qué? Porque como se trata de valores nuevos, no se sabe, no se ha semblanteado el mercado, no se conocen sus posibilidades, hay que analizar para no destruir esta sociedad que quiere captar el crédito del público y que es nueva. Igual ocurre con los valores de acciones o valores en general que no tuvieron oferta pública y que requieren, entonces, de una adecuación en un nivel transaccional privado antes de llegar a la oferta pública, que es el régimen normal." (de la Relación de Salvador Gutiérrez Asenjo, Acta N 30/81. Fecha 15 de octubre, 1981, p. 112 del Compendio BCN de la historia de la LMV).
} 
LONDOÑO, Fernando “¿Qué prohíben los artículos 52 y 53 de la Ley de Mercado

de Valores? Reconstrucción dogmática de las figuras de manipulación

de mercado en el derecho chileno".

En ese marco es preciso distinguir dos hipótesis. (1) Las manipulaciones operativas disruptivas, en las que el nuevo o potencial nivel de precio-de-mercado (artificial) se explica por el efecto directo ("mecánico") de las compras o ventas del manipulador, operaciones que, agregadas a la demanda u oferta por el título transado, aumentan la presión de una fuerza sobre otra, con la consecuente alza o baja del precio, respectivamente. Se trata de un tipo de manipulación especialmente plausible en mercados pocos profundos, respecto de títulos de baja liquidez (cfr. a título ejemplar el caso MBI, supra 1.2.1.a). (2) Las manipulaciones operativas que se sirven de un acaparamiento seguido de un abuso de posición, con imposición (constricción) de un determinado precio ${ }^{85}$, típicamente en perjuicio de los short-sellers ${ }^{86}$ en los mercados de derivados (manipulaciones como los corners o squeezes ${ }^{87}$ ).

La subsunción bajo el art. 52 del primer orden de manipulaciones operativas (las meramente disruptivas, de injerencia mecánica en el precio) no es problemática. Ellas configuran el caso central cubierto por el art. 52.

La subsunción del segundo orden de manipulaciones (por imposición o con abuso de posición) no puede descartarse a priori, para todos los supuestos, pero resulta especialmente problemática. Las dificultades de subsunción de este segundo grupo radican en dos órdenes de características de los mercados de derivados. Una estructural y que enfrenta una resistencia objetiva de tipicidad a la luz del Título VIII-59e) LMV; otra contingente y que enfrenta una dificultad más bien hermenéutica en ese mismo contexto.

La primera dificultad se explica fácilmente: en la medida que el art. 52 sólo se refiere a transacciones en valores, resulta altamente problemática la subsunción de una manipulación del precio de instrumentos derivados que opere únicamente mediante una injerencia indebida en el activo subyacente, en la medida que éste no constituya a su vez un título-valor en los términos de la LMV (como por ejemplo el caso de derivados cuyo activo subyacente sea una moneda o una tasa). Así, de quien para manipular el mercado de Futuros Dólar ${ }^{88}$ manipula el tipo de cambio, no puede decirse que realiza una conducta prohibida por el art. 52 LMV: en efecto, si bien se busca allí "hacer variar artificialmente los precios" de valores (títulos derivados), no se hace "efectuando transacciones en

\footnotetext{
${ }^{85}$ De interés, cfr. Cfr. MATUS, Jean Pierre, "De nuevo sobre la falta de punibilidad de los atentados contra la libre competencia, de conformidad con el Art. 285 del Código penal. Algunos aspectos de la discusión con Héctor Hernández en Política Criminal”, Política Criminal Vol. 8, No 15 (Julio 2013), Doc. 1, pp. 314-362, disponible en: http://www.politicacriminal.cl/Vol 08/n_15/Vol8N15D1.pdf, p. 340, quien aunque argumentando desde una óptica muy distinta y sin tomar posición directa sobre el contenido del Título VIII más allá del establecimiento de su relación (concursal) de subsidiariedad táctica con el art. $285 \mathrm{CP}$, admite la posibilidad de una alteración mediante coacción como hipótesis subsumible bajo el art. 52 LMV.

${ }^{86}$ Quienes venden-en-corto, especulando a la futura baja del precio-de-mercado, con la consecuente ganancia asociada a la diferencia favorable entre el precio de venta-en-corto y el precio-de-mercado para la compra ulterior.

${ }^{87}$ Una explicación muy sintética de estas formas de manipulación en mercados de derivados ofrece ahora MARKHAM, Jerry W., Law Enforcement and the History of Financial Market Manipulation, New York: Routledge, 2015, p. 3, identificando corners y squeezes con formas de acaparamiento-control total o mayoritario, respectivamente.

${ }^{88} \mathrm{Cfr}$. http://www.bolsadesantiago.com/mercado/Paginas/Derivados.aspx
} 


\section{Polít. crim. Vol. 12, No 24 (Diciembre 2017), Art. 13, pp. 1106-1183. [http://www.politicacriminal.cl/Vol_12/n_24/Vol12N24A13.pdf]}

valores". Dicho en otros términos: dado que la manipulación vía mercado subyacente supone una injerencia indirecta, la subsunción bajo el art. 52 no resulta a la mano ${ }^{89}$.

La segunda dificultad de subsunción bajo el art. 52 es, como se ha anticipado, contingente y descansa en un presupuesto hermenéutico general para la lectura del Título VIII. Esta dificultad depende de la concreta configuración del mercado de derivados, particularmente del grado de transparencia y densidad de su mecanismo de formación de precios. Conforme a una clave de lectura sobre la que se volverá más abajo (cfr. infra 2.4.1.d) la afectación de un interés propiamente institucional o supra-individual -como el que se considera en juego en el Título VIII- puede emerger sólo allí donde los precios-de-mercado sean reconocidos precisamente como tales: como el resultado de instancias de formación que satisfagan exigencias elementales de publicidad, apertura y densidad transaccional, lo que se encuentra en relación con el grado de formalidad y densidad normativa del sistema, principalmente por lo que se refiere a los deberes de transparencia (régimen de revelación obligatoria). Si un determinado estándar no se alcanza (de modo que el precio manipulado no pueda contar como precio-de-mercado), habrá que entender que la conducta redunda en la sola afectación de intereses patrimoniales, ciertamente merecedores de protección penal (a título de fraude común, eventualmente), pero no con cargo a un tipo penal configurado sobre el eje de la LMV.

Bajo esa premisa hermenéutica tocaría entonces preguntarse por la situación de los mercados de derivados en Chile (OTC y bursátil) ${ }^{90}$ y sus mecanismos de formación de

\footnotetext{
${ }^{89} \mathrm{Si}$ acaso puede pretenderse su subsunción bajo el inciso $2^{\circ}$ del art. 53, entendiendo que la manipulación del mercado subyacente se deja leer como inducción a la compra o venta de los respectivos títulos derivados, es algo discutible, cuya solución parece depender en parte de la concreta modalidad ejecutiva y en parte del sentido que deba darse a la fórmula "acto, práctica, mecanismo o artificio (...) fraudulento." Sobre esto se volverá luego. En fin, la manipulación de ciertos bienes subyacentes podría todavía caber en el tipo de común de alteración de precios del art. $285 \mathrm{CP}$, amén de eventuales infracciones a la regulación bancaria, tratándose de divisas.

${ }^{90}$ En Chile coexisten actualmente dos modelos de negociación de derivados, como por lo demás es común en el resto del mundo. La forma tradicional de transacción de derivados en Chile - y que posibilita todavía hoy el grueso de las negociaciones en derivados - es de tipo extra-bursátil u OTC ("Over-The-Counter" = "fuera de rueda" o "fuera de bolsa"). Consiste en negociaciones bilaterales directas (no abiertas) que mayormente interesan a entidades bancarias, inversionistas institucionales y compañías de seguros, facilitadas por intermediarios hacedores de mercado (market makers). La información sobre los precios es fragmentaria, no disponible de modo agregado y abierto al público. Al respecto, cfr. BUDNEVICH, Carlos y ZURITA, Salvador, "Diagnóstico, Evaluación y Propuesta de Desarrollo del Mercado de Derivados en Chile", febrero de 2010, pp. 64 ss., especialmente pp. 71-72 y 84, disponible en http://www.svs.cl/portal/publicaciones/610/w3-article-15011.html. El mercado bursátil de derivados, por otra parte, es reciente: se encuentra operativo desde fines de 2015 y no ha alcanzado todavía altos niveles de profundidad (como se ha dicho, el modelo OTC sigue constituyendo la vía de negociación más común de derivados). En el mercado bursátil de derivados las transacciones se realizan a través de la plataforma electrónica de la Bolsa de Comercio - la misma utilizada para las operaciones en acciones e instrumentos de renta fija - y tanto las ofertas como los precios son difundidos e informados abiertamente (cfr. el Reglamento General de Futuros aprobado por resolución exenta N. 82 de la SVS, apartados 2.5 y 3, disponible en: http://www.bolsadesantiago.com/Biblioteca\%20de\%20Archivos/Extension/Documentos/20150409\%20Regla mento\%20General\%20de\%2010s\%20Mercados\%20de\%20Futuros_APROBADO\%20SVS.pdf.). En fin, el mercado bursátil de derivados opera en base a un sistema de liquidación concentrado en una contraparte central (actualmente la ComDer) y cuenta también con hacedores de mercados para favorecer la liquidez del sistema. El autor agradece en este punto a Gustavo Alarcón González, representante de un market maker del
} 
LONDOÑO, Fernando “¿Qué prohíben los artículos 52 y 53 de la Ley de Mercado

de Valores? Reconstrucción dogmática de las figuras de manipulación

de mercado en el derecho chileno".

precios. Una respuesta detallada y segura supondría valorar la situación fáctica de aquellos mercados $^{91}$, lo que -por tratarse de una cuestión prevalentemente empírica- desbordaría los propósitos y posibilidades de este trabajo. Con todo, al menos las dimensiones de transparencia y publicidad (que no la dimensión de profundidad o densidad transaccional) son permeables a una valoración normativa, "desde afuera" (aunque por cierto parcial: "on the books"). En este plano no es aventurado afirmar que la inserción de las transacciones de derivados en un sistema bursátil -como el que ofrece en Chile la Bolsa de Comercio, bajo exigencias de transparencia comparables a las que rigen para los títulos no-derivadosofrece condiciones compatibles con un modelo regulado-formal de precios-de-mercado. Una respuesta menos segura merecería el caso del mercado OTC de derivados en Chile ${ }^{92}$.

\subsubsection{Art. 53 LMV}

$\mathrm{Si}$ - como se ha dicho - el art. 52 LMV cubre formas de manipulación de injerencia directa en el mercado de valores, el art. 53 LMV permitiría comprender el otro gran flanco de las manipulaciones: aquellas cuyo mecanismo de actuación pasa en especial por el ejercicio de alguna forma de injerencia en los presupuestos cognitivos en base a los cuales los participantes toman decisiones de inversión o desinversión. Dicho en palabras más sencillas: aquellas que se valen de alguna forma de engaño o de inducción a error.

De ahí entonces que pueda describírseles como manipulaciones connotadas de mecanismos de injerencia indirecta en los precios; indirecta en cuanto la alteración del precio pasa por la modificación del comportamiento de un número indeterminado de inversionistas, quienes operando (bajo engaño) sobre la oferta o la demanda, conducen el precio hacia el nivel de precio esperado por el agente manipulador.

mercado bursátil de derivados, por sus atentas respuestas a una entrevista semi-estructurada diseñada por el suscrito.

${ }^{91}$ Para un diagnóstico sobre la situación del mercado chileno de derivados hasta 2010 (hasta entonces representativa de un mercado OTC de derivados), cfr. BUDNEVICH/ZURITA, "Diagnóstico", cit. nota n 90, pp. 64 y ss.

${ }_{92}$ Considérese lo dicho supra en la nota $\mathrm{n}^{\circ}$ 90. Contra lo que podría pensarse, el mercado chileno OTC de derivados está dotado de un importante nivel de regulación, con múltiples entes reguladores competentes (cfr. BUDNEVICH/ZURITA, "Diagnóstico", cit. nota n 90, pp. 73 y ss.); con todo, se trata de una regulación más bien atingente a los actores del mercado (inversionistas e intermediarios), que no necesariamente encuentra un correlato en la regulación y en la transparencia del mecanismo de formación de los precios; en efecto, los precios tienden a permanecer encapsulados en la lógica de las negociaciones bilaterales, sin que aparezcan agregados e informados abiertamente al público, de modo que difícilmente puede darse por suficiente una expectativa de fiabilidad de los precios. Que no exista una plataforma integrada de negociación es decisivo en este contexto. Con lo anterior de ningún modo se pretende sugerir que un modelo OTC de negociación sea en sí mismo incompatible con la tutela penal en sede de manipulación o abusos de mercado de valores. Por lo demás, que en la especie pueden observarse expectativas de transparencia altamente diferenciadas lo demuestra la existencia de distintos tipos de OTC en otros mercados del mundo, desde aquellos que derechamente compiten en transparencia con los mercados bursátiles, hasta aquellos que - como los "Pink Sheets" - incluyen en sus listados títulos de sociedades derechamente opacas (= "penny stocks"); al respecto, para el mercado de los EE.UU., una breve noticia puede apreciarse en: KLEIN, William A.; COFFEE Jr., John C. y PARTNOY, Frank,, Business Organization and Finance. Legal and Economic Principles, New York: Foundation Press, 11th. ed., 2010, pp. 425-427. 


\section{Polít. crim. Vol. 12, No 24 (Diciembre 2017), Art. 13, pp. 1106-1183. [http://www.politicacriminal.cl/Vol_12/n_24/Vol12N24A13.pdf]}

\subsection{Segundo planteamiento base: sobre la unidad de propósito y la relación (de especialidad) entre el inc. $1^{\circ}$ y $2^{\circ}$ del art. $53 \mathrm{LMV}$. El alcance del inc. $1^{\circ}$ del art. 53}

Desde esta óptica se comprende el sentido de las transacciones y cotizaciones ficticias de que trata el inciso $1^{\circ}$ del art. 53: ambas modalidades son especialmente idóneas para trasmitir señales falsas al mercado; ya porque se trata de transacciones carentes de consecuencias económicas o no representativas de una real interacción transaccional (transacciones aparentes); ya porque se trata de precios registrados o publicados (cotizaciones) que no reflejan el resultado de las transacciones realmente verificadas en el mercado ${ }^{93}$. Así, tanto las transacciones (ficticias) como las cotizaciones (ficticias) transmiten información al mercado: le dan señales a los inversionistas sobre las condiciones del mercado de un determinado título, ya condicionándolos a comprar o a no vender (si las transacciones y precios ficticios representan "señales auspiciosas" sobre el título), ya condicionándolos a vender o a no comprar (si las transacciones y precios ficticios representan "señales pesimistas" sobre el título). Se comprende que estas decisiones de inversión o desinversión -agrupadas bajo las fuerzas de la demanda y la oferta- mueven los precios en el sentido buscado por el agente manipulador: hacia el alza si mediante las transacciones o cotizaciones ficticias aquel ha buscado transmitir señales (falsamente) optimistas al mercado; hacia la baja en cambio si con dichas maniobras se han transmitido señales (falsamente) pesimistas al mercado.

Al tenor del inc. $1^{\circ}$ del art. 53, la prohibición alcanza también a aquellas transacciones ficticias efectuadas a través de negociaciones privadas. La LMV define ese carácter en términos puramente negativos, entendiéndose que no han de reputarse privadas "todas aquellas transacciones de valores que tengan su origen en ofertas públicas de los mismos o que se efectúen con intermediación por parte de corredores o agentes de valores" (art. $1^{\circ}$ inc. $1^{\circ}$ ). Por su parte, el inc. $2^{\circ}$ del art. $1^{\circ}$ dispone que la transacciones privadas quedan excluidas de la regulación contenida en la LMV, salvo excepcionalmente, "en los casos en que ésta se remita expresamente a ellas". Pues bien, éste es un supuesto de aquellos, y su inclusión puede hacer sentido desde un punto de vista funcional: se explica desde que el conocimiento público de las transacciones privadas puede también tener un efecto condicionante de la percepción del mercado, respecto de los valores regidos por la $\mathrm{LMV}^{94}$. Considérese que el agente manipulador querrá justamente favorecer ese conocimiento, en cuanto imprescindible para la concreción de su tentativa de injerencia en el precio-demercado.

Bajo este inciso resultan subsumibles tipologías clásicas de manipulación, ampliamente conocidas por la casuística. Su caracterización positiva comparada data ya de la legislación federal estadounidense de los años '30 del siglo pasado; así, a este inciso han de

\footnotetext{
${ }^{93}$ Es importante hacer presente que el patrón común de actuación de las transacciones ficticias supone una injerencia indirecta sobre los precios, pero pueden también incidir directamente en los precios, al menos en la medida que se realicen en volúmenes y a precios tales que condicionen directamente los precio-de-mercado del día bursátil en cuestión.

${ }^{94}$ En la medida que se trate de valores para los cuales exista un mercado suficientemente regulado (en sede de transparencia informativa), en los términos que se discutió supra 2.2.1 (hacia el final, en el cuerpo asociado a las notas a pie $\mathrm{n}^{\circ}$ 90-92) y considerando lo que se discute infra 2.4.1d] a propósito de los valores no regidos por la LMV y la propuesta de interpretación que allí se ofrece.
} 
LONDOÑO, Fernando “¿Qué prohíben los artículos 52 y 53 de la Ley de Mercado de Valores? Reconstrucción dogmática de las figuras de manipulación de mercado en el derecho chileno".

reconducirse las conocidas wash sales o wash transactions (cfr. caso MBI comentado supra 1.2.1.a), las matched orders o matched transactions o la painting the tape ${ }^{95}$, en la que derechamente se falsifica el output correspondiente a la cotización de los valores.

Nótese que el sentido de la caracterización del inciso $1^{\circ}$ del art. 53 es coincidente con la del inc. $2^{\circ}$; en efecto, ambas prohibiciones apuntan a dar cobertura a las tipologías de manipulación que actúan mediante injerencia indirecta, específicamente por la vía del recurso a alguna forma de engaño. En ese contexto, el contenido del inc. $1^{\circ}$ aparece como especial respecto al del inc. $2^{\circ}$, de tal modo que su cobertura está de todos modos asegurada por la amplia fórmula del inc. $2^{\circ}$. Con todo, la inclusión de una prohibición específicamente alusiva a transacciones y cotizaciones ficticias hace sentido -más allá de la redundanciapara potenciar el rendimiento caracterizador del tipo, desde que, como se ha dicho, esas maniobras representan casos centrales -ineludibles y muy extendidos- de manipulación bursátil. Lo anterior no obsta por cierto a que la caracterización pueda haber sido más segura, explicitando el sentido manipulativo de las transacciones y cotizaciones ficticias (un sentido que aquí se ha reconocido como sustrato implícito del tipo, a modo de antijuridicidad material, sobre la base de una reconstrucción histórico-sistemática).

Como se ha dicho en otro lugar ${ }^{96}$, una explícita connotación manipulativa (como la que existe en la ya comentada §9[a][1] SEA'34) pudo parecerle innecesaria a nuestra LMV quizás por parecerle intrínseca una idoneidad engañadora como cualidad del carácter ficticio de las conductas- pero su falta es lamentable, en cuanto su literalidad concede algo de espacio a interpretaciones (textualistas) que contrarían el sentido de protección y la sistemática del título VIII LMV. Antes que nada existe el riesgo de dar espacio a interpretaciones "patrimonialistas", en clave individual. Así, por ejemplo, quien pretenda ver en esta disposición la prohibición (y punibilidad con pena de crimen vía 59 e]) de una hipótesis no especialmente diversa al mero contrato simulado patrimonialmente perjudicial, como por ejemplo el que castiga nuestro Código Penal en el art. $471 \mathrm{~N}^{\circ} 2$ o bien una hipótesis de engaño instrumental a una estafa común.

Piénsese por ejemplo en quien simule una transacción para aparentar desprenderse de un paquete accionario, con el sólo propósito de rebajar sus obligaciones en sede de alimentos del derecho de familia. Una conducta semejante es claramente típica y punible en sede de Ley de Familia (o bien del propio $471 \mathrm{~N}^{\circ} 2 \mathrm{CP}$ ), pero ciertamente no puede contar como manipulativa del mercado de valores, al menos no en la medida que la transacción en sí misma no tenga la idoneidad para llevar a error al mercado (por ejemplo porque insignificante en el universo de transacciones).

Puede también pensarse en el caso de transacciones ficticias realizadas por el agente de un corredor con el propósito de generar mayores comisiones por concepto de intermediación (contra el cliente y/o contra el empleador, en su caso). Aquí la conducta podría configurar en principio una hipótesis de estafa común en perjuicio del cliente y/o del empleador (desde que pueda considerarse engañosa la solicitud de pago de comisiones basada en un

\footnotetext{
${ }^{95}$ Para todas las tipologías anteriores, cfr. LONDOÑO, "Ilícito de manipulación”, cit. nota no 2, pp. 86 y ss.

${ }^{96}$ Cfr. LONDOÑO, “Aproximación histórico-comparada”, cit. nota n 1, pp. 426-427.
} 
Polít. crim. Vol. 12, № 24 (Diciembre 2017), Art. 13, pp. 1106-1183.

[http://www.politicacriminal.cl/Vol_12/n_24/Vol12N24A13.pdf]

presupuesto falso), pero no podrá verse como un supuesto de manipulación bursátil, salvo que por las características y entidad de las operaciones ficticias ellas puedan reputarse idóneas para conducir a error al mercado en general (y ya no sólo al cliente o al empleador para el cobro de unas comisiones). Lo anterior, supuesto además que el tipo sea compatible con el dolo eventual (sobre lo cual cfr. infra 2.5 y 3.3.1).

En otro lugar ya se ha adelantado la inconsistencia de una reinterpretación "patrimonialistaindividual" de las prohibiciones del Título VIII LMV ${ }^{97}$. El caso del inciso $1^{\circ}$ del art. 53 ofrece un nuevo espacio para reafirmar esa posición.

En este contexto la voz "cotizaciones ficticias" presenta un formidable valor hermenéutico. En efecto, consideradas las cotizaciones como el reflejo público (publicado) de los precios de los valores transados en la bolsa ${ }^{98}$, se capta el sentido de la prohibición y cómo, a la vez, su objeto coincide con un interés supra-individual. Así, la falsificación de las cotizaciones resulta perfectamente idónea para inducir a error al mercado y, desde allí, para condicionar los precios-de-mercado reales a partir de decisiones de inversión o desinversión que descansen en dicha falsificación. Esta modalidad de manipulación es por lo demás bien conocida en la literatura ${ }^{99}$ y representa una forma radical de manipulación operativa impropia, en cuanto la falsificación no requiere ya ni aún una apariencia de transacción ejecutada, sino que se ejerce directamente sobre los reportes de precios o transacciones. Supuesta entonces la inexistencia de las transacciones, la hipótesis se condice con la tipología de las manipulaciones informativas.

\subsection{El alcance del inc. $2^{\circ}$ del art. $53 \mathrm{LMV}$}

Con esto se llega por fin al inciso $2^{\circ}$ del art. 53. En otro lugar ${ }^{100}$ se ha tenido ocasión de tomar posición sobre sus aspectos problemáticos. Aquí no resta más que sintetizar aquellas explicaciones, organizándolas de modo que den lugar a una lectura lineal de la norma.

Consta el inciso de dos variantes o modalidades de conducta alternativas. Por una parte prohíbe "efectuar transacciones (...) [sobre valores regidos o no por la LMV] por medio de cualquier acto, práctica, mecanismo o artificio engañoso o fraudulento". Por la otra prohíbe "inducir o intentar inducir a la compra o venta de valores, regidos o no por esta ley, por medio de cualquier acto, práctica, mecanismo o artificio engañoso o fraudulento".

El sentido general que cabe dar a ambas variantes es el de la prohibición de cualquier modalidad de manipulación -ya transaccional, ya informativa- en la medida que opere sobre los precios-de-mercado con recurso a mecanismos engañosos. Esto es, ambas variantes se proponen dar cobertura a formas de injerencia indirecta por vía de engaño, por oposición a la injerencia directa con recurso a un ejercicio de poder de mercado, de la que especialmente se ocupa el art. 52.

\footnotetext{
${ }^{97}$ Cfr. LONDOÑO, “Aproximación histórico-comparada”, cit. nota $\mathrm{n}^{\circ} 1$, passim.

${ }^{98}$ Ya se ha dicho que este es el inequívoco sentido que le atribuye la LMV: cfr. la letra d] de su art. 43.

${ }^{99}$ En línea con la painting de tape, ampliamente conocida en la literatura: cfr. LONDOÑo, “Aproximación histórico-comparada", cit. nota $n^{\circ} 1$, pp. 451, nota $n^{\circ} 233$.

${ }^{100}$ Cfr. LONDOÑO (2015), “Aproximación histórico-comparada”, cit. nota ${ }^{\circ} 1$, passim.
} 
LONDOÑO, Fernando “¿Qué prohíben los artículos 52 y 53 de la Ley de Mercado de Valores? Reconstrucción dogmática de las figuras de manipulación de mercado en el derecho chileno".

Difieren las variantes del inciso en comento en que mientras la primera de ellas gira en torno a una hipótesis medial concreta, consistente en transacciones connotadas de valencia engañadora $-\mathrm{y}$ por tanto idóneas para conducir a error al mercado- la segunda se concentra en el sentido funcional de la conducta; esta segunda variante es por tanto más amplia, en la medida que da cabida a cualquier conducta (acto, práctica, mecanismo o artificio) idónea para inducir a la compra o venta de valores bajo un supuesto de engaño.

Así, mientras la primera variante se dirige a las manipulaciones operativas impropias, la segunda variante completa la cobertura de las modalidades manipulativas de injerencia indirecta por vía de engaño. De este modo, quedan bajo el alero de esta segunda variante todas las formas de manipulación informativa, amén de las manipulaciones realizadas mediante acciones (hechos o eventos) ejecutadas fuera del mercado bursátil (action based manipulation).

Si se conecta la relación de estas dos variantes del inc. $2^{\circ}$ con el contenido del inc. $1^{\circ}$ del art. 53, se obtiene lo siguiente: entre ellas existiría una relación de progresiva especificidad caracterizadora de las manipulaciones de injerencia indirecta por vía de engaño. Así, una parte del contenido del inciso $1^{\circ}$ (las transacciones ficticias) representa un caso especial respecto a las transacciones engañosas a que se refiere la primera variante del inc. $2^{\circ}$. A su vez, la fórmula de la primera variante puede considerarse especial respecto a la cláusula de inducción constitutiva de la segunda variante del inc. $2^{\circ}$ del art. 52. Podría pensarse entonces que, para hacerse cargo de todas las formas de manipulación de injerencia indirecta mediante engaño, la LMV pudo haberse limitado a la sola segunda variante del inc. $2^{\circ}$. Eso es correcto y no puede sino acusarse cierta redundancia. Con todo, considerando la relativa ambigüedad de la segunda variante del inc. $2^{\circ}$ (al menos si se la toma sin consideraciones de contexto), hay que decir que el recurso a las fórmulas especiales contribuye a la caracterización de la prohibición anti-manipulativa en comento. En lo demás ya se ha explicado que la relativa redundancia se explica a partir del pasaje desde el art. 48 del proyecto de ley original de 1980 y los artículos 52 y 53 la LMV vigente (cfr. supra 1.1.).

Hasta aquí sólo se han hecho afirmaciones sintéticas sobre el alcance del inc. $2^{\circ}$ del art. 53. Toca ahora pasar revista a la norma con detalle, dando cuenta de las explicaciones de texto en línea con las afirmaciones anticipadas.

2.4.1. Primera modalidad típica del inciso $2^{\circ}$ del art. 53 LMV: efectuar transacciones [...] por medio de cualquier acto, práctica, mecanismo o artificio engañoso o fraudulento

En lo que sigue se completará la toma de posición provisional anticipada en otro lugar, a propósito del comentario a la regulación federal estadounidense que sirvió allí de objeto de comparación ${ }^{101}$.

Las transacciones prohibidas en el inc. $2^{\circ}$ del art. 53 LMV deben necesariamente estar connotadas de una valencia engañadora o fraudulenta, al tenor de la segunda parte del

${ }^{101}$ Cfr. LONDOÑO, “Aproximación histórico-comparada”, cit. nota n 1, pp. 418 y ss. 
Polít. crim. Vol. 12, № 24 (Diciembre 2017), Art. 13, pp. 1106-1183.

[http://www.politicacriminal.cl/Vol_12/n_24/Vol12N24A13.pdf]

inciso, que viene a adjetivar a las transacciones objeto de la conducta. No podría ser de otro modo, por lo demás, pues mal podría la ley prohibir las transacciones a secas, sin cualificación alguna; de lo contrario, la fisiología misma de los mercados de valores quedaría proscrita.

a) ¿"Engañoso o fraudulento"?

¿Pero qué ha de entenderse por engañoso o fraudulento en este contexto? ¿Ha de atribuírseles un contenido diferenciado o no?

A modo de introducción al problema, digamos que dos opciones interpretativas se abren en este contexto: una alternativa es asumir que la disyuntiva engaño/fraude constituye aquí un mero pleonasmo, tendencialmente estéril o bien, a lo sumo, de utilidad para añadir expresividad a la fórmula (tesis del pleonasmo); otra vía es ofrecer un sentido posible para cada adjetivo, idealmente en el marco de una interpretación consistente con la lectura antimanipulativa de la fórmula (tesis diferenciadora). Aquí se opta por el segundo camino, identificando en el adjetivo fraudulento la descripción de una forma especialmente dañina o lesiva de manipulación; es decir, fraudulento como "perjudicial"102, pero no con referencia a intereses patrimoniales-individuales, sino como lesión especial a un interés institucional o supraindividual como lo es el mecanismo de formación de los precios-de-mercado.

Pero conviene ir paso a paso.

Comencemos por decir que, si como aquí se ha defendido, se postula un sentido antimanipulativo unitario para las prohibiciones del Título VIII, entonces las transacciones prohibidas (engañosas o fraudulentas) deben tener una cualidad tal que, a partir de ellas o de sus efectos (la apariencia creada a partir de ellas), los intervinientes en el mercado puedan verse movidos a adoptar decisiones de inversión o desinversión funcionales a la variación de precio que el manipulador busca alcanzar.

Lo anterior significa que las transacciones prohibidas por el inc. $2^{\circ}$ han de tener valencia informativa, pues de otro modo serán ex ante inaptas para realizar la injerencia (indirecta) en los precios-de-mercado a que se dirige el art. 53. Que esa valencia informativa es coherente con la expresión engañosa parece autoevidente: justamente porque puede engañarse a los intervinientes en el mercado, es que puede concretarse -a través de ellosuna alteración en los precios. Lo engañoso coincide así con una base de abierta interacción cognitiva-desorientadora, desde la cual puede ser posible la instrumentalización (= manipulación) de un número indeterminado de sujetos intervinientes en el mercado.

¿Pero en este contexto qué aporta la voz fraudulenta, como modalidad (en principio) alternativa?

\footnotetext{
${ }^{102}$ Aunque siempre bajo un presupuesto de engaño o inducción por vías cognitivo-desorientadoras. No se nos escapa que una interpretación alternativa es todavía posible, prescindiendo por completo del presupuesto de engaño o cualquier forma de inducción o condicionamiento cognitivo-desorientador, según se dará cuenta hacia el final de este apartado.
} 
LONDOÑO, Fernando “¿Qué prohíben los artículos 52 y 53 de la Ley de Mercado de Valores? Reconstrucción dogmática de las figuras de manipulación de mercado en el derecho chileno".

Rosenblut, por ejemplo, ha defendido la asimilación de este término bajo el concepto de engaño:

“(...) las conductas de inducción o manipulación deben efectuarse por medio de cualquier acto, práctica o mecanismo o artificio, que tenga el carácter de engañoso o fraudulento, concepto este último que no debe entenderse referido a la exigencia de perjuicio, sino que a una situación en que, como en muchas otras a través de nuestra legislación penal, la ley asimila la voz fraudulento a 'engañoso'." (Rosenblut, cit. nota $\mathrm{n}^{\circ} 32$, p. 188)

Es decir, el adjetivo fraudulento se disuelve en el adjetivo engañoso: un pleonasmo. El mérito de la tesis del pleonasmo se halla por de pronto en su coincidencia con la solución válida para la lengua común; en efecto, el diccionario de la RAE define fraudulento como "engañoso, falaz", 103 .

Si para dilucidar el problema se quiere en cambio atender al patrimonio semántico-técnico, propio de nuestro legislador penal, los resultados pueden ser más bien desalentadores. Aunque a veces los términos aparecen nominalmente diferenciados (como cuando en el párrafo 7 del Título IX del CP se alude a "defraudaciones" en contraste a las "estafas y otros engaños" del párrafo 8 del mismo Título), la diferenciación no es consistente o segura (por de pronto desde que en el propio párrafo 8 se asocian a los "otros engaños" figuras de defraudación que no se valen del engaño para generar perjuicios patrimoniales). De cualquier modo es dudoso que pueda atribuirse una intención semántica unívoca a una ley sectorial-mercantil como la LMV, en circunstancias que el propio legislador penal parece no tener claridad semántica al respecto.

En efecto, es ampliamente reconocido por la doctrina que la voz fraude o fraudulento se asocia en el Código Penal a realidades tan distintas como engaño (arts. 12 N.5, 274, 470 N.7 CP), perjuicio (arts. 467, 470 N.4 CP), deslealtad o abuso de confianza (466 o 284 $\mathrm{CP}$ ), ilicitud y aún amenaza (art. $287 \mathrm{CP})^{104}$. Basta quizás con una lectura al párrafo 7 del Título VI CP (arts. 284 - 287) para advertirlo, como por lo demás lo demuestra la intensa discusión que se ha suscitado de reciente a propósito del concepto de medios fraudulentos en el delito de alteración de precios del art. 285 (con motivo del caso "Farmacias") ${ }^{105}$.

\footnotetext{
${ }^{103}$ Por otra parte la tesis del pleonasmo parece sintonizar con la asunción de un relativo influjo del derecho federal estadounidense en la construcción del Título VIII LMV, en la medida que allá se emplea la voz defraud (la letra [a] de la Regla 10b-5) o bien aparecen las voces deceit y fraud usadas alternativamente (como en la letra [c] de la Regla 10b-5). Como quiera que sea, también en el contexto estadounidense las voces se confunden y son usadas de manera inconsistente por el legislador, en general, más allá de la securities market regulation (cfr. GREEN, Stuart P., Lying, Cheating, and Stealing, Oxford: Oxford University Press, 2006, pp. 148 y ss.). El punto merece sin embargo una atención más detallada.

${ }^{104}$ Cfr. MERA, Jorge, Fraude civil y penal. El delito de entrega fraudulenta, Santiago: Conosur, $2^{\text {a }}$ Ed., 1994. Igualmente considérese ETCHEBERRY, Derecho Penal, cit. nota no 60, t.III, pp. 377 y ss. y 390 ss. y GARRIDO M., Mario, Derecho Penal. Parte Especial, T. IV, $2^{\text {a }}$ Ed., Santiago: Ed. Jurídica de Chile, 2000, pp. 315 y ss.

${ }^{05}$ En ese contexto, considérense HERNANDEZ, Héctor, "La punibilidad de la colusión (secreta) de precios en el derecho chileno", Política Criminal, Vol. 7, N 13 (2012), pp. 147-167; MATUS, Jean Pierre, "Acerca de la actual falta de punibilidad en Chile de los acuerdos de precios", Política Criminal, Vol. 7, $\mathrm{N}^{\circ} 14$
} 
Polít. crim. Vol. 12, № 24 (Diciembre 2017), Art. 13, pp. 1106-1183.

[http://www.politicacriminal.cl/Vol_12/n_24/Vol12N24A13.pdf]

Tampoco el Código Civil parece estar en condiciones de ofrecer certeza en esta oscura materia $^{106}$.

Así las cosas, advierto las siguientes alternativas interpretativas: en primera lugar, la alternativa propuesta por Rosenblut, asimiladora de la voz "fraudulento" bajo el concepto de engaño (tesis del pleonasmo). Este parece un camino fácilmente transitable, sobre todo considerando que de todos modos -cualquiera sea el concepto de fraude que aquí se esgrima (aún si se le otorgara el alcance de perjudicial)- las transacciones objeto de la conducta habrán de tener esa ineludible valencia informativa; a saber, aquella que instaura una interacción cognitiva desorientadora. Esa valencia sólo puede ser compatible con la idea de engaño. Lo engañoso y lo fraudulento apuntarían en un mismo sentido, de acuerdo a esta interpretación.

Una segunda alternativa (tesis diferenciadora) supondría tomarse en serio el carácter disyuntivo de las voces en comento y entender que fraudulento significa algo distinto a engañoso. Qué pueda significar en ese contexto, no es de fácil respuesta. No es para nada obvio que deba echarse mano a conceptos del derecho penal patrimonial clásico para dar sentido a términos caracterizadores de una conducta lesiva para intereses supraindividuales, empleados además por una ley tendencialmente ajena a la óptica del derecho penal. Por de pronto, incluso si "fraudulento" significase aquí algo como "patrimonialmente perjudicial", la conducta prohibida por el art. 53 deberá tener la valencia informativa de que diéramos cuenta recién, de modo que se pueda activar el mecanismo cognitivo-desorientador ${ }^{107}$ propio de una manipulación bursátil por injerencia indirecta en los precios-de-mercado.

Ahora bien, arrancando desde una distinción analítica en el plano de la lesividad manipulativa, a la que se dedicó otro trabajo ${ }^{108}$, podría todavía hallarse un posible sentido para el uso disyuntivo de las voces en comento. Así, la voz fraudulenta, entendida como un resultado económicamente desventajoso para el mercado en su conjunto, daría cuenta de una manipulación especial, en el sentido de distorsionadora del más plausible valor de inversión del instrumento financiero de que se trate. Lo anterior, en disyuntiva a lo manipulativo en sentido general, representativo de un mero control (no necesariamente distorsionador) operativo en virtud de la instrumentalización que el engaño supone. En el primer orden se colocarían prácticamente todas las manipulaciones concebibles en este

(Diciembre 2012), Art. 3, pp. 318 - 356 (tesis luego reiterada en MATUS, "De nuevo sobre", cit. nota no 85); y SALAZAR, Andrés, "La alteración de precios como fraude. Comentarios acerca del origen histórico del artículo 285 del Código Penal chileno y su interpretación". Polít. crim. Vol. 11, № 22 (Diciembre 2016), Art. 3, pp. 391-438, disponible en: http://www.politicacriminal.cl/Vol_11/n_22/Vol11N22A3.pdf.

${ }^{106}$ Cfr. el sentido no unívoco en disposiciones como el arts. 2317 (en curiosa disyuntiva al dolo), 1578.3 (como perjuicio, en principio), 706 (en sintonía con la idea de ilegitimidad), 533 (en principio en línea con la idea de deslealtad perjudicial), 497.12 (¿como sinónimo de dolo?) y en muchas otras con un sentido amplio, representativo de alguna forma de ilícito o injusto (arts. 11 y 803, entre otros).

${ }^{107} \mathrm{Al}$ reafirmar la idea de inducción o injerencia desorientadora (engañosa) se opta por descartar una sugerente interpretación alternativa de la voz "fraudulento" en este contexto. Me refiero a la posibilidad de entender que fraudulento significa aquí "delictivo" o "ilícito": cfr. explicación infra, hacia el final de este apartado.

${ }^{108}$ LONDOÑO, "Ilícito de manipulación”, cit. nota no 2, pp. 100 y ss. 
LONDOÑO, Fernando “¿Qué prohíben los artículos 52 y 53 de la Ley de Mercado

de Valores? Reconstrucción dogmática de las figuras de manipulación

de mercado en el derecho chileno".

contexto (que actúan por engaño, pero que además distorsionan la inteligencia del mercado), mientras que en el segundo aquellas en las que se recurra a alguna forma de engaño dirigida a la alteración del precio-de-mercado, aún cuando esa alteración no necesariamente lo aleje del más plausible valor de inversión de los instrumentos en cuestión $^{109}$.

Así se tiene que serán consideradas engañosas o fraudulentas en los términos del art. 53 inc. $2^{\circ}$ aquellas transacciones que, por sus características, aparezcan idóneas para distorsionar la realidad del mercado o de los precios-de-mercado, de modo que, en virtud de su consideración, pudieren conducir (inducir) a los intervinientes en el mercado a adoptar decisiones de inversión contradictorias con la mejor información disponible al tiempo de los hechos (manipulación especial = transacciones fraudulentas), o bien, a lo menos, en línea con el tipo de incidencia que el manipulador se ha propuesto conseguir para los precios-de-mercado del título respectivo (manipulación general = transacciones engañosas). En este segundo caso, serán transacciones engañosas (que no necesariamente fraudulentas), aquellas que tengan la capacidad para incidir en los precios en el sentido buscado por el manipulador, aunque no por sí mismas (que para ese evento basta con el tipo o prohibición de estabilización o variación de los precios del art. 52), sino en cuanto inciden en la apreciación de terceros en el mercado, quienes a su turno realizan transacciones que repercuten en los precios en el sentido buscado por el manipulador. Estos terceros son así, precisamente, manipulados $^{110}$.

Lo que se propone entonces es una relación de género/especie entre las voces en cuestión. Lo fraudulento ha de compartir las propiedades del engaño, en cuanto éste es ineludible, esencial para la configuración de estas tipologías de manipulación por injerencia indirecta. Así, toda transacción subsumible en el inciso segundo ha de poder contar como transacción engañosa. Ahora bien, la transacción fraudulenta va un paso más allá, en cuanto no se limita a afectar la libre formación de los precios-de-mercado (como toda forma de control), sino que además los distorsiona en el sentido de hacerlos contradictorios con la información (veraz) disponible entonces (alejándolos del más plausible valor de inversión).

La ventaja de esta interpretación es que no disuelve, sino que da un sentido posible al uso disyuntivo de las voces en comento, a la vez que reconstruye la idea de lo fraudulento para un contexto de tutela de intereses supra-individuales o institucionales, como es el que ocupa al Título VIII LMV. Por otra parte, y al menos por lo que toca a la sede penal, esta interpretación tiene la ventaja de ofrecer un criterio para una determinación diferenciada de la magnitud de la pena (bajo el art. $69 \mathrm{CP}$, se entiende) ${ }^{111}$. El daño civil -individual-

\footnotetext{
${ }^{109} \mathrm{Si}$ el scalping ha de considerarse una forma de manipulación - y no un caso de uso de información privilegiada - sería imaginable su subsunción en este contexto (aunque bajo la segunda variante del inc. $2^{\circ}$ : inducción a comprar o vender), al menos para aquellos casos en los que la recomendación, por más que bajo un conflicto de interés no revelado, aparezca en línea con el valor de inversión del instrumento.

${ }^{110}$ Nótese que con ello se está diciendo también que el "efectuar transacciones" es el medio manipulativo y no el fin del engaño; no se trata pues de un engaño para contratar o en el contrato, sino de transacciones ejecutadas por el manipulador para con ellas engañar al mercado sobre el valor del instrumento en cuestión.

${ }^{111}$ Quizás si contra esta interpretación pueda sostenerse que ella disloca la función de los adjetivos en el plano de la causalidad manipulativa. Así, mientras la idea de transacción engañosa se condice con el rol causal o
} 
Polít. crim. Vol. 12, № 24 (Diciembre 2017), Art. 13, pp. 1106-1183.

[http://www.politicacriminal.cl/Vol_12/n_24/Vol12N24A13.pdf]

perseguible al tenor del art. 55 LMV se ubica por cierto en otro plano y deberá determinarse con prescindencia de estos conceptos, pero puede asumirse que un daño individual tenderá a aparecer siempre que estemos ante una manipulación especial (distorsión).

En suma: la adjetivización alternativa puede reconducirse a dos formas de lesividad manipulativa, general y especial, respectivamente, siempre con referencia al sistema de formación de los precios-de-mercado. Esto significa que se prohíbe no sólo aquella manipulación (fraudulenta) que aleja los precios-de-mercado del razonable valor de inversión (manipulación especial o distorsión), sino también aquella manipulación (engañosa) que simplemente condiciona la libre formación de los precios-de-mercado (manipulación general o mero control sobre los precios).

\section{Excurso: sobre la situación de la injerencia por vías de hecho genéricamente ilícitas o delictivas (no engañosas)}

En fin, parece oportuno poner en evidencia que con la lectura arriba ofrecida (que insiste en la exigencia de engaño como presupuesto ineludible, base para una inducción-a-transar de tipo desorientadora) se opta por descartar una muy sugerente interpretación alternativa para la voz fraudulento del art. 53. Concretamente, una lectura que por fraudulento entienda cualquier otra modalidad ilícita o delictiva idónea para incidir en el comportamiento de los inversionistas (para inducir a las compras o ventas en el sentido esperado por el manipulador), como paradigmáticamente el recurso a la violencia física o a la coacción ${ }^{112}$ (como injerencia por vías de hecho genéricamente ilícitas o delictivas podríamos denominar a esta clase de conducta). Una interpretación semejante permitiría comprender bajo el art. 53 casos en los que se ejecuten conductas genéricamente delictivas (o ilícitas) fuera de bolsa, en el "mundo real"- con el propósito de afectar el precio-de-mercado de un determinado valor: como por ejemplo supuestos en los que se ejecute un acto de sabotaje o atentado violento a un proceso productivo, activo económico o agente relevante del emisor, con miras a condicionar a la baja el precio-de-mercado del respectivo título. Esta interpretación alternativa permitiría dar cobertura a casos poco frecuentes, pero no inimaginables (como el escalofriante caso del atentado al Borussia Dortmund ${ }^{113}$ ). Pero la

medial del adjetivo, la idea de transacción fraudulenta no se comprende tan claramente desde ese punto de vista. Ella aludiría a una transacción que introduce distorsión, como pasaje sucesivo a la injerencia manipulativa. En fin, en perspectiva "originalista", no parece haber base alguna para sostener que la LMV pudo haber tenido en cuenta esta distinción (por más que la distinción entre manipulación general y manipulación especial pueda hallarse implícita en el debate doctrinario de la primea mitad del siglo pasado en los EEUU: cfr. LONDOÑO, "Ilícito de manipulación”, cit. nota nº 2, pp. 101-103).

112 En esta línea puede apreciarse la recepción española de la primera hipótesis de manipulación noinformativa (numeral $1^{\circ} \mathrm{del}$ art. $284 \mathrm{CP}$ ), bajo la horma del tradicional - decimonónico - tipo de alteración de precios, más que sobre el molde de las modernas figuras de manipulación del mercado de valores (de cuño europeo o estadounidense).

${ }^{113}$ Considérese en efecto el caso del reciente atentado con bomba al plantel del Borussia Dortmund, club de fútbol profesional que, como sociedad anónima, cotiza en bolsa en Alemania. El atentado fue ejecutado el 11 de abril de 2017 (el día del partido de ida de los cuartos de final de la UEFA Champions League, a disputarse contra el $A S$ Monaco) por un sujeto que en momentos previos al ataque habría adquirido put options sobre acciones del Borussia, especulando a la sucesiva caída del precio-de-mercado de la acción: cfr. la noticia en dos medios diversamente especializados: https://www.bloomberg.com/news/articles/2017-04-21/german- 
LONDOÑO, Fernando “¿Qué prohíben los artículos 52 y 53 de la Ley de Mercado

de Valores? Reconstrucción dogmática de las figuras de manipulación

de mercado en el derecho chileno".

eficacia político-criminal -en términos de ampliación de la cobertura típica- no puede ser razón suficiente para suscribir una determinada interpretación, qué duda cabe. Hay en aquella lectura aspectos sistemáticos y prácticos que resultan problemáticos.

Antes que nada conviene despejar un punto: y es que la manipulación por injerencia indirecta -así como se ha definido aquí, con recurso al engaño como inducción desorientadora ${ }^{114}$ : una que ofrece razones aparentes (erradas) para invertir o desinvertirno da cobertura a esta rara hipótesis de inducción por vías de hecho. Como parece claro, en casos como éstos no puede hablarse de un supuesto de "engaño" como input manipulativo, pues las ventas (inducidas mediante el delito) se fundan en una base real, no aparente (por más que causada por el "manipulador"): es correcta la proyección de futuros menores ingresos en estos casos (piénsese en un supuesto en el que un atentado destruya completas instalaciones de producción, etc.), de modo que las ventas del título obedecen a razones "correctas", correspondientes al (nuevo) valor de inversión.

Con ello se puede ya decir algo sobre las dos índoles de razones por las que una interpretación más amplia resulta problemática en este punto: razones sistemáticas y prácticas.

En cuanto a las razones sistemáticas: si bien se ha afirmado que la relación entre engaño y manipulación tout court (como genéro) no es de la esencia ${ }^{115}$, sí parece serlo tratandose de las manipulaciones informativas (como especie), a la que las manipulaciones de hecho resultan asimilables ${ }^{116}$. Definiciones "canónicas" de manipulación apuntan en ese sentido, asociando el fenómeno al recurso a una serie de modalidades de engaño (como input) o a la artificialidad de los precios (como output) ${ }^{117}$, con lo cual parece irrenunciable un factor de no-correspondencia entre lo valorado por el inducido-manipulado y la situación real del título o del mercado ${ }^{118}$. Hay en fin una ya asentada sistematización en la literatura (con expresión en el derecho comparado de cuño europeo-comunitario) ${ }^{119}$, que contrapone

soccer-team-attacker-hoped-to-profit-from-share-slump; http://www.sport.es/es/noticias/champions/todaverdad-sobre-motivo-del-atentado-dortmund-5986949. Agradezco al estudiante de MG UDP, Felipe Berríos, por haberme alertado sobre la relevancia bursátil de la noticia.

${ }^{114}$ Junto a lo dicho en el presente trabajo, cfr. igualmente LONDOÑO, "Aproximación histórico-comparada", cit. nota $\mathrm{n}^{\circ} 1$, pp. 457 y $461-462$ especialmente.

${ }^{115}$ Cfr. LONDOÑO, “Aproximación histórico-comparada”, cit. nota $n^{\circ}$ 1, pp. 400-401, advirtiendo sobre los casos de manipulación con recurso a un abuso de posición, así como a aquellos de manipulación operativa propia, del tipo disruptivo.

${ }^{116}$ Cfr. LONDOÑO, "Ilícito de manipulación", cit. nota n 2, nota 54 y p. 105.

${ }^{117}$ Cfr. la analítica y comprensiva definición de AVGOULEAS, The Mechanics, cit. nota no 4, pp. 13-14 y 116.

${ }^{118}$ Esto puede apreciarse también en la variante decimonónica de esta figura, bajo la forma clásica de alteración de precios del derecho penal francés, que sirvió de modelo para diversos ordenamientos: cfr. el caso del art. 419 CP Francés de 1810 y su referencia a "hechos falsos": en LONDOÑO, "Aproximación histórico-comparada", cit. nota $\mathrm{n}^{\circ}$ 1, p. 406.

${ }^{119}$ Cfr. LONDOÑO, "Aproximación histórico-comparada", cit. nota $n^{\circ} 1$, pp. 397-398, con referencia al enfoque de Loss \& Seligman en su Securities Regulation y a la adopción del modelo de abuso de mercado (dual) en el derecho comunitario europeo, a partir de la DAM 2003, especialmente con referencia al considerando 12 de su Preámbulo. 
Polít. crim. Vol. 12, № 24 (Diciembre 2017), Art. 13, pp. 1106-1183.

[http://www.politicacriminal.cl/Vol_12/n_24/Vol12N24A13.pdf]

manipulación y uso de información privilegiada a la luz del contenido de la asimetría informativa explotada o abusada: por un lado el (des)conocimiento del carácter falso o incorrecto de una determinada información o situación de mercado (manipulación); por otro lado el (des)conocimiento de información correcta, valiosa para la ponderación del valor de inversión (uso de información privilegiada). Ubicar del lado de las manipulaciones hipótesis en las que el inducido a negociar con los títulos actúa sobre la base de razones ostensiblemente correctas (que se condicen con el nuevo valor de inversión, modificado por la acción del "manipulador") trastocaría la claridad de esta distinción sistemática.

Y con ello se llega a las consideraciones prácticas: la asociación de estas hipótesis con la rúbrica de manipulación bursátil tiene una potencialidad expansiva poco controlable y, por ello, altamente problemática; en efecto, cualquier conducta dolosa que perjudique el desarrollo de los negocios del emisor (y pueden imaginarse los más variados: desde un paro laboral, hasta una conducta anticompetitiva de otro emisor) podría leerse bajo el prisma de la manipulación, abriendo la pregunta sobre si acaso el paro o la práctica anticompetiva se realizaron con miras a afectar las cotizaciones bursátiles. Y por absurdo que parezca, jesa sospecha sería también válida respecto de conductas que beneficien al emisor! El paroxismo nos ha llevado hasta casi la desfiguración de lo manipulativo. La sospecha rezaría allí: ¿se ha querido acaso incidir en la cotización bursátil al -por ejemplo- decidirse una licitación a favor de un emisor? Una restricción en el tipo subjetivo -como la que aquí se defiende, por lo demás: cfr. infra 2.5- no basta en términos prácticos.

Ahora bien -y éste es un paso decisivo- no puede en rigor descartarse a priori que conductas semejantes - perjudiciales o beneficiosas para el emisor- estén guiadas por indebidas motivaciones bursátiles. El apetito económico campea en este siglo. Pero el espacio típico ha de ser otro, no la manipulación. Lo dicho dos párrafos más arriba permite advertir la respuesta: supuestos semejantes han de leerse bajo el prisma de la figura especular a la manipulación, es decir, el uso de información privilegiada ${ }^{120}$. En efecto, las hipótesis tratadas en este apartado (ya consistan en ilícitos perjudiciales para los negocios del emisor, ya en hechos beneficiosos para aquellos) han de reprocharse -bajo una legislación de mercado de valores- no en base al hecho configurador del nuevo nivel de precio (atentado, sabotaje, paro ilegal o adjudicación de licitación que sea), sino en base a las negociaciones en valores previas a aquel hecho, reprochables en cuanto ejecutadas con el conocimiento (privilegiado) de los esperables efectos del propio hecho sobre el preciode-mercado. Nótese que una negociación previa en valores será obligada para que la oportunidad de lucro pueda concretarse en este tipo de casos. En lo demás, la subsunción dependerá de si: (1) tratándose los autores de personas no vinculadas al emisor (que puede imaginarse será lo normal en este tipo de casos), los tipos permiten la punibilidad de los

\footnotetext{
${ }^{120}$ La solución comunitaria-europea iría en esta dirección, hasta donde alcanzo a ver: cfr. el art. 8.4.d) del RAM 2014, conforme al cual la prohibición de uso de información privilegiada es aplicable si el agente posee información a partir de su involucramiento en actividades delictivas (otro tanto vale para la DAM 2014, art. 3.3.d). Esta perspectiva es originaria de la primera regulación comunitaria de abusos de mercado, la ya aludida DAM 2003, art. 2.1.d), con una explicación muy clara en su preámbulo, considerando 17: "En cuanto a la información privilegiada, deben tenerse en cuenta los casos en que la fuente de la información privilegiada no sea una profesión o función, sino las actividades delictivas cuya preparación o ejecución puedan tener efectos significativos en los precios de uno o más instrumentos financieros o en la formación de los precios del mercado regulado como tal." (la cursiva es nuestra).
} 
LONDOÑO, Fernando “¿Qué prohíben los artículos 52 y 53 de la Ley de Mercado

de Valores? Reconstrucción dogmática de las figuras de manipulación

de mercado en el derecho chileno".

outsiders bajo ese título ${ }^{121}$; y (2) el resultado configurador del nuevo nivel de precio aparece como altamente probable (de otro modo difícilmente puede hablarse de información privilegiada, en el sentido de información precisa y relevante, que otorgue a su poseedor una ventaja intolerable de cara a la incertidumbre del futuro). Normalmente esto último se vinculará al grado de desarrollo del delito o ilícito constitutivo de la vía de hecho ${ }^{122}$. En lo demás, no hace falta decir que la vía de hecho (delictiva) resultará punible en conformidad a la Parte Especial (un homicidio calificado, si se ha buscado afectar las cotizaciones asesinando al "genio creador" tras el negocio del emisor; incendio, daños, etc.).

\section{b) “Efectuar transacciones": sentido general y cobertura práctica}

Nótese por otra parte que de lo dicho se desprende que la conducta consistente en "efectuar transacciones" (la primea variante aquí tratada) es el medio manipulativo y no el fin del engaño; no se trata pues de un engaño para contratar o en el contrato (o para inducir a comprar o vender), sino de transacciones ejecutadas por el manipulador para engañar con ellas al mercado sobre el valor del instrumento en cuestión. Con este efectuar transacciones la LMV describiría una conducta manipulativa y no el resultado o subproducto de una conducta inductiva (segunda variante del art. 53 inciso $\left.2^{\circ}\right)^{123}$.

Maniobras como las pump \& dump o -en sentido opuesto- trash \& cash, ampliamente reconocidas como manipulativos en la casuística del sector, parecen adecuarse a esta variante del inciso $2^{2^{124}}$. Así, quien por ejemplo realice transacciones a precios crecientes para generar con ello una ulterior burbuja alcista y luego descargar sobre el mercado sus

\footnotetext{
${ }^{121}$ La apertura del tipo penal del art. 60 g) LMV - en contraste con el tipo de sujeto especial del art. 60 e) permitiría en principio subsumir allí usos de información por outsiders, por más que la solución no sea pacífica, sobre todo a la luz de la (¿paradojicamente?) más estrecha cobertura del sancionador administrativo bajo el supuesto del art. 165 LMV: así, SALAH, María Agnes, Responsabilidad por uso de información privilegiada en el mercado de valores, Santiago: Lexis Nexis, 2004, pp. 218-219. Igualmente críticos y partidarios de una interpretación restrictiva en lo pertinente, cfr. ROSAS, Juan Ignacio, "El delito de abuso de información privilegiada en el mercado de valores: análisis crítico de la regulación contenida en la Ley $\mathrm{N}$. 18.045", Gaceta Jurídica N. 299 (2005), apartados IV y V; y PIÑA, Juan Ignacio, "Algunos problemas del delito de uso de información privilegiada", en: GONZÁLEZ ITURRIA, Marco (Ed.), Regulaciones del Mercado de Valores, Cuadernos de Extensión jurídica, No 19, Santiago: U. Andes, 2010, pp. 123-124, si bien en ambos casos problematizando el supuesto de outsider que fortuitamente accede a la información (¿una solución distinta merecería el caso del outsider que accede a la información por medios ilícitos, como por ejemplo un supuesto de espionaje?).

${ }_{122}$ Por ello un caso como el del atentado al equipo de fútbol Borussia Dortmund (cfr. supra nota $\mathrm{n}^{\circ} 113$ ) podría resultar problemático, sobre todo si se lo valora a la luz del derecho europeo del RAM 2014, art. 8.4.d), conforme al cual sólo hay uso si el agente posee información a partir de su involucramiento en actividades delictivas. La redacción se ajusta mejor a hipótesis de obtención ilegal de información, como el espionaje por ejemplo.

${ }^{123}$ Para mayores detalles puede también consultarse LONDOÑO, "Aproximación histórico-comparada", cit. nota ${ }^{\circ} 1$, pp. 414 y ss. (comparación con la §9(a)(2) SEA 1934), así como lo que se dirá a continuación a propósito de una posible duda interpretativa que plantearía el tenor del inciso $2^{\circ}$ en comento (cfr. infra 2.4.1.c).

${ }^{124}$ En la medida en que no vayan acompañadas del recurso a información falsa, caso en el cual la segunda variante parece en condiciones de comprenderlas mejor.
} 
Polít. crim. Vol. 12, № 24 (Diciembre 2017), Art. 13, pp. 1106-1183.

[http://www.politicacriminal.cl/Vol_12/n_24/Vol12N24A13.pdf]

ventas a esos mejores precios (infla y descarga = pump \& dump), ejecuta una conducta que puede caracterizarse como manipulativa por el recurso a transacciones engañosas para el mercado (rectius: transacciones fraudulentas, en rigor, si se acoge la distinción que más arriba se hiciera).

c) Una aclaración: ¿transacción inducida mediante engaño? o ¿transacción engañosa inductiva? ¿Es la primera variante del art. 53 inciso $2^{\circ}$ una fórmula subordinada al contenido de la segunda variante o más bien una fórmula con contenido propio? Sentido interno y sentido externo de la primera variante del art. 53 inciso $2^{\circ}$.

Como se ha dicho recién, aquí no se privilegia una lectura de la primera variante del art. 53 inciso $2^{\circ}$ conforme a la cual el engaño típico resulte funcional a la realización de una o más transacciones, cual si se tratase de un supuesto de engaño para contratar con valores. Conforme a esa lectura -que podemos denominar interna al sentido de la segunda varianteel art. 53 inciso $2^{\circ}$ describiría las distintas fases de un mismo iter inductivo a transar. Así, estaría prohibido el intento de inducir a transar (segunda variante, segunda voz), luego la inducción misma a transar (segunda variante, primera voz), hasta concluir con la propia transacción inducida (primera variante), siempre bajo el supuesto de que haya mediado engaño en el proceso inductivo. Esta lectura entiende así la primera variante como una transacción inducida mediante engaño (algo que por lo demás resultaría en principio comprendido por el tipo común de estafa, sin necesidad de incomodar la legislación especial de valores).

En mi opinión esa lectura de la primera variante es incorrecta, en cuanto reduce su contenido a un mero resultado o subproducto de la segunda variante, haciendo estéril su rendimiento práctico, a la vez que oscureciendo su sentido manipulativo (y posibilitando una lectura patrimonialista como la que más abajo se cuestionará: cfr. infra 2.4.2.c).

En efecto, si se entiende la primera variante como la conclusión del iter inductivo de que trata la segunda variante, entonces ¿cuál es su aporte descriptivo? Ya la tentativa de inducción está prohibida, de modo que -a fortiori- lo estará también la transacción inducida $^{125}$.

Por otra parte, más importante aún, esa lectura oscurece el sentido manipulativo que supone la primera variante, en la medida que la reduce a un mero subproducto o resultado de la inducción. Así, la primera variante queda absorbida por la segunda, carente de contenido autónomo. Queda reducida al sentido interno de la inducción. La lectura criticada no queda así en condiciones de apreciar que, más que el resultado o punto terminal de un proceso inductivo, la primera variante es en sí misma una acción, el punto de partida de un proceso inductivo (= manipulativo). Con ello se capta el sentido externo que imprime carácter al contenido de la primera variante del art. 53 inciso $2^{\circ}$.

\footnotetext{
${ }^{125}$ Podrá decirse que también es redundante la inducción misma, en cuanto ya el intento de inducción está prohibido; eso es correcto y se comparte esa observación. Con todo, ya desde un principio la inducción concretada no está condiciones de desempeñar un papel tipológicamente autónomo respecto a la inducción tentada, a diferencia de lo que ocurre con la primera variante.
} 
LONDOÑO, Fernando “¿Qué prohíben los artículos 52 y 53 de la Ley de Mercado de Valores? Reconstrucción dogmática de las figuras de manipulación de mercado en el derecho chileno".

Así, ha de entenderse que el engaño típico del art. 53 inciso $2^{\circ}$ es funcional a la realización de una manipulación; esto es, y por lo que toca a la primera variante, que a partir de transacciones engañosas (idóneas para engañar al público inversionista) se busca alterar el precio-de-mercado del respectivo valor (normalmente del objeto material de las transacciones engañosas). De este modo, la primera variante no describiría transacciones inducidas mediante engaño (lectura criticada: patrimonialista, reconducible a una estafa común), sino transacciones engañosas inductivas (=manipulativas). ${ }^{126}$

Todo lo que se ha dicho en este apartado podría sintetizarse con eficacia haciendo ver que, conforme al tenor literal del inciso $2^{\circ}$ en comento, "efectuar transacciones" (engañosas o fraudulentas) es una conducta prohibida en sí misma, y no el resultado (subordinado) de otra conducta prohibida (la tentativa de inducción de la segunda variante).

d) Objeto material: valores objeto de las transacciones. ¿Apertura hacia una figura de engaño público en la solicitud de inversión en valores?

Del tenor del inciso $2^{\circ}$ en comento debería entenderse que las transacciones han de recaer sobre valores, regidos o no por la $L M V$. Ello es sin duda así para la segunda variante del inciso. La amplitud de esta fórmula -comprensiva de valores no regidos por la $L M V$ - abre un problema interpretativo importante. En efecto, la aparente inclusión de valores que no se ofrecen públicamente y que no cotizan en Bolsa obliga a detenerse una vez más en el sentido general de la disposición en comento (en lo demás, cfr. supra 2.2.1., a propósito de la discusión sobre los mercados de derivados). El problema se abordará en este apartado, pero los argumentos y conclusiones son igualmente válidos para la captación del sentido de la segunda modalidad típica del art. 53 inciso $2^{\circ}$ LMV (infra 2.4.2).

Comencemos por afirmar que por valores regidos por la LMV han de entenderse aquellos mencionados en el inciso $1^{\circ}$ del art. $3^{\circ}$ ("cualesquiera títulos transferibles incluyendo acciones, opciones a la compra y venta de acciones, bonos, debentures, cuotas de fondos mutuos, planes de ahorro, efectos de comercio y, en general, todo título de crédito o inversión"), en el marco de una oferta pública, así como definida en el inciso $1^{\circ} \mathrm{del}$ art. $4^{\circ}$ LMV, considerando además lo dispuesto en los arts. $1^{\circ}$ y $5^{\circ}$ de la misma ley.

Ahora bien, como se ha dicho, el inc. $2^{\circ}$ en comento prohíbe no sólo las transacciones e inducciones engañosas a la compra o venta de valores regidos por la $L M V$, sino también de valores no regidos por dicha ley. ¿Por qué esa amplitud? ¿Cómo se explica que se tutelen aquí conductas de engaño en relación con valores cuyos precios no necesariamente se forman mediante mecanismos suficientemente regulados o institucionalizados (antes que

\footnotetext{
${ }^{126}$ Recuérdese aquí el notable parecido de esta fórmula con las descripciones contenidas en la regulación europea (DAM 2003, art. 1.2 b), así como en la sección 9(a)(2) de la SEA 1934 de los Estados Unidos. Todo ello conforme se expusiera ampliamente en LONDOÑO, "Aproximación histórico-comparada", cit. nota n 1 , pp. 408 ss. Por otra parte, esta lectura se ajusta a la historia de la LMV original, en la medida que mantiene el sentido autónomo que - con más claridad aún - parecía tener la primera variante del vigente inciso $2^{\circ}$ del art. 53 en el art. 48 original del proyecto de LMV.
} 
Polít. crim. Vol. 12, № 24 (Diciembre 2017), Art. 13, pp. 1106-1183.

[http://www.politicacriminal.cl/Vol_12/n_24/Vol12N24A13.pdf]

nada en términos de transparencia informativa)? ¿Qué implicancias tiene esta fórmula para la interpretación que haya de darse al inciso en comento?

Luego se ofrecerán los detalles y las conclusiones en lo pertinente, pero puede responderse lo anterior en breve, a modo de hipótesis a refutar: la extensión del objeto material puede llevar a pensar que el inciso $2^{\circ}$ del art. 53 sería una figura dirigida a la tutela del patrimonio-individual de un círculo más o menos amplio de inversionistas o potenciales inversionistas, respecto de conductas engañosas que pudieren afectarles en contextos de solicitud o propuesta de inversión en valores, ya en el mercado primario, ya en el secundario. Lo anterior significaría que en lugar de proteger la correcta formación de los precios-de-mercado de valores de oferta pública -cual figura de manipulación y con el sentido supra-individual o institucional que aquí se le ha atribuido- la prohibición habría sido concebida en sintonía con la llamada estafa de inversión de capitales ${ }^{127}$ u otras figuras de engaño en la solicitud de inversión en valores (como las falsedades de prospecto) ${ }^{128} \mathrm{o}$, con aún mayor amplitud, figuras de engaño en un contexto transaccional relativo a valores, como la Sección 10b SEA'34 y su Regla 10b-5 del derecho federal estadounidense ${ }^{129}$, comentadas latamente en otro lugar ${ }^{130}$.

¿Es correcta esa lectura del inc. $2^{\circ}$ del art. 53? Antes de ofrecer una respuesta relativamente articulada, puede anticiparse que aquella es una lectura plausible y defendible, aunque -a juicio del suscrito- no la mejor de las lecturas. Por de pronto ella debe hacer frente a los argumentos sistemáticos, históricos y de derecho comparado que aquí se han ofrecido. En fin, una lectura semejante debe estar en condiciones de hacerse cargo de las reformas sucesivas a la LMV original, principalmente aquella que en virtud de la ley $\mathrm{N}^{\mathbf{0}} 19.301$ de 1994 introdujo la figura de falsedad de la letra f) del art. 59.

Consideremos el asunto detenidamente.

Por valores no regidos por la LMV pueden entenderse dos conjuntos u órdenes de valores. En primer lugar, asumir que la fórmula se limita a aquellos de índole estatal o públicos. A ese tipo de valores se refiere específicamente el inciso $2^{\circ}$ del art. $3^{\circ} \mathrm{LMV}$, en cuanto dispone que:

"las disposiciones de la presente ley no se aplican a los valores emitidos o garantizados por el Estado, por las instituciones públicas centralizadas o descentralizadas y por el Banco Central de Chile."

${ }^{127}$ Cfr. art. 264 a StGB alemán y la explicación de TIEDEMANN, Klaus, Manual de Derecho Penal Económico. Parte General y Especial, Valencia: Tirant Lo Blanch, 2010, p. 373, num. marg. 338.

${ }^{128}$ Cfr. por ejemplo, el art. 2623 del C.C. italiano (falso in prospetto): cfr. SEMINARA, Sergio, "Falso in prospetto", en: ALESSANDRI, Alberto (a cura di), Il nuovo diritto penale delle società, Lavis: IPSOA, 2002, pp. 201 y ss. El correlato en nuestra legislación es, como se dirá a continuación, la letra f) del art. 59 LMV.

${ }_{129}$ Aunque ciertamente con las limitaciones que ya se han expuesto y que inciden en la exclusión de contenidos relativos al uso de información privilegiada: cfr. LONDOÑO, "Aproximación históricocomparada", cit. nota ${ }^{\circ} 1$, pp. 432 y ss. Nótese en todo caso que, coincidentemente, la Regla 10b-5 también tiene alcance over-the-counter, lo que precisamente se condice con el carácter de figura de fraude en contextos de transacciones con valores: cfr. LOSS et Al, Fundamentals, cit. nota n ${ }^{\circ}$ 4, Vol. 2., Cap. 10-D, pp. 1502 ss.

${ }^{130}$ Cfr. LONDOÑO, “Aproximación histórico-comparada”, cit. nota n 1, pp. 408 ss. 
LONDOÑO, Fernando “¿Qué prohíben los artículos 52 y 53 de la Ley de Mercado

de Valores? Reconstrucción dogmática de las figuras de manipulación

de mercado en el derecho chileno".

Se trata especialmente de instrumentos de deuda como los bonos soberanos o los bonos locales, al menos por lo que atañe al Estado representado por la Tesorería General de la República y el Banco Central.

Esta interpretación no es especialmente problemática, desde que la inclusión de ese orden de valores bajo la prohibición del art. 53 puede hacer sentido desde dos puntos de vista. En primer lugar, en cuanto para algunos de dichos instrumentos existen mercados regulados, en su caso por la ley que autoriza el respectivo endeudamiento, bajo el marco del D.L. $\mathrm{N}^{\circ}$ 1263 Orgánico de Administración Financiera de 1975, así como por las propias reglas del Banco Central y su Sistema de Operaciones de Mercado Abierto (SOMA) ${ }^{131}$. Por lo que toca a los bonos soberanos de deuda exterior, considérese que se distribuyen en mercados formales en el exterior, listándose en Bolsas fuera de Chile, excluyéndose en principio la aplicación de la LMV chilena. De este modo, la cuestión se plantea fundamentalmente para los bonos locales. A su respecto, concurre una segunda razón para su protección bajo este título: el evidente interés público en la correcta cotización de estos instrumentos, considerando especialmente que su mercado está compuesto por inversionistas institucionales nacionales (Bancos y AFP especialmente), de modo que por esa vía se compromete la dimensión pública del ahorro interno ${ }^{132}$.

Con todo, una interpretación aún más amplia de los valores objeto del inc. $2^{\circ}$ del art. 53 sería todavía posible. Conforme a ella, además de los valores de índole estatal recién aludidos (art. 3 inc. $2^{\circ} \mathrm{LMV}$ ), por valores no regidos por la $L M V$ se podrían entender también aquellos que no se ofrecen públicamente (que no se ofrecen para captar capital del público en general) o cuyo registro no es obligatorio, en los términos del artículo $5^{\circ}$ en relación con los artículos $1^{\circ}$ inc. $1^{\circ}$ y $4^{\circ}$ de la $\mathrm{LMV}^{133}$. En este caso se trataría de valores que se intercambian fuera de Bolsa, a través de negociaciones bilaterales o privadas (sin intermediación por corredoras o agentes de valores, de acuerdo a lo dispuesto en el art. $1^{\circ}$ inc. $1^{\circ}$ ), en mercados tendencialmente reducidos y fragmentarios, normalmente muy volátiles. Es dudoso que para estos valores exista un mecanismo abierto y transparente de formación de precios, o bien, en todo caso, un mecanismo que merezca la expectativa de confianza que en cambio descansa en un mercado regulado, cuanto menos por lo que se refiere a la dimensión de transparencia informativa ${ }^{134}$. Como quiera que sea, estos

${ }^{131}$ Cfr. el Capítulo 1.3 del Compendio de Normas Monetarias y Financieras del Banco Central.

${ }^{132}$ No se nos escapa que en los prospectos de este tipo de bonos se excluye expresamente la aplicación de la LMV, en consonancia con el propio art. $3^{\circ}$ inc. $2^{\circ}$ de esa ley, en su caso manifestando la sola aplicación de la letra d) del art. 23 LMV. Con ello la aplicabilidad del art. 53 de la LMV podría ponerse en discusión, por más que en principio deba considerarse su primacía y aplicabilidad (salvo que otra ley disponga lo contrario). Véase a título meramente ejemplar la situación del Bono de la Tesorería General de la República BTU-10, cuya emisión se autoriza en el Decreto de Emisión del Ministerio de Hacienda, núm. 38, de 16 de enero de 2014 (D.O. de 3 de abril de 2014). Véase especialmente la letra o) del art. $4^{\circ}$ del aludido Decreto, por lo que se refiere al estatuto jurídico aplicable.

${ }^{133}$ Véase además lo que dispone el art. 23 de la LMV. Ref. especial a art. $4^{\circ}$ que permite exceptuar del régimen de inscripción la oferta de valores que no califiquen como propiamente "públicas".

${ }^{134}$ Cfr. TIEDEMANN, Manual, cit. nota $\mathrm{n}^{\circ} 127$, p. 380, contrastando la situación de los mercados regulados con la de los denominados mercados negros de capitales. Como se indicará más abajo (cfr. nota ${ }^{\circ} 138$ ), a partir de la Directiva 2004/39/CE: MiFID I, la Directiva 2014/65/UE: MiFID II y el Reglamento EU 600/2014: MiFIR, la regulación de la Unión Europea ha de algún modo forzado el ingreso de una parte de 


\section{Polit. crim. Vol. 12, № 24 (Diciembre 2017), Art. 13, pp. 1106-1183. [http://www.politicacriminal.cl/Vol_12/n_24/Vol12N24A13.pdf]}

mercados alternativos, tendencialmente desregulados, no deberían desempeñar un rol central en la función macroeconómica de asignación de recursos financieros desde el ahorro hacia la inversión (mercado primario). No al menos en principio, de un modo intencionado desde la legislación. Otro tanto si se busca favorecer condiciones aceptables de liquidez $^{135}$, potenciada en cambio por mercados secundarios concentrados o integrados (no dispersos o fragmentados) ${ }^{136}$. Lo opuesto sería contradictorio con los objetivos de nuestra LMV: pues precisamente a través de la regulación (primaria o no accesoria, antes que nada) se ha buscado potenciar el flujo de recursos a través de mercados lo suficientemente profundos y transparentes como para que los inversionistas vean satisfechas sus expectativas de liquidez, en base a precios-de-mercado suficientemente fiables ${ }^{137}$.

Considérese que justamente porque a través de la institución de la oferta pública de valores se busca captar masivamente recursos financieros provenientes del ahorro del público, es que se vuelve necesaria una tutela intensa de los mecanismos de formación de los precios. Un grado de protección es por cierto necesario en otros contextos de solicitud de recursos financieros, pero ya no como expresión de la tutela de un sistema regulado o institucionalizado, sino como protección de un puntual fenómeno con eventuales repercusiones patrimoniales para un círculo más o menos amplio de inversionistas (como se indicará abajo). De este modo, sólo a la luz de esta segunda estrategia de tutela podría explicarse una interpretación amplia de la fórmula valores no regidos por la LMV.

aquellos mercados (sistemas de negociación multilateral: SNM [= MTF, por su sigla en inglés: multilateral trading facilities $]$ y sistemas organizados de contratación: SOC [= OTF, por su sigla en inglés: organised trading facilities]) en el marco de las expectativas de confianza del público inversionista, por la vía de someterlos a regímenes suficientes de regulación en sede de transparencia informativa; es decir, colocándolos en el mismo perímetro de regulación basal que los mercados tradicionalmente regulados (bursátiles), evitando con ello el "arbitraje regulativo".

${ }^{135}$ Cfr. ARMOUR et Al., Principles, cit. nota n², pp. 147-148; y LONDOÑO, "Ilícito de manipulación”, cit. nota $\mathrm{n}^{\circ} 2$, pp. 74 y 77.

${ }^{136}$ Cfr. PERRONE, Il diritto del mercato, cit. nota ${ }^{\circ}$ 2, pp. 251-252. Ampliamente, cfr. MOLONEY, EU Securities, cit. nota $\mathrm{n}^{\circ} 4$, pp. 2-3 y 426 y ss.

${ }^{137}$ En este sentido considérense las constancias en el Compendio de historia de la LMV, Informe Técnico, comentando el contenido del Título $\mathrm{V}$ en materia de estructura del mercado formal: "Este artículo establece la estructura legal e institucional definitiva que tendrá el mercado secundario. En él se establece que el mercado de acciones emitidas por compañías que estén registradas en la Superintendencia queda confinado a las bolsas de valores, las que no podrán rechazar la inscripción de una acción. // Ello se debe a que la excesiva fragmentación de las cotizaciones de estos valores tanto dentro como fuera de las bolsas significaría una reducción en la liquidez de cada uno de los mercados individuales y por consiguiente aumentaría la volatilidad de ellos. Esto no es conveniente en ningún caso y menos en economías en desarrollo con mercados pequeños y frágiles como el chileno. // Por su parte, las acciones de compañías no registradas, no podrán transarse dentro de las bolsas y sólo podrán negociarse privadamente o en el mercado formal fuera de la bolsa. El objetivo de estas disposiciones es asegurar al inversionista que dentro del mercado bursátil encontrará un centro de intermediación con alto grado de liquidez y amplia información sobre empresas bastamente conocidas, que opera a través de mecanismos continuados de subasta pública. En los mercados fuera de bolsa, el grado de liquidez será probablemente menor, la información sobre las empresas podrá ser también menor y el mecanismo de operación será de negociación entre compradores y vendedores.” 
LONDOÑO, Fernando “¿Qué prohíben los artículos 52 y 53 de la Ley de Mercado

de Valores? Reconstrucción dogmática de las figuras de manipulación

de mercado en el derecho chileno".

A la luz del tipo de intereses protegidos por la LMV y especialmente en su Título VIII, la decisión de incorporar como objeto material a todo valor no regido por la LMV parece problemática, si no ya derechamente contradictoria ${ }^{138}$.

Una conclusión distinta comprometería el sentido global del inciso $2^{\circ}$ del art. 53. En efecto, no sería plausible sostener que pueda haberse seguido una estrategia para los valores regidos por la LMV y otra distinta para aquellos valores no regidos por la LMV; cual si el inciso en cuestión se desdoblara: comportándose como una prohibición estrictamente antimanipulativa tratándose de valores regidos por la LMV y como mera prohibición de engaño en contextos de solicitud de inversión, tratándose de valores no regidos por la LMV. Más coherente sería reconocer, bajo ese supuesto, que el inciso $2^{\circ}$ del artículo 52 constituiría in totum una prohibición de toda forma de engaño en contextos de solicitud de inversión, o que involucren transacciones con valores. Bajo ese predicamento volvería a aparecer la sombra de la Regla 10b-5 del derecho federal estadounidense como norma de referencia para efectos hermenéuticos ${ }^{139}$.

Ya se han ofrecido argumentos históricos y sistemáticos en sintonía con la comprensión de la propia SVS, los regulados y la doctrina, todos los cuales ponen dificultades a una lectura como la sugerida en el párrafo anterior (por más que ella siga siendo igualmente plausible,

\footnotetext{
${ }^{138}$ Como se hizo ver arriba en nota $\mathrm{n}^{\mathrm{o}} 134$, la Unión Europa ha transitado en una dirección amplificadora del alcance de la regulación sancionatoria y penal de abusos de mercado. Ello parece entonces contradictorio con la dirección en la que se coloca la interpretación aquí defendida, en tanto restrictiva. Nótese en todo caso que el movimiento regulador europeo no se ha impuesto "desde lo sancionatorio", sino - como es correcto que sea - a partir de la regulación primaria, antes que nada mediante la imposición de deberes de transparencia informativa equivalentes a los que rigen en los mercados tradicionalmente regulados (bursátiles). En ese contexto, igualado el campo en el plano de las expectativas normativas basales (desde los cimientos), puede hacer sentido la correlativa ampliación del alcance de las figuras penales. No hace sentido en cambio proponer que las figuras penales vayan "por delante" de la regulación primaria, al menos para quien sea sensible al carácter accesorio del derecho penal. Una interpretación distinta a la aquí defendida para el objeto material del art. 53 LMV correría precisamente el riesgo de invertir ese orden de cosas. Por lo que se refiere a la situación europea a partir de la ampliación del perímetro de regulación reconocido en la RAM 2014 y la DAM 2014 (en consonancia con las ampliaciones emprendidas en la regulación de base, MiFID I-II y MiFIR), cfr. MOLONEY, EU Securities, cit. nota n ${ }^{\circ}$ 4, pp. 425 y ss. y 714-716; y PERRONE, Il diritto del mercato, cit. nota $\mathrm{n}^{\circ} 2$, pp. 251-252, 269 y ss. y 283 y ss., haciendo ver cómo el regulador europeo ha debido de algún modo rendirse al creciente uso de sistemas alternativos de negociación en valores, con el consecuente mayor compromiso para el ahorro público de los ciudadanos europeos. Por lo demás, la homologación regulativa desde los cimientos, a partir de las reglas de transparencia informativa, apunta a evitar el denominado "arbitraje regulativo". Aunque se trata de un fenómeno distinto, más marginal, una preocupación por la situación de los mercados alternativos (los denominados penny stocks) se advierte también en Estados Unidos, especialmente a partir de la Penny Stock Reform Act de 1990 y la respectiva ampliación de las competencias fiscalizadoras de la propia Securities Exchange Commission [SEC], con su Microcap Fraud Working Group a partir de 2011: cfr. ANDROPHY, Joel M., White Collar Crime, Saint Paul, Minnesota: Thomson Reuters, $2^{\text {nd }}$. Ed., Vol. 2, 2011 (actualización periódica a 2016), III, §12.47, pp. 87-88. En lo demás, por su interés para esta materia, cfr. supra 2.2.1 en este trabajo, a propósito de los mercados de derivados (especialmente hacia el final del apartado, en el cuerpo asociado a las notas a pie $\mathrm{n}^{\circ} 90-92$ ).

${ }^{139}$ Cfr. LONDOÑO, "Aproximación histórico-comparada", cit. nota ${ }^{\circ} 1$, pp. 432 y ss., especialmente pp. 442-447 para la refutación de una posible lectura pseudo-asimiladora.
} 
Polít. crim. Vol. 12, № 24 (Diciembre 2017), Art. 13, pp. 1106-1183.

[http://www.politicacriminal.cl/Vol_12/n_24/Vol12N24A13.pdf]

estando al menos al tenor literal del inciso ${ }^{140}$ ). A esas razones cabe ahora sumar tres consideraciones adicionales.

En primer lugar, llama la atención que si la LMV original hubiese querido prohibir y sancionar así meras hipótesis de engaño en emisiones y transacciones con valores, no lo hubiese hecho a propósito de la incorporación -durante la tramitación del proyecto de LMV - de una prohibición especialmente dedicada a atajar la publicidad engañosa y las mendacidades en contextos de solicitud de inversión, como es el caso del art. $65 \mathrm{LMV}^{141}$.

En seguida, nótese que si efectivamente se tratase de una figura tradicional de engaño en contextos de inversión, haría poco sentido la inclusión de la "inducción a la venta" de valores como conducta típica. Lo natural hubiese sido limitar la inducción (engañosa) a invertir en valores (comprar valores). No se nos escapa que un perjuicio puede igualmente derivarse de una inducción a desinvertir o vender valores, pero ello se condice menos con la estructura de un tipo de estafa de inversión u otro semejante ${ }^{142}$.

En fin, de sostenerse una interpretación como la criticada, la aplicabilidad del pasaje en comento resultaría francamente marginal, cuanto menos en contextos de inversión en valores regidos por la LMV. En efecto, los tipos de falsedad informativa de las letras a) y f) del art. 59 LMV ofrecen una cobertura mucho más a la mano para casos semejantes; es decir, para casos de potencial engaño en solicitudes de inversión o mendacidad en cualquier tipo de información que pueda servir de antecedente para la toma de decisiones de inversión o desinversión ${ }^{143}$ (y ello sin perjuicio de la eventual aplicabilidad del tipo común

\footnotetext{
${ }^{140}$ En el contexto de la tramitación de la LMV original puede leerse en el informe de la Secretaría Técnica una descripción del Título XI, con alusión a "emisiones fraudulentas" y "engaño público", que podría considerarse compatible con esta lectura alternativa del inc. $2^{\circ}$ del art. 53. Con todo, la referencia es todavía ambigua y marginal como para que pueda asignársele algún valor en sede interpretativa. En efecto, allí se lee: "También se establecen penas de presidio en casos calificados, por infracción grave a la ley, principalmente relativas a engaño público, emisiones fraudulentas, falsedad etc." (Secretaría Técnica, p. 45 del Compendio de Historia de la LMV original).

${ }^{141}$ Véase el informe de la Secretaría de Legislación, p. 72 del Compendio de Historia de la LMV original.

${ }^{142}$ Nótese por ejemplo que justamente ésta es la situación de la $\$ 17$ (a) de la Securities Act de 1933 (15 U.S. Code $§ 77 q$ ), la que sólo sanciona hipótesis de falsedad en perjuicio de compradores de valores (falsedad en las ofertas o ventas de valores). Justamente ese vacío habría dado lugar en 1943 a la redacción de la Regla 10b-5 en los términos conocidos: cfr. al respecto, HAZEN, Thomas Lee, Securities Regulation. In a nutshell, St. Paul (MN): West (Thomson Reuters), 10th ed., 2009, pp. 153-154.

${ }_{143}$ Provisoriamente, se propone interpretar la voz antecedente de la letra a) del art. 59 LMV en clave funcional, como sinónimo de presupuesto informativo (relevante) para la toma de decisiones por parte de los inversionistas (relevante ex ante, en principio). Con ello se destaca la primacía del contenido por sobre el locus formal de la información (continente). Una lectura semejante enlaza por lo demás con las exigencias de revelación obligatoria previstas en el art. 9 y 10 inc. $2^{\circ}$, a propósito de la información esencial (precisamente aquella valorada como importante para la adopción de decisiones de inversión, de acuerdo a un estándar de inversionista juicioso). En fin, ello empalma bien con el carácter restringido de la fórmula de la letra a) del art. 59 LMV, allí donde dispone que el contexto informativo de relevancia típica es sólo aquel instaurado "para efectos de esta ley". Mutatis mutandis, a la misma clave de lectura ha de someterse el verbo certificar empleado por la letra a) del art. 59. De cualquier modo nos parece que las dificultades interpretativas que ofrecen las letras a) y f) del art. 59 LMV - de alcance objetivo y de delimitación entre sí (¿concurso aparente?) - no obstan a las conclusiones reseñadas arriba en el cuerpo, cuanto menos para los casos centrales de engaño en la inversión. En lo demás, con mayor o menor detalle, propuestas de interpretación para las letras a) y f) del art. 59 LMV pueden apreciarse en: TORRES, Angélica, "El delito de entrega de información
} 
LONDOÑO, Fernando “¿Qué prohíben los artículos 52 y 53 de la Ley de Mercado

de Valores? Reconstrucción dogmática de las figuras de manipulación

de mercado en el derecho chileno".

de estafa, para casos de interacción concreta o no difusa, antes que nada en contextos de mercado primario). La técnica de tipificación de las falsedades de las letras a) y f) facilita en efecto la acreditación de supuestos semejantes. En particular la letra f) se encuentra en sintonía con las modernas tipificaciones de falsedad de prospecto o de engaño en la solicitud de inversión, pero va más allá, en cuanto se extiende a falsedades en informaciones proporcionadas a la SVS o a la SBIF, así como a los tenedores de valores de oferta pública o en las noticias o propaganda divulgada al mercado. Con ello el alcance de la letra f) parece extenderse considerablemente, por de pronto más allá de las solas mendacidades en el mercado primario ${ }^{144}$. Que en recientes investigaciones por presuntas falsedades en contextos de oferta de instrumentos de deuda (cfr. el denominado caso La Polar) tanto la actividad de la SVS como la del Ministerio Público se haya dirigido a la acreditación de la letra f) del art 59 -en lugar de incomodar el alcance del art. 53 en comento- resulta sintomático de cuanto aquí se afirma.

Por todo lo dicho en este apartado, no persuade suficientemente una interpretación amplia del objeto material del inciso $2^{\circ}$ del art. 53, en los términos recién descritos. Considerando las consecuencias jurídicas en juego y las razones sistemáticas e históricas ofrecidas a lo largo de este trabajo, persuade más una interpretación restrictiva del alcance de la fórmula relativa al objeto material; a saber, una lectura que, además de los títulos regidos por la $L M V$, comprenda aquellos valores de índole estatal a que se refiere el inciso $2^{\circ}$ del art. 3 LMV. Esa interpretación es coherente con la lectura del art. 53 que aquí se ha defendido, cual fórmula anti-manipulativa dirigida a la tutela de la correcta formación de los precios de los valores transados en mercados regulados y, desde allí, hacia la protección de la función de asignación de recursos financieros que dichos mercados realizan en nuestra economía.

2.4.2. Segunda modalidad típica del inciso $2^{\circ}$ del art. 53 LMV: inducir o intentar inducir a la compra o venta de valores, regidos o no por esta ley, por medio de cualquier acto, práctica, mecanismo o artificio engañoso o fraudulento

a) El sentido manipulativo de la fórmula de inducción a la compra o venta de valores (mediante cualquier acto, práctica, mecanismo o artificio engañoso o fraudulento)

Ya se ha dado cuenta del carácter amplio de esta segunda variante del inciso $2^{\circ}$ del artículo 53 , lo que la coloca como una figura residual ("atrapa-todo") respecto al inciso $1^{\circ}$ y a la primera variante del inciso $2^{\circ}$. Es decir, esta fórmula captura las restantes conductas de manipulación por injerencia indirecta con recurso a modalidades de engaño.

Ello se debe a la elasticidad de la fórmula consistente en la inducción a la compra o venta de valores. Satisface la hipótesis en comento toda conducta engañosa, idónea para incidir en las decisiones de inversión o desinversión de otros (compra o venta de valores), de modo

falsa al mercado como delito base o precedente de lavado de dinero", Revista Jurídica del Ministerio Público, N.64 (septiembre 2015), pp. 199-223, respecto de ambas letras del art. 59 LMV; GARCÍA, "Equivalentes funcionales", cit. nota $n^{\circ} 67$, general respecto al art. 59; y, muy recientemente, HERNÁNDEZ, "La necesaria relevancia", cit. nota $\mathrm{n}^{\circ} 67$, fundamentalmente para la letra a) del art. 59 LMV.

${ }^{144}$ Incrementando eventuales márgenes de concurso aparente con la figura de la letra a) del mismo artículo, según se ha anticipado en la nota precedente. 
Polít. crim. Vol. 12, № 24 (Diciembre 2017), Art. 13, pp. 1106-1183.

[http://www.politicacriminal.cl/Vol_12/n_24/Vol12N24A13.pdf]

que esas actividades transaccionales puedan a su vez incidir (injerencia indirecta) en el precio-de-mercado del valor de que se trate.

Aquella fórmula representa una perífrasis, pues es induciendo a las compras que se actúa en el aumento de la demanda (y desde ahí el buscado incremento del precio-de-mercado); mientras que es induciendo a las ventas que se actúa en el lado de la oferta (y desde ahí la pretendida rebaja del precio-de-mercado). El circunloquio habría podido evitarse aludiendo a la demanda y a la oferta, instancias que representan la unidad agregada de las compras y ventas para un determinado período. Como se sostuviera en otro lugar ${ }^{145}$, en la elaboración de la norma en comento pudo haber influido la muy conocida fórmula anti-manipulativa del derecho federal estadounidense ( $\$ 9[\mathrm{a}][2]$ de la SEA'34) que precisamente se vale de la idea de inducción a la compra o venta de valores para describir la conducta (si bien como expresión de una intención trascendente y no como parte del tipo objetivo).

La inducción a comprar o vender valores deberá tender a lograr la realización de un volumen de transacciones suficientes como para que una alteración del precio-de-mercado resulte a lo menos posible ex ante, atendidas las condiciones del mercado para el respectivo valor. De otro modo difícilmente podrá afirmarse una tentativa idónea. De lo anterior se desprende que normalmente la inducción engañosa deberá dirigirse al mercado en general o a lo menos a un círculo muy amplio de inversionistas, dependiendo de las condiciones del mercado del título respectivo (dependiendo del grado de profundidad o liquidez del mismo). Se comprende en todo caso que bajo esta perspectiva podrá igualmente bastar una inducción engañosa dirigida a un inversionista con gran poder de mercado (un inversionista institucional, por ejemplo) en la medida que sus solas transacciones podrían aparecer ex ante idóneas para alterar los precios-de-mercado.

\section{b) Alcance: tipologías comprendidas bajo la segunda variante del inciso $2^{\circ}$ del art. 53}

Como ya se ha tenido ocasión de anticipar, toda suerte de manipulación informativa es subsumible en principio bajo esta fórmula (sin perjuicio del problema concursal con el art. 61 LMV, sobre el que más abajo se tomará posición). El ya comentado caso Schwager respondería a este patrón ${ }^{146}$.

Asimismo, también las manipulaciones cometidas mediante la realización de actividades extra bursátiles engañosas ${ }^{147}$ (act based manipulación) deberían considerarse comprendidas aquí. La fórmula de inducción, con su referencia a cualquier acto o práctica, da espacio para ello. Así, por ejemplo, quedaría comprendida la acción manipulativa del controlador

\footnotetext{
${ }^{145}$ LONDOÑO, “Aproximación histórico-comparada”, cit. nota n 1, pp. 414 y ss.

${ }^{146}$ A menos que se entienda que las transacciones en virtud de las cuales el Presidente de la Compañía habría aumentado su participación en la empresa operaron a modo de transacciones ficticias.

${ }^{147}$ Cfr. supra 2.4.1.a Excurso, con referencia a un posible alcance alternativo - allí rechazado en todo caso para la voz "fraudulento", que permitiría subsumir - como caso punible de action based manipulation supuestos en los que las acciones ejecutadas carezcan de valencia engañadora; es decir, supuestos en los que las conductas sean constitutivas de un delito o cuanto menos de un ilícito, precisamente ejecutado con miras a provocar cambios en el precio-de-mercado de un determinado valor (cfr. supra nota n ${ }^{\circ}$ 113: caso Borussia Dortmund). Allí se asume la exclusión de este tipo de casos como supuestos de manipulación, para ser en cambio reconocidos como potenciales casos de uso de información privilegiada.
} 
LONDOÑO, Fernando “¿Qué prohíben los artículos 52 y 53 de la Ley de Mercado de Valores? Reconstrucción dogmática de las figuras de manipulación de mercado en el derecho chileno".

que cierra temporalmente una importante planta productiva de su compañía, sin que exista una sola razón que lo explique (avería, déficit energético, costos, etc.) fuera de la de alertar a los accionistas sobre la existencia de (aparentes) deficiencias del negocio no reveladas, de modo de inducirlos a vender acciones y consecuentemente obtener una rebaja en el respectivo precio-de-mercado (lo que el controlador espera para incrementar su participación pagando menos por ello, consciente como es de que no existe deficiencia alguna en la empresa, sino todo lo contrario) $)^{148}$.

Del mismo modo, deberían considerarse comprendidas aquí aquellas manipulaciones complejas, que se valen tanto del uso de transacciones como de informaciones engañosas para alterar los precios. Así, por ejemplo, la maniobra de quien ejecuta compras a precios crecientes para generar la apariencia de un mercado activo alcista, acompañando dichas aciones con un comunicado de hecho esencial que de cuenta de (falsas) buenas noticias para el negocio del emisor ${ }^{149}$. El recurso a más de un mecanismo de manipulación es por lo demás frecuente en la práctica ${ }^{150}$, lo que permite apreciar la conveniencia del espacio típico ofrecido por el inciso $2^{\circ}$ del art. 53.

\section{c) Lecturas alternativas}

En este espacio cabe hacerse cargo de las lecturas alternativas que la fórmula de inducción del inciso $2^{\circ}$ del art. 53 ha merecido o podría merecer. La primera de ellas ha sido ya planteada en doctrina y puede responderse fácilmente, en la medida que no pone obstáculos serios a una interpretación como la aquí defendida. El segundo orden de lecturas alternativas es meramente hipotético (no han sido planteadas en nuestro medio), pero el tenor literal del inciso en comento podría plausiblemente sugerirlas. A partir de ellas la norma adquiriría un sentido diverso al que aquí se le ha dado.

i. ¿Inducción a comprar o vender valores como "inducción a cometer delitos"?

La primera lectura ha sido planteada por Alfredo Etcheberry ${ }^{151}$, quien -pese a coincidir en el alcance manipulativo de la figura- extrañamente reconoce en la fórmula (más precisamente en la tentativa de inducción) un sentido anticipador de la punibilidad de una hipótesis de autoría de la parte general del Código Penal. Concretamente aquella prevista en el art. $15 \mathrm{~N}^{\circ} 2 \mathrm{CP}$, conforme a la cual se consideran autores: (...) los que fuerzan o inducen directamente a otro a ejecutarlo.

\footnotetext{
${ }^{148}$ Cfr. ALLEN, Franklin y GALE, Douglas, "Stock-Price Manipulation”, Rev. Fin. Stud. (1992), n. 5, pp. 503-529, pp. 504-505, reportando un supuesto similar bajo la categoría de action based manipulation (cfr. el caso de la American Steel and Wire Company). En el ya citado documento de guidelines CESR/04-505b se encuentra también una hipótesis de action based bajo la rúbrica 4.14 "Dissemination of false and misleading information", letra b) "Other behaviour designed to spread false/misleading information."

${ }^{149}$ En el documento de guidelines CESR/04-505b las hipótesis de pump and dump y the trash and cashse ubicarían aquí, en la medida que el recurso a la información falsa se añade a las transacciones engañosas: cfr. la rúbrica 4.13 "Transactions involving fictitious devices/deception”, letras c) y d).

${ }^{150}$ Cfr. AVGOULEAS, The Mechanics, cit. nota ${ }^{\circ}$ 4, p. 119.

${ }^{151}$ Así, ETCHEBERRY, Derecho Penal, cit. nota no 60, p. 281. Otra opinión es defendida por ROSENBLUT, "El caso Schwager", cit. nota n 32, p. 187.
} 
Polít. crim. Vol. 12, № 24 (Diciembre 2017), Art. 13, pp. 1106-1183.

[http://www.politicacriminal.cl/Vol_12/n_24/Vol12N24A13.pdf]

Esta lectura no parece correcta. En efecto, no se advierte cómo podría asimilarse una inducción a cometer delitos con la inducción a realizar inversiones o desinversiones perfectamente lícitas ( ¡se trata de comprar o vender valores!). El inducido aquí no ha de considerarse autor directo o material de la manipulación punible (en el sentido que lo es el inducido a cometer un delito), sino más bien el comprador o vendedor incauto que, con su poder de mercado y actuando en el sentido que la inducción del manipulador sugiere, contribuye (sin saberlo) a la conquista del precio aspirado por aquel. El inducido es aquí el manipulado y no, como allá, el autor material del delito.

\section{ii. Una lectura patrimonialista}

Un segundo escenario interpretativo es imaginable a partir de una interpretación literal y parcialmente descontextualizada del inciso en comento. Igualmente, como se ha visto, a partir de la consideración de la amplitud del objeto material, (aparentemente) comprensivo de valores no transados en mercados formales (cfr. supra 2.4.1.d).

Podría así asimilársele a una figura dirigida preferentemente a la tutela del patrimonioindividual de un círculo más o menos amplio de inversionistas o potenciales inversionistas, respecto de conductas engañosas que pudieren afectarles en contextos de solicitud o propuesta de inversión en valores, ya en el mercado primario, ya en el secundario. Bajo este prisma, un contrapunto comparativo aproximado podría hallarse en figuras como la de incitación a la inversión especulativa o incitación abusiva de la inexperiencia del inversor del derecho alemán $\left(\$ \S 23.1\right.$ y 61 BörsG) ${ }^{152}$ o, en el caso de engaños de alcance más difuso, en figuras de engaño dirigido a un círculo más o menos amplio de potenciales inversionistas (como la denominada estafa de inversión del art. 264a del StGB Alemán o su símil del art. 282 bis CPEspañol y aún la falsedad de prospecto del art. 2.623 CCitaliano). Podría también pensarse en un correlato con la Regla 10b-5 del derecho federal estadounidense, en aquella parte en la que se comporta como figura de fraude en contextos transaccionales con valores (mercado secundario), excluido eso si el contenido de injusto que se relaciona con el abuso de información privilegiada, según ya se diera cuenta en otro $\operatorname{lugar}^{153}$.

Pues bien, esta segunda línea interpretativa, por más que en apariencia plausible, se ve enfrentada a importantes objeciones. Varias de ellas han sido expuestas en otro lugar a propósito del estudio histórico-comparado de la figura ${ }^{154}$, mientras que aquí se ha hecho ver que tanto la génesis normativa como la precomprensión prevaleciente en nuestro medio se ajustan mejor a una lectura en clave supra-individual (cfr. supra 1).

Bastará aquí con reafirmar que razones sistemáticas y de coherencia sancionatoria inducen a pensar que la figura en comento no ha de reducirse a la tutela de intereses patrimoniales. Con motivo del tratamiento del objeto material de este inciso (supra 2.4.1.d) se ha aportado además un argumento sistemático que aquí se reitera: una interpretación semejante dejaría

\footnotetext{
152 TIEDEMANN, Manual, cit. nota n ${ }^{\circ}$ 127, pp. 383-384 (Wirtschafts Strafrecht, BT, Ed. Carl Heymanss, Köln, 2006, p. 162).

${ }^{153}$ Cfr. LONDOÑ, “Aproximación histórico-comparada”, cit. nota n 1, pp. 437 y 438.

${ }^{154}$ Cfr. LONDOÑO, "Aproximación histórico-comparada”, cit. nota $\mathrm{n}^{\circ} 1$, passim.
} 
LONDOÑO, Fernando “¿Qué prohíben los artículos 52 y 53 de la Ley de Mercado

de Valores? Reconstrucción dogmática de las figuras de manipulación

de mercado en el derecho chileno".

al inciso $2^{\circ}$ del art. 53 un campo relativamente modesto de aplicación, en la medida que nuestra LMV dispone de figuras capaces de anticipar la tutela frente a hipótesis semejantes, de manera más cómoda y directa. Como se ha dicho, la figura de falsedad del art. 59 f) LMV ocupa un lugar central aquí, además de la figura más amplia de la letra a) del art. 59. Todo lo anterior por lo que atañe a aquellas formas de engaño difuso o de "amplio alcance" (dirigidas a un círculo indeterminado o muy vasto de inversores). Por lo que en cambio se refiere a engaños en contextos de inversión circunscritos, dirigidos a una o más personas determinadas, las tradicionales figuras de estafa (art. 468 y $473 \mathrm{CP}$ ) deberían estar en condiciones de ofrecer su protección -ya desde la tentativa por cierto- sin necesidad de incomodar al derecho bursátil. Las más moderadas sanciones de aquellas figuras del $\mathrm{CP}$ parecen por lo demás correctamente ajustadas a estos supuestos de alcance exclusivamente patrimonial, en lugar de la muy severa sanción de crimen con la que amenaza el art. 59 LMV en relación con el art. 53 en comento.

Si pudiéramos sintetizar lo afirmado hasta aquí con un "eslogan" concluyente, podríamos decir que el inciso $2^{\circ}$ del art. 53 no prohíbe engaños o falsedades en el mercado de valores en sí mismos (a modo de estafas de amplio alcance meramente tentadas), sino en la medida que esos engaños sean funcionales a la modificación de un estado de cosas por lo que toca a los precios-de-mercado ${ }^{155}$.

\subsection{Tipicidad subjetiva en las figuras penales del Título VIII}

La exigencia de dolo parece ineludible, en cuanto intrínseca a cualquier modalidad de conducta que se deje describir como manipulativa o engañosa. Por su parte, en principio no es seguro que el dolo eventual esté en condiciones de colmar la exigencia subjetiva de las figuras del Título VIII: ya porque incompatible con el dolo específico o intención trascendente exigido por el art. 52 (con el objeto de estabilizar, fijar, etc.), ya porque

\footnotetext{
${ }^{155}$ Dos lecturas alternativas adicionales podrían todavía considerarse aquí, en ambos casos rechazándose su adopción. En primer lugar, quien todavía quiera esgrimir la alternativa patrimonialista, deberá reconocer que ni aún bajo aquella puede tener cabida una lectura del inciso $2^{\circ}$ del art. 53 - tanto de su primera como de su segunda variante - que dé cabida a alguna forma de defraudación no auto-lesiva o "colateral"; esto es, no tendrá cabida una conducta que no se dirija a perjudicar a aquel sobre el que actúa el engaño (el engañadoperjudicado) o a una parte a quien este engañado represente, disponiendo patrimonialmente por su cuenta, de modo que el supuesto cuente como uno de "auto-lesión" (engaño triangular). En lo demás, cfr. supra 2.4.1.ac. En seguida, tampoco resulta aceptable una lectura que pretenda ver una infracción al inciso $2^{\circ}$ del art. 53 con las gravísimas consecuencias penales a partir del art. 59 e) LMV - a partir de la mera elusión o infracción de una normativa técnico-procedimental de tipo bursátil u otra similar (como por ejemplo el art. 126 del Reglamento de la Bolsa de Comercio). Dicha elusión o infracción podrá ser bastante para configurar un elemento de la prohibición (un artificio, en los términos del inciso $2^{\circ}$ del art. 53), pero con ello no puede darse por satisfecha la prohibición en su integridad. Estando al tenor literal del inciso, el artificio (engañoso o fraudulento) constituye solo un mecanismo o recurso medial de la fórmula, pero no su fin. Lo que la fórmula íntegramente considerada exige es que mediante ese artificio - desde ahí - se induzca a otros a comprar o vender acciones. La verificación de una transacción artificiosa en los términos antes expuestos (elusiva o infractora de una norma procedimental cualquiera) no puede contar como medio y como fin, a la vez, sin que con ello se vulnere el tenor literal de la disposición. Como se dijera supra 1.2.2.c), a una conclusión semejante se arriba si se atiende a las consideraciones incluidas en la Reglas del Comité de Autorregulación (Reglas, cit., p. 16). Entre otras razones, en estas consideraciones se radica nuestra discrepancia con la posición sentada por la Excma. Corte Suprema en el caso Inverlink-Corredoras (cfr. supra 1.2.1).
} 
Polít. crim. Vol. 12, № 24 (Diciembre 2017), Art. 13, pp. 1106-1183.

[http://www.politicacriminal.cl/Vol_12/n_24/Vol12N24A13.pdf]

fenomenológicamente poco conforme con la dirección manipulativa reconocida como sustrato del art. 53, ya porque en pugna con la mecánica de inducción a que se refiere la segunda fórmula del inciso $2^{\circ}$ del art. 53; en fin, porque escasamente concebible en supuestos elaborados de engaño como los que plantean las conductas del art. 53 en general. Considérese además que en nuestra doctrina penal tiende a ser dominante la tesis que rechaza la compatibilidad del engaño con el dolo eventual ${ }^{156}$. De todos modos se ofrecerá una visión más detallada en los apartados dedicados a la lectura lineal del tipo penal del art. 59 e) LMV (infra 3).

\subsection{Sobre el art. 61 LMV y su problemática posición}

Más arriba (cfr. supra 1.2.1.b., nota al pie $\mathrm{n}^{\mathrm{o}}$ 41) se ha tenido ocasión de advertir la problemática posición del tipo penal del art. $61 \mathrm{LMV}$, cuyo texto se transcribe aquí:

Artículo 61. El que con el objeto de inducir a error en el mercado de valores difunda información falsa o tendenciosa, aun cuando no persiga con ello obtener ventajas o beneficios para sí o terceros, sufrirá la pena de presidio menor en sus grados mínimo a medio.

La pena señalada en el inciso precedente se aumentará en un grado, cuando la conducta descrita la realice el que en razón de su cargo, posición, actividad o relación, en la Superintendencia o en una entidad fiscalizada por ella, pudiera poseer o tener acceso a información privilegiada.

Del tenor literal del inciso $1^{\mathrm{o}}$ se desprende un claro sentido anti-manipulativo. Eso no parece estar en discusión y, como se ha visto, la propia SVS ha recurrido a esta figura para sancionar conductas que, desde un punto de vista criminológico, resultan asimilables a modalidades de manipulación informativa (cfr. supra 1.2.1.b, caso Schwager). ¿Cómo se compatibiliza entonces esta figura penal con el art. $53 \mathrm{LMV}$, en relación con la letra e) del art. 59? Considérese además que en el caso del art. 61 la pena es de simple delito (61 días a 3 años de presidio), mientras que el art. 59 sanciona la infracción del art. 53 con una pena de crimen, significativamente superior (541 días a 10 años de presidio). ¿Cómo se explica esta diferencia penológica, en circunstancias que una y otra figuras se dirigirían a prohibir conductas semejantes ${ }^{157}$

Si se buscase una diferencia en la calidad o posición de obligado especial del sujeto activo, ésta no se encontraría. No hay exigencias de sujeto activo especial en los arts. 53-59 e), mientras que tampoco las hay en el tipo base del art. $61^{158}$. Por otra parte podría haberse

\footnotetext{
${ }^{156}$ A propósito de la discusión en materia de estafa, por todos y aunque él mismo se ubica a favor de la tesis minoritaria, cfr. HERNÁNDEZ, Héctor, “Aproximación a la problemática de la estafa. Problemas actuales de Derecho Penal”, en: AAVV., Problemas actuales en Derecho Penal, Temuco: Universidad Católica de Temuco, 2003, pp. 147-190, p. 188.

${ }^{157}$ Como la solución penal del caso Schwager lo demostraría, el inc. $2^{\circ}$ del art. 53 está en condiciones de abarcar el contenido manipulativo-informativo del art. 61.

${ }^{158}$ Sin considerar por cierto la agravación del inciso segundo, introducida por la ley $\mathrm{N}^{\mathrm{o}} 20.382$ de gobiernos corporativos de 2009, que vino a problematizar aún más la situación. En efecto, antes de esta reforma podría haberse pensado en una interpretación que, supuesto el concurso aparente, excluyera del tratamiento privilegiado del art. 61 a los sujetos obligados, aplicándose siempre a su respecto la figura del art. 59 e) LMV
} 
LONDOÑO, Fernando “¿Qué prohíben los artículos 52 y 53 de la Ley de Mercado

de Valores? Reconstrucción dogmática de las figuras de manipulación

de mercado en el derecho chileno".

visto una diferencia en el formato o contexto trasmisor de la información, desde que el original art. 61 hablaba sólo de "noticias" (falsas o tendenciosas). Sin embargo la ley $\mathrm{N}^{\circ}$ 20.382 de 2009 eliminó esa alternativa interpretativa, sustituyendo la voz "noticias" por la más genérica "informaciones"

Así las cosas, resulta fácil ceder a la tentación de renunciar a alguna clave de solución, para simplemente acusar un mero defecto legislativo. Ese camino debe sin embargo evitarse, en lo posible. Puede en cambio intentarse una explicación como la que sigue.

En primer lugar, considérese que en el proyecto de LMV la fórmula equivalente al vigente art. 61 inc. $1^{\circ}$ estaba contenida en el artículo 58, con una redacción parcialmente distinta a la actual y bajo un marco penológico equivalente al supuesto de infracción del vigente art. 53 (entonces art. 48). Así, el art. 58 del proyecto original sancionaba con la misma pena de crimen hoy prevista por el art. 59-a) a:

“(e).- Las personas que con el objeto de inducir a error en el mercado difundieren noticias falsas

(f).- Las personas que infrinjan las prohibiciones consignadas en el artículo 48 [art. 52 y 53 del texto vigente] del presente decreto ley."

En el curso de la tramitación del proyecto, la regulación del Título VIII se amplió con la incorporación del inciso $1^{\circ}$ del art. 52 actual, seguramente para hacer explícita la cobertura de las manipulaciones operativas propias (transacciones reales), según se ha sostenido más arriba (cfr. supra 1.1). Por su parte, la letra e) recién transcrita pasó a formar el art. 61, con la redacción que tenía hasta la ley $\mathrm{N}^{\mathrm{O}} 20.382$ (y la letra f] pasaría a ser la letra e] actualmente vigente).

Pues bien, la ampliación del alcance de la manipulación operativa en el título VIII pudo haber servido para advertir que la fórmula del inciso $2^{\circ}$ del art. 53 estaba en perfectas condiciones de abarcar cualquier otra forma de manipulación no alcanzada por el art. 52 (la manipulación informativa por de pronto). Así, la fórmula manipulativa de la letra e) del art. 58 recién transcrito perdía su sentido. Razonablemente, habría debido suprimirse. Sin embargo, se optó por modificar la fórmula, en una tentativa por edulcorarla o ampliar su alcance "hacia abajo"; esto es, dando con una redacción que parecía dar cabida a hipótesis menos intensas de manipulación o criminológicamente menos comprometidas (en la medida que no suponen actividades transaccionales ni expectativas de lucro).

en relación con el inciso segundo del art 53. Este camino hoy ya no es transitable. De interés es en este contexto la tesis propuesta por HERNÁNDEZ, "La necesaria relevancia", cit. nota $\mathrm{n}^{\circ} 67$, passim.: en la medida que lee el tipo del art. 61 LMV como figura residual del tipo del art. 59 a) LMV - interpretado también como figura de manipulación informativa "en sentido amplio" - queda en condiciones de justificar la diferencia penológica en el distinto status de los sujetos activos: especialmente obligado en el caso del art. 59 a) y no especialmente obligado para el art. 61 LMV: cfr. op. cit., pp. 110-111. Más allá de que pueda ser problemática una asociación del tipo del art. 59 a) con el nomen iuris de manipulación informativa (al respecto cfr. supra nota $\mathrm{n}^{\circ}$ 67), la limitación de la tesis es que deja sin explicación la problemática relación con el art. 53 LMV (vía art. 59 e]), que el propio autor no descarta como figura capaz de captar hipótesis de manipulaciones informativas (op. cit., pp. 112 y 117).

${ }^{159}$ Art. $1^{\circ}$ núm. 21 de la ley $\mathrm{N}^{\circ} 20.382$, sustituyendo el art. 61 original por el texto hoy vigente. 
Así se explicaría el nuevo pasaje "aun cuando no persiga con ello obtener ventajas o beneficios para sí o terceros" (ausente en la redacción del proyecto) y la inclusión de la más tenue voz "tendenciosa", en disyuntiva al carácter derechamente falso de las noticias típicas. Considerando que el objeto material se reducía entonces a "noticias", es imaginable que una disposición semejante se haya concebido especialmente para dar cabida a hipótesis de mala praxis periodística, ampliamente discutidas en literatura y no infrecuentes en este sector (el propio caso Schwager vendría a confirmar aquello años más tarde: cfr. supra 1.2.1.b). En compensación, se mitigaron significativamente las consecuencias sancionatorias, rebajando la figura a simple delito. De este modo, una hipótesis que en el proyecto original se sancionaba con pena de hasta 10 años de presidio, pasó a sancionarse con una pena de 61 días a 3 años de presidio.

Cualquiera puede darse cuenta que la tentativa de "mitigación" que el nuevo art. 61 LMV representaba -según la reconstrucción recién propuesta- no logra ir más allá de la pena. Por lo que se refiere al tipo, éste seguiría en condiciones -estando a su tenor literal, especialmente a partir de las modificaciones introducidas por la Ley $\mathrm{N}^{\circ} 20382$ - de atrapar conductas de manipulación informativa fuertemente distorsionadoras de los precios o criminológicamente muy comprometidas. Toca sin embargo al intérprete reconducir la lectura del art. 61 de modo que se ajuste mejor al contexto sistemático y a la diversa valoración penológica, procurando reducir los contornos del concurso de normas.

De este modo $-\mathrm{y}$ con esto se ofrece una propuesta interpretativa- el art. 61 LMV ha de leerse de manera que sólo de cobertura a hipótesis en las que haya de excluirse un dolo directo referido a la (mediata) alteración de los precios. De darse en cambio ese supuesto, se estará ante la infracción del art. 53 inc. $2^{\circ}$, con la consecuente configuración de la figura penal del art. 59 e) LMV. Por tanto, en el art. 61 el dolo directo (condicionado por la exigencia de intención trascendente) se agotaría en la (inmediata) búsqueda de error en el mercado. Desde ya eso debería facilitar la prueba del delito, sin duda. En cuanto a la faz objetiva, se trataría de dar cobertura a hipótesis de inducción a error "menos comprometidas", "menos intensas" o "más distantes" por lo que se refiere a su idoneidad para afectar los mecanismos de formación de los precios-de-mercado. Por de pronto, esto se verificará allí donde se aprecien falsedades sobre las que -ya por el contenido de la información, ya por el contexto de difusión- no pueda decirse que tiendan a inducir al público inversionista a comprar o vender valores en un determinado sentido ${ }^{160}$. Es decir, casos en los que la inducción a operar en el mercado aparezca como meramente hipotética. Como se ha dicho más arriba, aquí podrían ubicarse casos de mala praxis-periodística u otros similares.

\section{Lectura lineal del tipo penal del art. 59 e) LMV en relación con los arts. 52 y 53}

Llegados a este punto no resta más que capturar el núcleo de la tesis defendida en materia de interpretación del Título VIII LMV, ofreciendo una lectura lineal (de corte manualístico) del tipo penal del art. 59 e), en relación con las prohibiciones de los arts. 52 y 53. Tratándose de una recapituación, los fundamentos o las demostraciones se reducirán al

\footnotetext{
${ }^{160}$ Con todo, ha de reconocerse que esta línea interpretativa se vería robustecida si la disposición aludiese al "público" o al "medio" en general como destinatario del engaño, y no al "mercado", como de hecho hace.
} 
LONDOÑO, Fernando “¿Qué prohíben los artículos 52 y 53 de la Ley de Mercado

de Valores? Reconstrucción dogmática de las figuras de manipulación

de mercado en el derecho chileno".

mínimo posible, pudiendo el lector redirigirse al cuerpo del trabajo para detalles al respecto. Otro tanto cabe decir respecto a las notas bibliográficas.

Como se sabe, con penas de presidio menor en su grado medio a presidio mayor en su grado mínimo (541 días a 10 años) ${ }^{161}$, el tipo de la letra e) del art. 59 LMV castiga a cualquiera que (se trata de un tipo común, con sujeto activo indeterminado) realice -entre otras hipótesis- conductas infractoras de las prohibiciones de los arts. 52 y 53 LMV (Título VIII LMV). La técnica empleada por el legislador es la de una ley penal en blanco impropia, de manera que el contenido del tipo (la conducta) se halla en las normas legales de prohibición. A ellas se dedicará lo que sigue del análisis.

Antes de proseguir, recuérdese que las aludidas disposiciones rezan:

a. [Art. 52 inc. $1^{\circ}$ " "Es contrario a la presente ley efectuar transacciones en valores con el objeto de estabilizar, fijar o hacer variar artificialmente los precios".

b. [Art. 53 inc. $1^{\circ}$ ] "Es contrario a la presente ley efectuar cotizaciones o transacciones ficticias respecto de cualquier valor, ya sea que las transacciones se lleven a cabo en el mercado de valores o a través de negociaciones privadas".

c. [Art. 53 inc. $2^{\circ}$ ] "Ninguna persona podrá efectuar transacciones o inducir o intentar inducir a la compra o venta de valores, regidos o no por esta ley, por medio de cualquier acto, práctica, mecanismo o artificio engañoso o fraudulento".

\subsection{Aspectos generales. Concepto de manipulación y taxonomías implícitas en los arts. 52 y 53 LMV}

Como primera cuestión general, debe decirse que la propuesta interpretativa ofrece un sentido unitario de antijuridicidad material para el Título VIII LMV, en el que los arts. 52 y 53 se explican y coordinan de manera de asegurar protección a todas las formas de manipulación del mercado de valores conocidas en la literatura y en la praxis ${ }^{162}$. Como se ha explicado en el cuerpo del trabajo, esta construcción es armónica con la génesis del Título VIII, pero también con el contenido de la jurisprudencia, las regulaciones de Bolsa y la literatura disponible en nuestro medio. En fin, en otro lugar ${ }^{163}$ se ha ubicado el Título VIII en un contexto comparado, demostrándose su sintonía con las fórmulas antimanipulativas de uso corriente, tanto en el derecho federal estadounidense como en el derecho comunitario-europeo de abusos de mercado.

\footnotetext{
${ }^{161}$ La lectura defendida en este trabajo - que presiona hacia arriba el contenido de injusto del Título VIII LMV - tiene la ventaja de ofrecer mejores razones para explicar la elevada penalidad asociada a la infracción de las prohibiciones: con una pena en rango de crimen, en una banda no lejana a crímenes contra la vida, la integridad física o la libertad ambulatoria (y por cierto superiores a los delitos patrimoniales tradicionales).

${ }^{162}$ Sin perjuicio de la dudosa subsunción de ciertas hipótesis extra-bursátiles, como la del mercado OTC de derivados (cfr. supra 2.2.1 y 2.4.1.d), así como de la exclusión de las injerencias por vías de hecho genéricamente ilícitas o delictivas (no engañosas), que no han de valorarse como manipulaciones, sino como hipótesis de uso de información privilegiada, en su caso (cfr. supra 2.4.1.a. Excurso).

${ }^{163}$ Cfr. LONDOÑO, “Aproximación histórico-comparada”, cit. nota $n^{\circ} 1$, passim.
} 
Polít. crim. Vol. 12, № 24 (Diciembre 2017), Art. 13, pp. 1106-1183.

[http://www.politicacriminal.cl/Vol_12/n_24/Vol12N24A13.pdf]

Con el término manipulación del mercado de valores la literatura especializada describe en general toda conducta ejecutada con la intención de injerir, artificialmente, en el preciode-mercado de instrumentos financieros transados en un mercado de valores ${ }^{164}$.

Considérese al efecto la siguiente definición de manipulación:

“(...) manipulación de valores (...) significa una conducta dirigida a [1] inducir a personas a negociar un valor o bien a [2] forzar su precio a un nivel artificial”,165

En las alternativas (1) inducción a negociar y (2) forzamiento del precio se capta una dicotomía taxonómica decisiva para ubicar el sentido de las prohibiciones de los arts. 52 y 53, atendiendo al mecanismo de injerencia en los precios-de-mercado. Así, la injerencia en los precios puede buscarse de modo indirecto (a través de negociaciones inducidas, mediante engaño ${ }^{166}$, las que a su turno condicionarán el movimiento de los precios-demercado en el sentido buscado por el inductor o manipulador) o bien de manera directa (forzando el movimiento de los precios-de-mercado mediante el ejercicio de un poder de mercado). A esta dicotomía responden perfectamente los arts. 52 (injerencia directa) y 53 (injerencia indirecta).

Ahora bien, si se examinan dichas prohibiciones con mayor detalle, se obtiene que el inciso $1^{\circ}$ del art. 52 y los incisos $1^{\circ}$ y $2^{\circ}$ del art. 53 de la $L_{M V}{ }^{167}$ representan una compacta tríada de fórmulas anti-manipulativas, complementarias entre sí. En conjunto, y con el auxilio del art. 59 e) LMV, estas tres fórmulas dan cobertura penal (y administrativo-sancionatoria) a cada una de las modalidades que en la literatura económica y en el derecho comparado se reconocen como tipologías centrales de manipulación del mercado de valores; a saber: manipulaciones operativas propias (trade-based manipulation), bajo un presupuesto de injerencia directa sobre el precio-de-mercado (art. 52. inc. $1^{\circ}$ ); manipulaciones operativas impropias (fictitious trade-based), bajo un presupuesto de injerencia indirecta sobre el precio-de-mercado (art. 53 inc. $1^{\circ}$ ); y manipulaciones de hecho (action based), manipulaciones informativas (information based) y otras de tipo operativo impropias, siempre de injerencia indirecta sobre el precio-de-mercado, como por ejemplo aquellas que combinan estrategias informativas y operativas (art. 53. inc. $2^{\circ}$ ). Para otros detalles, un cuadro sintético puede apreciarse en la introducción de este trabajo.

Corresponde ahora analizar por separado los elementos de cada sub-tipo del art. 59 e) LMV.

\subsection{Sub-tipo constituido por el art. 59e)-52 LMV}

\subsubsection{Tipo objetivo}

\footnotetext{
${ }^{164}$ Las referencias bibliográficas pueden verse supra nota $n^{\circ} 4$.

165 THEL, "The Original", cit. nota $\mathrm{n}^{\mathrm{o}} 5$.

${ }^{166}$ Cfr. lo dicho supra 2.4.1.a. Excurso en relación con la exigencia de engaño.

${ }^{167}$ A los que debe sumarse el campo de cobertura del art. 61 LMV; al respecto, cfr. supra 2.6.
} 
LONDOÑO, Fernando “¿Qué prohíben los artículos 52 y 53 de la Ley de Mercado

de Valores? Reconstrucción dogmática de las figuras de manipulación

de mercado en el derecho chileno".

El sub-tipo constituido por los arts. 59e)-52 LMV se hace cargo de las manipulaciones operativas propias (actual trade based manipulation), según se ha anticipado, como forma de injerencia directa sobre las cotizaciones de valores. En concreto, la conducta típica consiste en la realización de "transacciones en valores" (de modo que no bastaría una sola transacción, en principio) bajo un presupuesto subjetivo especial de intención trascendente, connotado explícitamente por el uso de la fórmula "con el objeto de estabilizar, fijar o hacer variar artificialmente los precios". Se trata por tanto de un tipo de resultado cortado, cuya consumación no requiere la efectiva alteración de los precios (por más que una alteración efectiva será lo habitual, en la práctica). Las transacciones habrán de realizarse de un modo ex ante idóneo para impactar en las cotizaciones del respectivo valor, en el sentido buscado por el agente: ya por fisonomía o condiciones del mercado, volúmenes transados, precios adoptados u horarios empleados.

Como se ha argumentado en el cuerpo del trabajo, objeto de la intención trascendente ("los precios" cuya estabilización, fijación o alteración se busca) es el precio-de-mercado, con referencia a las cotizaciones del respectivo valor (entre otras razones sistemáticas ya expuestas, esto es así pues de otro modo no se capta la relación medial entre la conducta transacciones realizadas-y el objetivo perseguido). Por consiguiente, cuando se alude a un precio artificioso o artificial, se quiere indicar un precio-de-mercado manipulado y no un mero precio-de-transacción anómalo. Se comprende así, pues de otro modo toda transacción realizada a un precio-fuera-de-mercado sería sin más considerada manipulativa (porque "artificiosa o artificial"). Ello resultaría un despropósito sin precedentes en ningún modelo comparado ${ }^{168}$. Este mismo predicamento vale para las figuras del artículo 53, in totum.

No es clara la distinción entre el objetivo estabilizador y el objetivo de fijación (ambos apuntarían a evitar una variación gobernada por el juego del mercado), pero podría sostenerse una distinción basada en la duración del control sobre el precio: circunscrito a un intervalo relativamente corto de tiempo, en el intento de estabilización; con tendencia a sostenerse en un intervalo más amplio de tiempo, en el intento de fijación. Esta distinción hace sentido de cara a la autorización o justificación del inciso $2^{\circ}$ del art. 52, si se considera que en general las regulaciones comparadas autorizan estabilizaciones sólo en períodos acotados, pre-definidos, jamás de manera indefinida. La distinción podría complementarse mirando por otra parte a la intensidad del control: en base a bandas, más o menos flexibles, en el intento de estabilización; pétreo o preciso, en el intento de fijación. El intento de variación es auto-explicativo y opera tanto con tendencia al alza como a la baja.

Interés presenta el adverbio "artificialmente" (referido a los tres sentidos de la intención trascedente: estabilización, fijación, variación). Con él se habría buscado enfatizar el contenido manipulativo del impulso transaccional, precisamente para distinguir estas transacciones de aquellas tendencialmente lícitas, ejecutadas pese a representarse el agente su efecto en las cotizaciones (en el precio-de-mercado). Podría haber bastado con la

\footnotetext{
${ }^{168}$ Ello no obsta por cierto a que la presencia de una o más transacciones a precios anómalos sirva de base para que pueda plantearse una indagación dirigida a verificar las razones tras dicha anomalía; cuanto más si las transacciones aparecen ex ante idóneas para incidir en el precio-de-mercado.
} 
Polít. crim. Vol. 12, № 24 (Diciembre 2017), Art. 13, pp. 1106-1183.

[http://www.politicacriminal.cl/Vol_12/n_24/Vol12N24A13.pdf]

exigencia de intención trascendente ("con el objeto de"), pero el énfasis del adverbio es bienvenido. Así, no puede quedar duda que la prohibición sólo alcanza a transacciones carentes de una racionalidad económica distinta a la que supone la tentativa de afectación del precio-de-mercado (a diferencia de aquellas transacciones lícitas, gobernadas por una racionalidad de inversión o desinversión; y aún de aquellas "diversamente ilícitas", nomanipulativas). La problemática distinción entre transacciones manipulativas y transacciones no-manipulativas es una preocupación constante en el sector, en la literatura y en la praxis, de modo que no sorprende que el legislador haya recurrido a este adverbio para dilucidar ulteriormente el punto.

En este contexto deberían considerarse pacíficamente subsumibles todas las formas de manipulación directa de tipo disruptivo. Problemática en cambio resulta la subsunción de aquellas manipulaciones que se valen de acaparamiento y abuso de posición, características en los mercados de derivados (con detalle cfr. supra 2.2.1, última parte).

\subsubsection{Tipo subjetivo}

En cuanto al tipo subjetivo, ya se ha dicho que en principio sólo es compatible con el dolo directo, en consonancia con la exigencia de intención trascendente manipulativa.

\subsubsection{Justificante especial}

En fin, y como se ha anticipado, el inciso $2^{\circ}$ del art. 52 ofrece un espacio de justificación (requerido de complementación por normativa reglamentaria-SVS) para determinadas estabilizaciones: sólo en el mercado primario o de primera emisión. El fundamento de la justificante se halla precisamente vinculado a ese contexto: es decir, en una autorización para suplir artificialmente el lado de la demanda (compras), dada la presión depresiva del precio que la oferta de valores en primera emisión tiende a generar (allí donde la voluminosa oferta de títulos supere a la demanda por aquellos).

La existencia de esta justificante -aquí- no hace más que confirmar que la prohibición del artículo 52 alcanza a las manipulaciones operativas propias (realizadas mediante transacciones reales). Nótese que esta autorización se hallaba originalmente en el art. 48 del proyecto de LMV (= art. 53 vigente), lo que por otra parte confirma que la primera variante del art. 53 vigente pretendía igualmente hacerse cargo de las manipulaciones operativas propias (cfr. supra 1.1). Y con ello ya puede pasarse al examen del siguiente sub-tipo.

\subsection{Sub-tipo constituido por el art. 59e)-53 LMV}

Cabe aquí distinguir entras las conductas prohibidas del inciso $1^{\circ}$ y las del inciso $2^{\circ}$, si bien ambas en estrecha afinidad: en relación de especialidad, según se ha explicado latamente (cfr. supra 2.3).

\subsubsection{Art. 53 inc. $1^{\circ} \mathrm{LMV}$}

a) Tipo objetivo 
LONDOÑO, Fernando “¿Qué prohíben los artículos 52 y 53 de la Ley de Mercado de Valores? Reconstrucción dogmática de las figuras de manipulación de mercado en el derecho chileno".

En contraste con el art. 52 (que cubre maniobras transaccionales reales con miras a la manipulación de los precios-de-mercado), el inciso $1^{\circ}$ del art. 53 da especial cobertura a maniobras transaccionales ficticias (fictitious-trade-based manipulation), como forma de injerencia indirecta sobre las cotizaciones de valores.

La prohibición no se infringe con las solas transacciones o cotizaciones ficticias, sino en la medida que ellas sean funcionales (idóneas ex ante, por de pronto) para alterar el precio-demercado de los respectivos valores. Ello resulta del reconocimiento de la antijuridicidad material arriba explicada (manipulativa) y es armónico con la lectura ofrecida por los Reglamentos de las Bolsas de Comercio de Santiago y Electrónica de Chile, según se explicará a continuación. Por otra parte, esta interpretación es consistente con la génesis de la disposición (art. 48 original) y la notable sintonía con la §9(a)(1) de la SEA'34 del derecho federal estadounidense (que explícitamente se hace cargo de las modalidades clásicas de manipulación mediante operaciones ficticias, como las wash-sales/purchases o las matched orders). En fin, bajo esta lectura resulta posible distinguir la conducta típica del art. 53 inc. $1^{\circ}$ de un mero contrato simulado, como el del art. $471 \mathrm{~N}^{\circ} 2 \mathrm{CP}$ y explicar la radical diferencia de penas entre aquellas figuras (multa o 61 a 540 días de presidio, en el caso del contrato simulado del CP, y presidio de 541 días a 10 años, bajo el supuesto del art. 53-59e LMV). En el cuerpo del trabajo se ofrecieron ejemplos concretos que demuestran la impertinencia de una interpretación distinta (como por ejemplo aquella que considere subsumible en el art. 53 el caso de quien simula la enajenación de un reducido número de acciones con la finalidad de evadir obligaciones alimentarias).

La conducta típica es alternativa: (1) falsificar o alterar las cotizaciones o (2) efectuar transacciones ficticias.

En cuanto a la primera alternativa (1), la parca fórmula "efectuar cotizaciones ficticias" ha de interpretarse como aquí se propone, de manera coincidente con la reinterpretación de los Reglamentos de las Bolsas; en efecto, allí se explicita el sentido anti-manipulativo del inc. $1^{\circ}$ del art. 53, reemplazando la parca fórmula "efectuar cotizaciones ficticias" por la prohibición de "cualquier maniobra tendiente a alterar artificialmente las cotizaciones de bolsa" (arts. 66 y 64 de los mencionados Reglamentos, respectivamente). Por cotizaciones ha de entenderse el reflejo público (publicado) de los precios de los valores transados en la bolsa (cfr. art. 45 letra d] LMV). Esta modalidad de manipulación es por lo demás bien conocida en la literatura (las painting the tape) y representa una forma radical de manipulación operativa impropia, en cuanto la falsificación no requiere ya ni aún una apariencia de transacción ejecutada, sino que se ejerce directamente sobre los reportes de precios o de transacciones.

En cuanto a la segunda conducta (2), por transacciones ficticias han de entenderse transacciones carentes de consecuencias económicas o no representativas de una real interacción transaccional (transacciones aparentes), como las que ejecuta una unidad jurídica-económica contra sí misma (por ejemplo, a través de dos corredoras, en dos bolsas distintas: wash sales/purchases) o bien las que se ejecutan entre partes concertadas, a 
Polít. crim. Vol. 12, № 24 (Diciembre 2017), Art. 13, pp. 1106-1183.

[http://www.politicacriminal.cl/Vol_12/n_24/Vol12N24A13.pdf]

"suma cero", es decir, de un modo que deje a todas las partes en la misma posición de valores/utilidad anterior a las transacciones (matched orders).

Ambas modalidades de conducta son especialmente idóneas para transmitir señales falsas al mercado (y con ello para manipular sus precios): pues tanto las transacciones como las cotizaciones ficticias transmiten información a los inversionistas sobre las condiciones del mercado de un determinado título. Las falsas transacciones o cotizaciones pueden por ejemplo aparentar una efervescencia alcista por el título (si se realizan falsas compras a precios progresivamente crecientes, por ejemplo) o bien aparentar una corrida depresiva (si se realizan falsas ventas a precios progresivamente descendientes, por ejemplo). La apariencia alcista o depresiva induce al inversionista a comprar o a vender en el sentido que el manipulador busca, con la ulterior alteración del respectivo precio-de-mercado. Con esto se comprende que el inciso $1^{\circ}$ del art. 53 no representa más que un caso específico del tipo de conducta cubierto por el más amplio inciso $2^{\circ}$. Sobre esto se volverá enseguida.

En cuanto al contexto de las transacciones ficticias, ellas serán típicas tanto si se realizan en el mercado de valores (mercado secundario normalmente), como si se realizan a través de negociaciones privadas. Se reputan transacciones privadas "todas aquellas transacciones de valores que [no] tengan su origen en ofertas públicas de los mismos o que [no] se efectúen con intermediación por parte de corredores o agentes de valores" (art. $1^{\mathrm{o}}$ inc. $1^{\mathrm{o}}$ LMV, leído en negativo). La inclusión aquí de este tipo de transacciones hace sentido desde un punto de vista funcional: pues el conocimiento de las transacciones privadas por parte del resto de los inversionistas puede también tener un efecto condicionante de su percepción y comportamiento (y con ello un influjo en el precio-de-mercado).

En lo demás valen algunas observaciones formuladas a propósito del art. 52: tampoco se trata aquí de una figura de resultado (no se requiere una efectiva alteración de los preciosde-mercado) y debe por cierto manifestarse una idoneidad manipuladora ex ante, cuya prueba será posiblemente más problemática tratándose de transacciones ficticias privadas.

\section{b) Tipo subjetivo}

En comparación a la conducta del art 52 esta hipótesis no ofrece una resistencia frontal al dolo eventual, en la medida que una intención trascendente no es explícita. La compatibilidad del dolo eventual merece un análisis que distinga al menos dos dimensiones del tipo objetivo. Por una parte el dolo eventual parece fenomenológicamente incompatible con la conducta misma: ¿pueden acaso concebirse hipótesis de transacciones ficticias o falsificaciones de cotizaciones no realizadas con dolo directo, cuanto más considerado el grado de complejidad y coordinación que supone una maniobra idónea para alterar los precios-de-mercado? La resistencia a esta forma de dolo en nuestro medio -quiero decir, tratándose de conductas connotadas por un factor de engaño-daría un argumento adicional a la tesis de la incompatibilidad. En cambio, la dirección manipulativa de la conducta (la proyección hacia un resultado) podría soportar un dolo eventual. Su compatibilidad parece sin embargo más bien teórica, poco acorde con la fenomenología de las manipulaciones de precios. 
LONDOÑO, Fernando “¿Qué prohíben los artículos 52 y 53 de la Ley de Mercado

de Valores? Reconstrucción dogmática de las figuras de manipulación

de mercado en el derecho chileno".

c) Justificantes especiales del art. 53 (válido para ambos incisos)

No las hay. En la medida que se tipifican manipulaciones operativas impropias (transacciones ficticias, aparentes o engañosas), no hay especio para una justificante de estabilización como la que opera para las manipulaciones operativas propias (transacciones reales) del art. 52.

\subsubsection{Art. 53 inc. $2^{\circ}$ LMV}

a) Tipo objetivo

Según se ha anticipado, el inciso $2^{\circ}$ del art. 53 representa una fórmula general respecto a la especial del inciso $1^{\circ}$, ambas mancomunadas en torno a la prohibición de formas manipulativas de injerencia indirecta sobre el precio-de-mercado. Si el inciso $1^{\circ}$ se dedica a las hipótesis de manipulación operativa impropia, el inciso $2^{\circ}$ cubre todas las demás formas de manipulación de injerencia indirecta; a saber: manipulaciones de hecho o basadas en actividades engañosas extra bursátiles (action based manipulation), manipulaciones informativas (information based) y cualquier otra modalidad de injerencia indirecta sobre el precio-de-mercado, como por ejemplo aquellas que operan mediante la combinación de transacciones (reales o falsas) e informaciones falsas (algo frecuente en la praxis).

Atendiendo al solo tenor literal del inciso, es posible distinguir dos conductas alternativas: (1) "efectuar transacciones (...) por medio de cualquier acto, práctica, mecanismo o artificio engañoso o fraudulento"; (2) "inducir o intentar inducir a la compra o venta de valores (...) por medio de cualquier acto, práctica, mecanismo o artificio engañoso o fraudulento".

Como se ha expuesto latamente en el cuerpo del trabajo, es la $2^{\mathrm{a}}$ fórmula la que da luces sobre el alcance del inciso, a la vez que satisface su sentido práctico. La $1^{a}$ fórmula tenía todo sentido en el original art. 48 del proyecto de LMV (=art.53 LMV), como hipótesis comprensiva de todas las manipulaciones operativas, especialmente de las propias (transacciones reales). Que ése era su sentido resulta irrefutable si se considera que a la fórmula le seguía, en el inciso final del art. 48, una cláusula justificante de las estabilizaciones (manipulaciones operativas paradigmáticas), similar a la del actual art. 52. Pues, ¿a qué podía servir una justificante de estabilización si el art. 48 (idéntico a nuestro actual art. 53) no hubiese supuesto la tipificación de las manipulaciones operativas? Indudablemente las incluía ${ }^{169}$. Pues bien, con la sucesiva incorporación del vigente inciso $1^{\circ}$ del art. 52 LMV - que de manera más clara se hace cargo de las manipulaciones operativas propias, según hemos visto- la $1^{\mathrm{a}}$ fórmula del inciso $2^{\mathrm{o}}$ en comento perdía en gran medida su sentido autónomo. Con razón la justificante de estabilización fue cambiada de lugar, ubicándose como inciso $2^{\circ}$ del art. 52. Así, es posible afirmar hoy que la $1^{\text {a }}$

169 La hipótesis de "transacciones engañosas" evoca la fórmula anti-manipulativa del derecho federal estadounidense ya comentada: la series of transactions de la §9(a)(2) SEA1934. Detalles pueden apreciarse en LONDOÑO, “Aproximación histórico-comparada", cit. nota n 1, pp. 414 y ss. 
Polít. crim. Vol. 12, № 24 (Diciembre 2017), Art. 13, pp. 1106-1183.

[http://www.politicacriminal.cl/Vol_12/n_24/Vol12N24A13.pdf]

fórmula permite cubrir manipulaciones operativas engañosas (de injerencia indirecta) no cubiertas por el inciso $1^{\circ}$ del art. 53, ni por la amplia fórmula de inducción del inciso $2^{\circ}$.

La $2^{\text {a }}$ fórmula del inciso en comento -inducción a la compra o venta de valores- evoca innegablemente el lenguaje de la clásica §9(a)(2) SEA'34 del derecho federal estadounidense, explícitamente dedicada a la prohibición de la manipulación de los precios de valores. Esa inducción a las compras o ventas es funcional a una injerencia en la demanda (=compras) u oferta (=ventas) de los títulos respectivos, de manera idónea para condicionar los respectivos precios-de-mercado: hacia el alza o hacia la baja, según el sentido de la inducción.

La referencia a "cualquier acto, práctica, mecanismo o artificio engañoso o fraudulento" es de tipo medial y no agota el sentido de injusto de la prohibición. Es decir, esos actos, prácticas, mecanismos o artificios están prohibidos en cuanto medios o mecanismos para inducir a la compra o venta de valores, precisamente en el sentido manipulativo del preciode-mercado. Lo mismo cabe decir de las transacciones ejecutadas mediante esos actos, prácticas, mecanismos o artificios. Es decir, el sentido anti-manipulativo de la prohibición no varía en aquella fórmula, cuya existencia sólo se explica en el marco de la génesis de la LMV, en el original art. 48 del proyecto, como se ha explicado recién.

Por otra parte, descartando una interpretación que fusione los adjetivos engañoso y fraudulento bajo una sola voz (ambas como formas de engaño = tesis del pleonasmo), la adjetivización alternativa puede reconducirse a dos formas de lesividad manipulativa, general y especial, respectivamente, siempre con referencia al sistema de formación de los precios-de-mercado (y no con referencia a intereses patrimoniales acotados). Esto significa que se prohíbe no sólo aquella manipulación (fraudulenta) que aleja los precios-demercado del razonable valor de inversión (manipulación especial o distorsión), sino también aquella manipulación (engañosa) que simplemente condiciona la libre formación de los precios (manipulación general o mero control sobre los precios) ${ }^{170}$.

En fin, el objeto de las conductas del inciso presenta una importante particularidad: se trata de valores, por cierto, pero no sólo de aquellos regidos por la LMV, sino también de aquellos excluidos de su disciplina ("regidos o no por esta ley" reza la norma). ¿Por qué esa amplitud, en principio contradictoria con un interés de protección radicado en sistemas institucionalizados (regulados y confiables) de formación de los precios de los valores? La espinuda cuestión ha sido latamente tratada en el cuerpo del trabajo (cfr. supra 2.4.1.d), de modo que aquí bastará con afirmar que para los efectos del art. 53, valores no regidos por la LMV son sólo aquellos títulos aludidos en el inc. $2^{\circ}$ del art. 3 LMV; a saber, aquellos de índole estatal o públicos (= "valores emitidos o garantizados por el Estado, por las instituciones públicas centralizadas o descentralizadas y por el Banco Central de Chile"). El especial interés público en la correcta cotización de este tipo de instrumentos -cuyo éxito está enlazado al ahorro interno- justificaría esta excepción. En fin, por valores regidos por la LMV han de entenderse aquellos mencionados en el inciso $1^{\circ}$ del art. $3^{\circ}$, en el marco de

${ }^{170}$ Cfr. supra 2.4.1.a.Excurso, descartando una tercera alternativa hermenéutica, que entienda la voz "fraudulento" como sinónimo de delictivo o genéricamente ilícito. 
LONDOÑO, Fernando “¿Qué prohíben los artículos 52 y 53 de la Ley de Mercado

de Valores? Reconstrucción dogmática de las figuras de manipulación

de mercado en el derecho chileno".

una oferta pública, así como definida en el inciso $1^{\circ}$ del art. $4^{\circ}$ LMV, considerando además lo dispuesto en los arts. $1^{\circ}$ y $5^{\circ}$ de la misma ley.

\section{b) Tipo subjetivo}

Lo que se ha afirmado para el inciso $1^{\circ}$ del art. 53 cabe reiterarlo aquí, si bien reforzando los frentes de resistencia al dolo eventual, habida cuenta del sentido manipulativo de la inducción con injerencia en las fuerzas del mercado y considerando además la problemática concursal en un supuesto de colisión con el art. 61 LMV (sobre lo cual, cfr. supra 2.6).

\section{c) Justificantes especiales}

No las hay. Vale lo dicho en lo pertinente para el inciso $1^{\circ}$ del art. 53.

\section{Epílogo}

Como se ha procurado demostrar, las prohibiciones de los arts. 52 y 53 constituirían una compacta tríada de fórmulas anti-manipulativas del precio-de-mercado de títulos transados en el mercado de valores regulado por la LMV. Como tales, no están destinadas directamente a la tutela de bienes individuales-patrimoniales (que pueden igualmente aparecer colateralmente afectados en su contexto de aplicación), sino a la salvaguardia de intereses institucionales o supra-individuales: el buen funcionamiento de un sistema regulado de mercado de valores (tan decisivo macroeconómicamente por su rol de conexión del ahorro con la inversión); más concretamente, se trata aquí de resguardar la correcta formación de los precios-de-mercado y su correlativa fiabilidad.

Esta última consideración permite colocar el tratamiento del Título VIII LMV en su centro, como ya se anticipara en otro lugar ${ }^{171}$ : y es que el precio-de-mercado representa una herramienta de transparencia decisiva (porque sintética y pública) para la identificación del más probable valor de inversión de los títulos/emisores (en función de su esperada rentabilidad-futura). Apoyándose en el poder de la agregación de valoraciones singulares (de cada uno de los participantes que concurren al mercado, ofertando o demandando títulos, momento a momento), el precio-de-mercado corona una serie de estrategias e instituciones informativas (desde la exigencia basilar de revelación obligatoria prevista en los arts. $9^{\circ}$ y $10 \mathrm{LMV}$, hasta la intermediación informativa ejercida por prestadores de reputación: clasificadores de riesgo, auditoras, analistas), dirigidas todas a contener los riesgos de un escenario de asimetría informativa intolerable; es decir, los riesgos de degradación del mercado a causa de la selección adversa a que, por vía del regateo a la baja, conduce la transmisión de desconfianza de los agentes que lidian con la opacidad ${ }^{172}$.

Este epílogo -malogradamente reconcentrado en su prosa y conceptos- corre el riesgo de volverse críptico. No se me escapa aquello. Me anima sin embargo la confianza de estar simplemente recapitulando conceptos muy transitados en el amplio sector del derecho financiero-bursátil, tomando prestados los cuales desde hace ya casi un lustro quise darme a

\footnotetext{
${ }^{171}$ Cfr. LONDOÑO, "Ilícito de manipulación”, cit. nota ${ }^{\circ}$ 2, pp. 74 y ss.

${ }^{172}$ Para detalles, cfr. supra la nota $\mathrm{n}^{\mathbf{0}} 2$, a propósito de la asimetría informativa y la selección adversa.
} 
Polít. crim. Vol. 12, № 24 (Diciembre 2017), Art. 13, pp. 1106-1183.

[http://www.politicacriminal.cl/Vol_12/n_24/Vol12N24A13.pdf]

la tarea de ofrecer una taxonomía $(2013)^{173}$, un contexto normativo-comparado $(2015)^{174}$ y una interpretación sistemática (2017) para un fenómeno y unas prohibiciones tan poco atendidas en nuestro medio como, creo, relevantes. Con este tercer trabajo -ya en la fase "de bajada" de una curva abierta en $2013^{175}$ - quisiera creer que se ha completado una primera propuesta de explicación, todavía muy general, de la regulación sancionadora de la manipulación de mercado en el derecho chileno.

Pendiente queda todavía un tratamiento monográfico de aspectos como la situación de las manipulaciones operativas propias (y su problemática distinción, sustantiva y probatoria, respecto de las operaciones lícitas), así como la precisa conexión entre las figuras que aquí nos han ocupado y las varias (y no siempre claras) formas de falsedad de que trata el artículo $59 \mathrm{LMV}^{176}$. Que para ello sea propicio el futuro.

${ }^{173}$ LONDOÑO, "Ilícito de manipulación”, cit. nota $n^{\circ} 2$.

${ }^{174}$ LONDOÑO, "Aproximación histórico-comparada", cit. nota $\mathrm{n}^{\circ} 1$.

175 "De bajada" en el sentido de "aterrizaje práctico" y no de "declive" o "decadencia", espero.

${ }^{176}$ De especial interés en este contexto, cfr. HERNÁNDEZ, "La necesaria relevancia", cit. nota ${ }^{\circ}$ 67. Para una visión general sobre el art. 59 LMV, cfr. también el ya citado GARCÍA, "Equivalentes funcionales", cit.

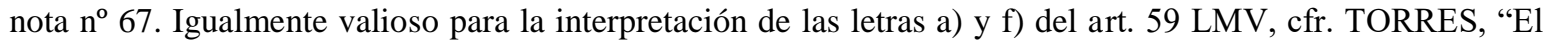
delito de entrega", cit. nota $\mathrm{n}^{\circ} 143$. Con alcance general, relativo a los delitos de falsedad contable, de interés también VARELA, Luis, "Delitos contables mercantiles en el Derecho penal económico chileno: Sistematización de su marco regulatorio, elementos comunes de sus tipos penales y desafíos pendientes". Polít. crim. Vol. 11, $\mathrm{N}^{\mathrm{o}} 21$ (Julio 2016), Art. 10, pp. 264-306, disponible en: http://www.politicacriminal.cl/Vol_11/n_21/Vol11N21A10.pdf. En lo demás, tomas de posición parciales y provisorias respecto a las letras a) y f) del art. 59 LMV figuran ya en el presente trabajo: supra nota $\mathrm{n}^{\circ}$ 67, supra 2.4.1.d) [hacia el final, nota al pie $\mathrm{n}^{\mathrm{o}}$ 143] y supra 2.4.2.c) [también hacia el final]. 
LONDOÑO, Fernando “¿Qué prohíben los artículos 52 y 53 de la Ley de Mercado de Valores? Reconstrucción dogmática de las figuras de manipulación de mercado en el derecho chileno".

\section{BIBLIOGRAFIA}

AKERLOF, George, "The Market for «Lemons»: Quality Uncertainty and the Market Mechanism", Q. J. Econ., Vol. 84 (1970), pp. 488-500.

ALLEN, Franklin; GALE, Douglas, "Stock-Price Manipulation”, Rev. Fin. Stud. (1992), n. 5, pp. 503-529.

ANDROPHY, Joel M., White Collar Crime, Saint Paul, Minnesota: Thomson Reuters, $2^{\text {nd }}$. Ed., Vol. 2, 2011 (actualización periódica a 2016), §12.47, 12-87 y 12-88.

ARMOUR, John; AWREY, Dan; DAVIES, Paul; ENRIQUES, Luca; GORDON, Jeffrey N.; MAYER, Colin; PAYNE, Jennifer, Principles of Financial Regulation, New York: Oxford University Press, 2016.

AVGOULEAS, Emilios, The Mechanics and Regulation of Market Abuse. A legal and Economic Analysis, Oxford: Oxford University Press, 2005.

BERLE, Adolf. A., "Stock Market Manipulation", Colum. L. Rev., n. 38 (1938), pp. 393 y sS.

BUDNEVICH, Carlos y ZURITA, Salvador, "Diagnóstico, Evaluación y Propuesta de Desarrollo del Mercado de Derivados en Chile", febrero de 2010, pp. 64 y ss., especialmente pp. 71-72 y 84, disponible en: http://www.svs.cl/portal/publicaciones/610/w3-article-15011.html.

COX, James D., HILlMAN, Robert W., LANGEVOORT, Donald C., Securities Regulation. Cases and Materiales, New York: Wolters Kluwer, 8th ed., 2016.

ESTRADA, Albert, "Presente y futuro del delito de alteración de precios (art. $284 \mathrm{Cp}$ )", InDret, $1 / 2014$.

ETCHEBERRY, Alfredo, Derecho Penal. Parte Especial, Tomo IV, $3^{\text {a }}$ ed., Santiago: Editorial Jurídica de Chile, 1998.

GARCÍA, Gonzalo, "La idealización y la administrativización de la punibilidad del uso de Información Privilegiada. Un análisis de los discursos penales en la doctrina chilena", Polít. crim. Vol. 10, No 19 (Julio 2015), Art. 5, pp. 119-158, p. 151, en http://www.politicacriminal.cl/Vol_10/n_19/Vol10N19A5.pdf

, "Equivalentes funcionales en los delitos económicos. Una aproximación de solución ante la falta de lesividad material en delitos de presentación de información falsa al mercado de valores", Polít. crim. Vol. 12, No 23 (Julio 2017), Art. 6, pp. 151206, en: http://www.politicacriminal.cl/Vol_12/n_23/Vol12N23A6.pdf

GARRIDO, Mario, Derecho Penal. Parte Especial, T. IV, $2^{\mathrm{a}}$ Ed., Santiago: Ed. Jurídica de Chile, 2000, pp. 315 y ss.

GREEN, Stuart P., Lying, Cheating and Stealing, A Moral Theory of White-Collar Crime, Oxford: Oxford University Press, 2006.

HAZEN, Thomas Lee, Securities Regulation. In a nutshell, St. Paul (MN): West (Thomson Reuters), $10^{\text {th }}$ ed., 2009.

HERNÁNDEZ, Héctor, “Aproximación a la problemática de la estafa. Problemas actuales de Derecho Penal", en: AAVV., Problemas actuales en Derecho Penal, Temuco: Universidad Católica de Temuco, 2003, pp. 147-190.

, "La punibilidad de la colusión (secreta) de precios en el derecho chileno".

Polit. crim. Vol. 7, $\mathrm{N}^{\circ}$ 13, pp. 147-167, en: http://www.politicacriminal.cl/Vol_07/n_13/Vol7N13A4.pdf. 
Polít. crim. Vol. 12, № 24 (Diciembre 2017), Art. 13, pp. 1106-1183.

[http://www.politicacriminal.cl/Vol_12/n_24/Vol12N24A13.pdf]

"La necesaria relevancia para el precio de los valores de la información falsa del art. 59 letra a) de la Ley de Mercado de Valores", Revista de Derecho de la Pontificia Universidad Católica de Valparaíso XLVIII (Valparaíso, Chile, 1er semestre de 2017), pp. 105-131.

KLEIN, William A., COFFEE Jr., John C. \& PARTNOY, Frank, Business Organization and Finance. Legal and Economic Principles, New York: Foundation Press, 11th. ed., 2010.

LONDOÑO, Fernando, "Ilícito de manipulación bursátil: fenómeno y lesividad. Aspectos de política sancionatoria", Polít. crim. Vol. 8, No 15 (2013), Art. 3, pp. 64 - 127, en: http://www.politicacriminal.cl/Vol_08/n_15/Vol8N15A3.pdf.

, "Aproximación histórico-comparada al Título VIII de la Ley de Mercado de Valores: bases para el reconocimiento de un contenido anti-manipulativo", Polít. crim. Vol. 10, No 20 (2015), Art. 1, pp. 390-467.

LOSS, Louis; SELIGMAN, Joel; PAREDES, Troy, Fundamentals of Securities Regulation, New York: Wolters Kluwer, 6th. ed., 2011 (con suplemento de actualización de 2017).

MANRÍQUEZ R., Juan Carlos, "Responsabilidad penal por el producto financiero defectuoso. Especial referencia a la creación, colocación en el mercado, gestión de asesoramiento e intermediación de PFD como formas de intervención criminal", en Revista de Ciencias Penales, Sexta Época, Vol. XLII, N³ (2015), pp. 75-86.

MARKHAM, Jerry W., Law Enforcement and the History of Financial Market Manipulation, New York: Routledge, 2015.

MATUS, Jean Pierre, "Acerca de la actual falta de punibilidad en Chile de los acuerdos de precios". Polít. crim. Vol. 7, No 14 (Diciembre 2012), Art. 3, pp. 318 - 356, en: http://www.politicacriminal.cl/Vol_07/n_14/Vol7N14A3.pdf

, "De nuevo sobre la falta de punibilidad de los atentados contra la libre competencia, de conformidad con el Art. 285 del Código penal. Algunos aspectos de la discusión con Héctor Hernández" en Política Criminal”, Polít. crim. Vol. 8, No 15 (Julio 2013), Doc. 1, pp. 314-362, en: http://www.politicacriminal.cl/Vol_08/n_15/Vol8N15D1.pdf

MERA, Jorge, Fraude civil y penal. El delito de entrega fraudulenta, Santiago: Conosur, $2^{\mathrm{a}}$ Ed., 1994.

MOLONEY, Niamh, EU Securities and Financial Markets Regulation, Oxford: Oxford University Press, 3d. ed., 2014.

PARK, James J., "Reassessing the Distinction Between Corporate and Securities Law", UCLA L. Review, Vol. 64, Nm. 1 (2017), pp. 116-182.

"Delaware and Santa Fe"(April 5, 2017), en: Delaware's Dominance in Corporate Law (Cambridge University Press, de próxima publicación), UCLA School of Law, Law-Econ Research Paper No. 17-06. (Disponible en SSRN: https://ssrn.com/abstract=2947225).

PEDRAZZI, Cesare, "Turbativa dei mercati” (voce), Dig.Disc. Pen. (1999), pp. 421-432.

PERDUE, Wendy C., "Manipulation of futures markets: redefining the offense", Fordham L. Rev., n. 56 (1987), pp. 345 y ss.

PERRONE, Andrea, Il diritto del mercato dei capitali, Milano: Giuffrè Editore, 2016. 
LONDOÑO, Fernando “¿Qué prohíben los artículos 52 y 53 de la Ley de Mercado de Valores? Reconstrucción dogmática de las figuras de manipulación de mercado en el derecho chileno".

PIÑA, Juan Ignacio, "Algunos problemas del delito de uso de información privilegiada", en: GONZÁLEZ ITURRIA, Marco (Ed.), Regulaciones del Mercado de Valores, Cuadernos de Extensión jurídica, N 19, U. Andes, Santiago, 2010, pp. 113 y ss.

ROSAS, Juan Ignacio, "El delito de abuso de información privilegiada en el mercado de valores: análisis crítico de la regulación contenida en la Ley N. 18.045", Gaceta Jurídica N. 299 (2005), pp. 7-24.

ROSENBLUT, Verónica, "El denominado caso 'Schwager': análisis de histórica condena por uso de información privilegiada y manipulación bursátil”, Revista Jurídica del Ministerio Público, N. 46 (marzo 2011), pp. 185-209.

SALAH, María Agnes, Responsabilidad por uso de información privilegiada en el mercado de valores, Santiago: Lexis Nexis, 2004.

SALAZAR, Andrés. "La alteración de precios como fraude. Comentarios acerca del origen histórico del artículo 285 del Código Penal chileno y su interpretación". Polít. crim. Vol. 11, No 22 (Diciembre 2016), Art. 3, pp. 391-438, en: http://www.politicacriminal.cl/Vol_11/n_22/Vol11N22A3.pdf.

SEMINARA, Sergio, "I reati di aggiotaggio", en: PEDRAZZI, Cesare; ALESSANDRI, Alberto; FOFFANI, Luigi; SEMINARA, Sergio; SPAGNOLO, Giuseppe, Manuale di diritto penale dell'impresa, Bologna: Monduzzi, 2000, pp. 635-663.

, "Falso in prospetto", en: ALESSANDRI, Alberto (a cura di), Il nuovo diritto penale delle società, Lavis: IPSOA, 2002, pp. 201 y ss.

STEINBERG, Marc I., Understanding Securities Law, $5^{\text {th }}$ ed., New Providence: Lexis Nexis, 2009.

SWAN, Edward J. \& VIRGO, John, Market Abuse Regulation, Oxford: Oxford University Press, 2d. Ed., 2010.

THEL, Steve, "\$ 850,000 in Six Minutes -- The Mechanics of Securities Manipulation", Cornell L. Rev., n.79 (1994), pp. 219 y ss.

"The Original Conception of Section 10(b) of The Securities Exchange Act", Stan. L. Rev., vol. 42 (1989-1990), pp. 3885 y ss.

TIEDEMANN, Klaus, Wirtschaftsstrafrecht: Besonderer Teil, Köln: Heymanns, 2006 (en castellano, trad.de la 2da. edición alemana: TIEDEMANN, Klaus, Manual de Derecho Penal Económico. Parte General y Especial, Valencia: Tirant Lo Blanch, 2010).

TORRES, Angélica, "El delito de entrega de información falsa al mercado como delito base o precedente de lavado de dinero", Revista Jurídica del Ministerio Público, N. 64 (septiembre 2015), pp. 199-223.

VARELA, Luis. "Delitos contables mercantiles en el Derecho penal económico chileno: Sistematización de su marco regulatorio, elementos comunes de sus tipos penales y desafíos pendientes". Polít. crim. Vol. 11, No 21 (Julio 2016), Art. 10, pp. 264-306, en: http://www.politicacriminal.cl/Vol_11/n_21/Vol11N21A10.pdf.

VOGEL, Joachim, $\$ \$ 20 a, 38-40 b$ (kommentar), en: ASSMANN, H.D.; SCHNEIDER, U.H., Wertpapierhandelsgesetz Kommentar, Köln: Otto Schmidt, 2006, pp. 727 y ss. y 1669 y ss.

WINTER, Jaime, "Panorama del Derecho Penal Empresarial en Chile", en AMBOS, Kai et Al (Coords.), Reformas Penales, Santiago: Der Ediciones, 2017, pp. 87-119. 